obezbedio

autor

Rad je deo istraživanja na projektu 179065 Ministarstva prosvete, nauke i tehnološkog razvoja Republike Srbije „Uloga države u novom modelu rasta privrede Srbije”.

\title{
Rezime
}

U ovom radu se istražuje povezanost salda tekućeg računa perifernih članica evrozone (Italija, Španija, Portugalija, Irska i Grčka) sa glavnim determinantama koje ga opredeljuju u periodu 20002017. godine. Istraživanje je sprovedeno metodologijom panela. Saldo tekućeg računa je zavisna varijabla, a set izabranih relevantnih objašnjavajućih makroekonomskih veličina predstavlja regresore panela. Pošto su panel vremenske serije posedovale jedinični koren, sprovedeni su testovi kointegracije. S obzirom da su rezultati ovih testova potvrdili postojanje kointegracije između vremenskih serija panela, pristupilo se oceni kointegracione regresione jednačine. Za ovu ocenu primenjeni su FMOLS i DOLS estimatori. Ocenjeni koeficijenti kointegracionih regresora pomoću FMOLS estimatora su statistički signifikantni za celo razdoblje 2000-2017. godine. Jedini izuzetak na nivou polaze jednačine je FMOLS ocena parametra uz doznake, koja nije statistički signifikantna. U slučaju primene DOLS estimatora, nekoliko ocenjenih parametara nije pokazalo signifikantnost. Znaci ispred ocena parametara uglavnom se slažu sa teorijskim pristupom. Ocenjeni parametri pokazuju dugoročnu usklađenost kretanja salda tekućeg računa i izabranih makroekonomskih regresora. Dobijeni nalazi su potvrili perzistentnost salda tekućeg računa perifernih članica evrozone.

Ključne reči: tekući račun, periferne članice evrozone, kointegracija, test jediničnog korena u kointegraciji, realni efektivni devizni kurs, neto inostrana aktiva, strane direktne investicije 


\section{CURRENT ACCOUNT IN THE PERIPHERIAL MEMBERS OF THE EUROPEAN UNION - PANEL ANALYSIS}

Radovan Kovačević

Faculty of Economics, Belgrade radovank@ekof.bg.ac.rs

This paper is part of the project no. 179065 "The Role of the State in the New Model of Economic Growth in Serbia", financed by the Ministry of Education, Science and Technological Development of the Republic of Serbia

\section{Summary}

This paper examines the correlation between the current account balance of peripheral eurozone members (Italy, Spain, Portugal, Ireland and Greece) and the main determinants that define it for the period 2000-2017. The research was carried out by means of panel methodology. The current account balance is a dependent variable, and a set of selected relevant explanatory macroeconomic variables represents the panel regressors. Since the panel time series had a single root, cointegration tests were conducted. Since the results of these tests confirmed the existence of cointegration between the panel time series, the cointegration regression equation was estimated. For this assessment, FMOLS and DOLS estimators were applied. The estimated coefficients of cointegration regressors using FMOLS estimators are statistically significant for the entire period 2000-2017. The only exception at the level of the starting equation is the FMOLS estimation of the parameter with remittances, which is not statistically significant. In the case of the application of the DOLS estimator, several estimated parameters did not show significance. The signs in front of the parameter estimates generally agree with the theoretical approach. The estimated parameters show long-term compliance of the current account balance and selected macroeconomic regressors. The obtained findings confirm the persistence of the current account balance in peripheral eurozone members.

Key words: current account, peripheral eurozone members, cointegration, unit root test, real effective exchange rate, net foreign assets, foreign direct investment 


\section{Uvod}

Posle uvođenja evra usledio je period širenja deficita perifernih članica evrozone. U grupu jezgra evrozone u ovom radu spadaju Nemačka, Francuska, Holandija, Belgija, Austrija i Finska, a u grupu perifernih članica Italija, Španija, Portugalija, Irska i Grčka. Grčka i Portugalija su imale veliki deficit tekućeg računa u vreme uvođenja evra, Španija je imala manji deficit, dok je Irska imala uravnotežen bilans. Posle uvođenja evra došlo je do pogoršanja salda tekućeg računa kod svih perifernih članica evrozone, izuzev Portugalije gde se zadržao na nivou ulaska u evrozonu. Ovakvo stanje je dokumentovano $\mathrm{u}$ brojnim analizama (na primer, Berger and Nitsch, 2010; Jaumotte and Sodsriwiboon, 2010). U ovim studijama se ističe da je veliki priliv stranog kapitala podstakao domaću tražnju, što je izazvalo porast uvoza i širenje deficita tekućeg računa. Rastuća globalna likvidnost je olakšala zaduživanje perifernih članica. Neravnoteža javnog sektora u Grčkoj i Portugaliji pre izbijanja svetske ekonomske krize 2008. godine bila je glavni uzročnik širenja deficita tekućeg računa.

Perzistentnost deficita tekućeg računa perifernih članica evrozone $u$ literaturi se objašnjava na različite načine. Smanjena konkurentnost usled viših troškova rada i neproduktivne investicije najčešće se navode kao razlozi ove pojave. Blanchard and Giavazzi (2002) smatraju da je znatno opala korelacija između nacionalne štednje $\mathrm{i}$ investicije $\mathrm{u}$ periodu posle uvođenja evra. Mada neoklasična ekonomija ističe da bi na integrisanom tržištu kapitala trebalo da nastupi automatsko rebalansiranje salda tekućeg računa, to se u slučaju perifernih članica evrozone nije desilo. Cesaroni and De Santis (2015) su analizirale dualizam u kretanju deficita tekućeg računa između perifernih članica i jezgra evrozone, fokusirajući se na ulogu procesa evropske finansijske integracije. Autorke ovog rada su zaključile da je finansijska integracija imala važnu ulogu u objašnjenju dinamike tekućeg računa zemalja Evropske unije. Takođe su prezentirale dokaze o nepovolinom uticaju finansijske integracije na periferne članice evrozone. Negativna korelacija između finansijske integracije i tekućeg računa se, po nalazima ovih autora, uvećala posle uvođenja evra.

U ovom radu se istražuju determinante bilansa tekućeg računa perifernih članica evrozone. Rad doprinosi postojećoj literaturi na tri načina. Prvo, u njemu je sadržana empirijska analiza determinanti bilansa tekućeg računa perifernih članica evrozone u celom razdoblju 2000-2017. godine, kao i u dva potperioda jedan je do izbijanja krize (2000-2007), a drugi posle krize (2008-2017). Drugo, u radu se koristi panel regresiona analiza, koja uključuje brojne regresore $\mathrm{i}$ ocenjuje njihov uticaj na saldo tekućeg računa. Na kraju, da bi se ocenila uloga upravljanja i kvaliteta institucija na neravnotežu tekućeg računa, $\mathrm{u}$ analizu je uključen i regresor koji reprezentuje kvalitativne varijable.

Rad je organizovan na sledeći način. U drugom delu se iznose stilizovane činjenice koje se odnose na neravnotežu tekućeg računa perifernih članica evrozone. U trećem delu se opisuju izvori podataka i vremenski okviri analize, dok se u četvrtom delu skicira empirijska strategija istraživanja. U petom delu se izlažu empirijski rezultati i diskusija, uz proveru robustnosti.

\section{Stilizovane činjenice}

Dokazi o divergentnom kretanju salda tekućeg računa između zemalja koje čine jezgro evrozone i perifernih članica su brojni. Deficit tekućeg računa perifernih članica se uvećavao od 2000. do 2008. godine, dok su članice jezgra ostvarivale suficite (slika 1). Najveći deficit tekućeg računa, kao procenat bruto domaćeg proizvoda (eng. gross domestic product GDP) u vreme izbijanja krize 2008. imale su Grčka (15\%) i Portugalija (12\%). Primena odgovarajućih mera ekonomske politike, kao odgovor na svetsku ekonomsku krizu iz 2008. godine i krizu državnih dugova evrozone, dovela je do smanjivanja ovog raskoraka. 


\section{Introduction}

The introduction of the euro was followed by the period of deficit expansion in the peripheral eurozone members. In this paper, the core of the eurozone will include Germany, France, the Netherlands, Belgium, Austria and Finland, and the group of peripheral members will include Italy, Spain, Portugal, Ireland and Greece. Greece and Portugal had a large current account deficit at the time of the introduction of the euro, Spain had a smaller deficit, while Ireland had a balance equilibrium. After the introduction of the euro, the current account balance deteriorated in the all peripheral eurozone members, except for Portugal, where it remained at the level of entry into the eurozone. This is documented in numerous analyzes (for example, Berger and Nitsch, 2010; Jaumotte and Sodsriwiboon, 2010). These studies point out that a large inflow of foreign capital spurred domestic demand, which caused an increase in imports and widening of the current account deficit. The increase in global liquidity facilitated the borrowing of peripheral members. The imbalance of the public sector in Greece and Portugal before the outbreak of the global economic crisis in 2008 was the main cause of the current account deficit growth.

The persistence of the current account deficit for the eurozone members is explained in different ways in reference literature. Reduced competitiveness due to higher labor costs and nonproductive investments are most often referred to as the reasons for this phenomenon. Blanchard and Giavazzi (2002) consider that the correlation between national savings and investment in the period after the introduction of the euro significantly dropped. Although the neoclassical economics emphasizes that an automatic rebalancing of the current account balance should occur on the integrated capital market, this has not happened in the case of peripheral members of the eurozone. Cesaroni and De Santis (2015) analyzed dualism in the movement of the current account deficit between peripheral members and the core of the eurozone, focusing on the role of the European financial integration process. The authors of this paper concluded that financial integration had an important role in explaining the dynamics of the current account in the European
Union countries. They also presented evidence of the adverse impact of financial integration on the peripheral eurozone members. The negative correlation between financial integration and current account, according to the findings of these authors, increased after the introduction of the euro.

This paper examines the determinants of the current account balance in peripheral eurozone members. The paper contributes to the existing literature in three ways. First, it contains an empirical analysis of the determinants of the current account balance in the peripheral eurozone members throughout the period 2000-2017, as well as in two subperiods - one until the outbreak of the crisis (2000-2007) and another after the crisis (2008-2017). Second, the paper uses the panel regression analysis, which includes numerous regressors and estimates their impact on the current account balance. In the end, in order to assess the role of management and quality of institutions in relation to the current account imbalance, the analysis also includes a regressor representing qualitative variables.

The paper is organized in the following way. The second part presents stylized facts concerning the imbalance of the current account in the peripheral eurozone members. The third part describes the sources of data and the time frame of the analysis, while the fourth part draws on the empirical research strategy. In the fifth part, empirical results and discussion are exposed, along with the robustness test.

\section{Stylized Facts}

The evidence of the divergent developments in the current account balance between the countries that form the core of the eurozone and the peripheral members are numerous. The current account deficits of peripheral members increased from 2000 to 2008, while the core members realized surpluses (Figure 1). The largest current account deficit, as a percentage of gross domestic product (GDP) at the time of the crisis in 2008, was recorded by Greece $(15 \%)$ and Portugal (12\%). The application of appropriate economic policy measures, in response to the 2008 global economic crisis and the eurozone debt crisis, has led to a shrinking of this gap. 
Slika 1. Saldo tekućeg računa „jezgra“ evrozone i perifernih članica - aritmetički prosek ( $\mathrm{u}$ \% od GDP-a)

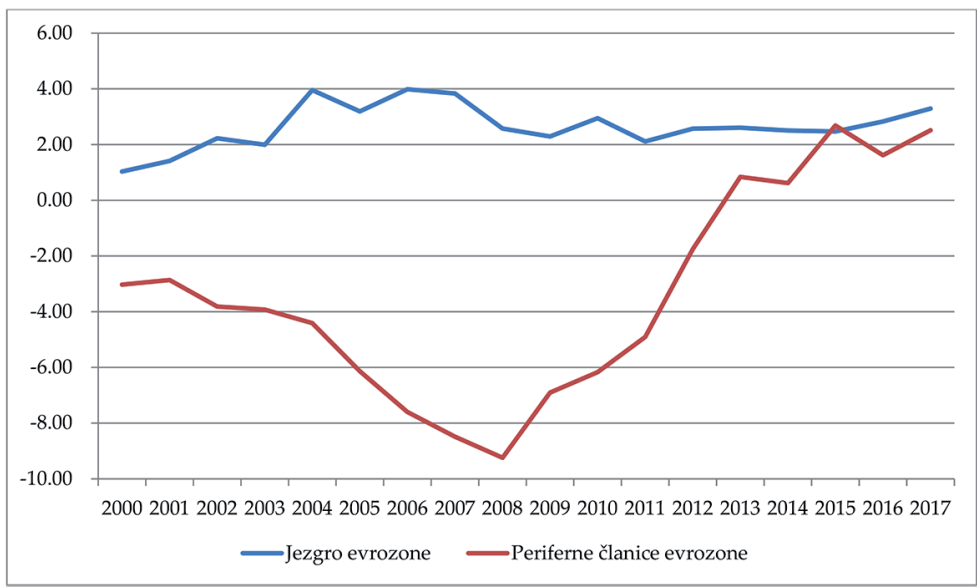

Izvor: OECD, https://stats.oecd.org/\# Pristupljeno 15.11.2018. tekućeg računa perifernih članica evrozone, pri čemu je najmanje pogoršanje imala Italija, a najveće Grčka. Naravno, nije moguće tvrditi da je uvođenje evra doprunelo širenju ovog deficita, već su na to uticali i drugi faktori. Pogoršanje salda tekućeg računa je ostvareno i u zemljama izvan evrozone - Danska, Švedska i Velika Britanija. Posle izbijanja finansijske krize 2008. u perifernim članicama evrozone, a i zemljama izvan ove zone, nastupila je redukcija deficita tekućeg računa (Atoyan et al. 2013).

Strukturno prilagođavanje privrede evrozone $\mathrm{u}$ razdoblju posle 2009. godine uticalo je na smanjivanje deficita tekućeg računa perifernih članica, a od 2013. godine kod ovih zemalja se registruje agregatni suficit (slika 2). Najsporija dinamika prilagođavanja tekućeg računa posle 2008. zapaža se kod Grčke i Portugalije. Kompozicija prilagođavanja se takođe razlikuje između zemalja. Redukcija uvoza perifernih članica uticala je na smanjivanje deficita tekućeg računa ovih zemalja. Lošije izvozne

Slika 2. Bilans tekućeg računa perifernih članica evrozone pregled po zemljama, u \% GDP-a

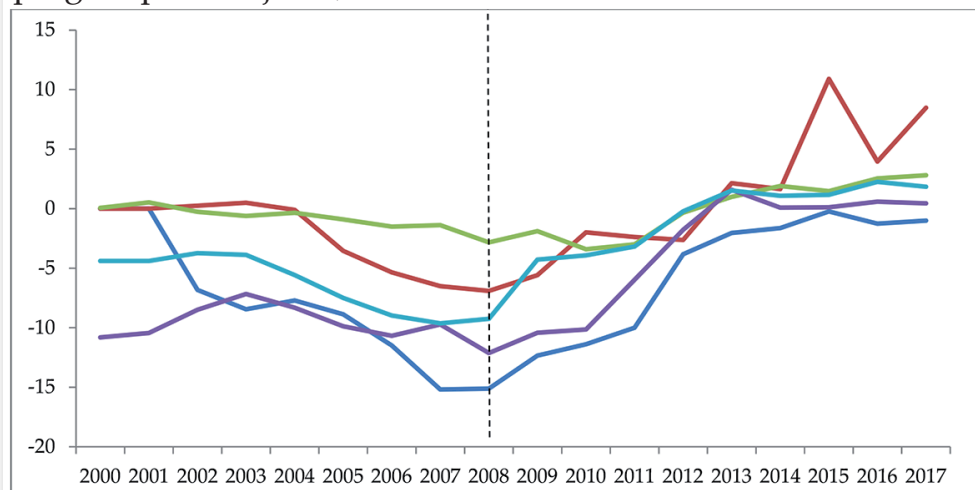

-Grčka -Irska -Italija —Portugalija —Španija

Izvor: OECD, https://stats.oecd.org/\# Pristupljeno 15.11.2018. performanse perifernih članica evrozone, koje imaju značajnu međusobnu trgovinu, povezane su sa slabijom uvoznom tražnjom partnerskih zemalja. Raspoloživost finansiranja takođe delom utiče na slabiju uvoznu tražnju perifernih članica. Nivo zaduženosti, posebno domaćinstava, naglašen je u perifernim članicama.

Kretanje kapitala unutar evrozone omogućilo je finansiranje javnog duga u Grčkoj, kupovinu nekretnina u Španiji i Irskoj, dok su u Portugaliji i Italiji primenjivana oba modela. Ovakva struktura tokova kapitala pokazuje da su investitori smatrali da su hartije od vrednosti perifernih članica evrozone bliski suspstituti hartija od vrednosti koje emituju zemlje jezgra evrozone. Prema slici 2. uočava se da je posle uvođenja evra sve do izbijanja svetske ekonomske krize 2008. godine porasla perzistentnost deficita
Globalna finansijska kriza 2007-2008. značajno je uticala na tokove kapitala. Periferene članice nisu bile odmah pogođene ovom krizom, ali je 2010. došlo do naglog prekida tokova privatnog kapitala, što je pojačalo krizu javnih dugova nekih zemalja. Pogoršan je kreditni rejting Irske, Grčke i Portugalije, uz porast spredova na njihov javni dug $\mathrm{u}$ odnosu na javni dug Nemačke. Prilagođavanje njihovog tekućeg računa nije bilo moguće pomoću depresijacije, jer su one članice evrozone. Zbog toga su ove zemlje nastavile da beleže deficit tekućeg računa, ali u manjim razmerama. Zahvaljujući velikim pozajmicama njihovih centralnih banaka od Evropske centralne banke (ECB) putem mreže poznate kao "Evrosistem Target2", ove zemlje su nadoknadile smanjeni priliv privatnog kapitala. Time su izbegle 
Figure 1. Current account balance of the eurozone Core and Periphery - arithmetic average (\% GDP)

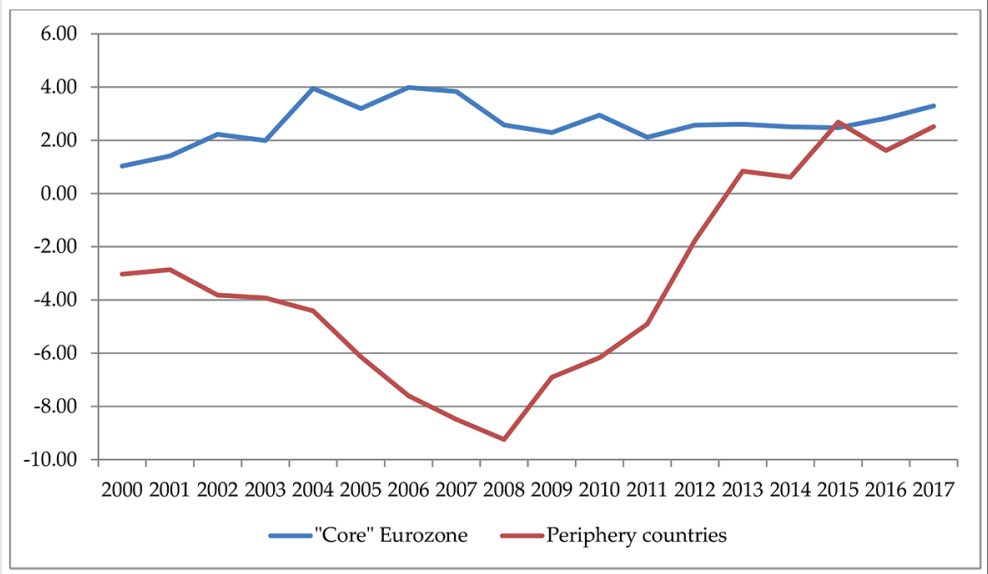

Source: OECD, https://stats.oecd.org/\# Accessed 15.11.2018

Structural adjustment of the eurozone in the period after 2009 influenced the reduction of the current account deficit in peripheral members, and since 2013, an aggregate surplus is registered in these countries (Figure 2). The slowest dynamics of the adjustment of the current account after 2008 is observed in Greece and Portugal. The adjustment composition also varies between countries. A reduction of imports of peripheral members influenced the reduction in the current account deficit of these countries. The poorer export performance of peripheral eurozone members, which have significant trade with each other, is associated with the weaker demand of

Figure 2. The current account balance in peripheral eurozone members - overview of countries, in \% GDP

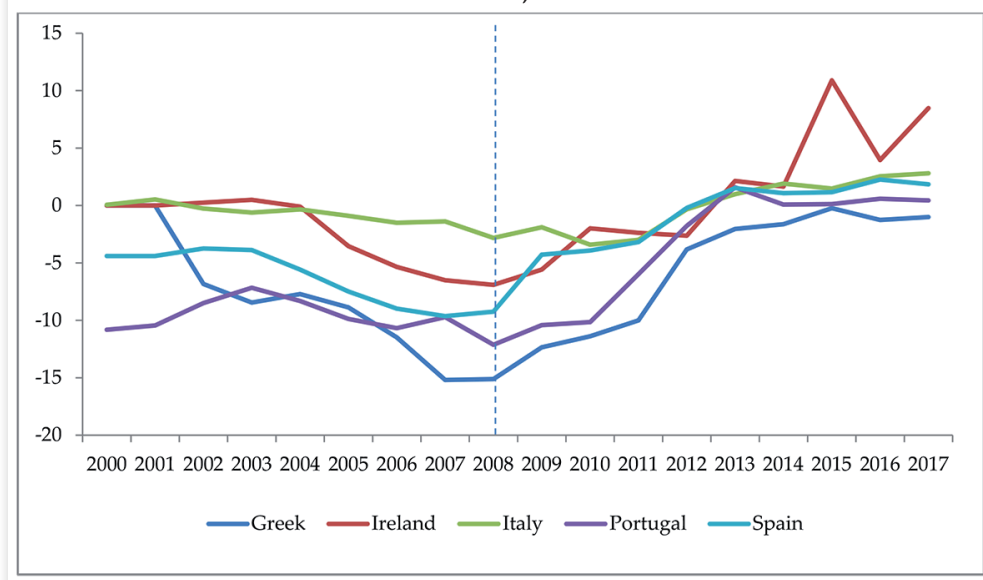

Source: OECD, https://stats.oecd.org/\# Accessed 15.11.2018 partner countries. The availability of funding also partly affects the lower import demand of peripheral members. The level of indebtedness, particularly households, is emphasized in peripheral members.

The capital flows within the eurozone enabled the financing of public debt in Greece, the purchase of real estate in Spain and Ireland, while both models were applied in Portugal and Italy. This structure of capital flows shows that investors believed that the securities of the peripheral eurozone members are close substitutes for the securities issued by the countries of the eurozone core. According to Figure 2, after the introduction of the euro until the outbreak of the global economic crisis, the persistence of the current account deficit in the peripheral eurozone members increased in 2008, with the slightest deterioration in Italy, and the highest in Greece. Of course, it is impossible to claim that the introduction of the euro contributed to the increase of this deficit, but other factors also affected it. The deterioration of also recorded in the countries outside the euro area - Denmark, Sweden and the United Kingdom. After the outbreak of the financial crisis in 2008, there was a reduction in the current account deficit of the peripheral eurozone countries and countries outside this zone (Atoyan et al., 2013). the current account balance was 
platnobilansnu krizu, ali su morale da pristupe postepenom rebalansiranju tekućeg računa. Povećanje izvozne konkurentnosti ovih zemalja zahteva smanjenje njihovih nadnica u odnosu na nemačke. Olakšavajuća okolnost je to što posredstvom sistema Target2 mogu da svoj tekući račun prilagođavaju postepeno, u uslovima krize javnog duga.

\section{Pregled literature}

Literatura koja istražuje dinamiku salda tekućeg računa $\mathrm{u}$ perifernim članicama evrozone je brojna, i uglavnom se odnosi na period pre izbijanja krize 2008. godine. Istraživanja kretanja salda tekućeg računa navode brojne razloge za pojavu neravnoteže unutar evrozone. Jedna grupa autora snatra da odgovor na ovo pitanje leži na području finansiranja i zaključuje da je veliki priliv kapitala $u$ periferne zemlje glavni uzročnik velikih neravnoteža tekućeg računa. Drugi smatraju da je gubitak spoljne konkurentnosti vodeći razlog za formiranje neravnoteža.

Chinn i Ito (2008) su u analizi determinanti tekućeg računa posebno naglasili ulogu finansijskog razvoja i institucija. Kao pokazatelj finansijskog razvoja koristili su koeficijent privatni krediti/BDP na uzorku od 70 zemalja u razvoju i 19 razvijenih zemalja, u periodu 19712004. godine. Utvrdili su negativan uticaj ovog pokazatelja na tekući račun kako razvijenih tako i zemalja u razvoju.

Jaumotte and Sodsriwiboon (2010) su primenili panel analizu na uzorku od 49 razvijenih zemalja (uključujući 27 članica Evropske unije) i zemalja sa tržištem u nastajanju, za period 1973-2008. godine. Ovi autori su utvrdili da finansijska otvorenost smanjuje agregatni saldo tekućeg računa, ali nisu posmatrali odvojeno uticaj finansijske integracije na zemlje jezgra i periferije.

Za razliku od prethodnog nalaza, Kentsch (2010) je došao do zaključka da su neravnoteže tekućeg računa unutar evrozone uglavnom nastale usled raskoraka u izvoznim performansama između periferije i jezgra. Ovaj nalaz se posebno odnosi na period posle 2003. kad se uvoz razvijao sličnom dinamikom širom evrozone. Zaključak ovog istraživanja je da su neravnoteže tekućeg računa nastale više zbog gubitka izvozne konkurentnosti nego zbog obilnog priliva kapitala do koga je došlo usled finansijske integracije.

Ahearne et al. (2007) i Schmitz and von Hagen (2011) su koristili podatke o per capita dohotku kao aproksimaciju finansijske dubine i na primeru EU 15 su utvrdili da su neto tokovi sledili razlike u dohotku, čak i pre uvođenja evra. Njihova ekonometrijska istraživanja su potvrdila postojanje razlika u finansijskoj dubini evropskih tržišta kapitala, i da se kapital kretao iz zemlja gde je on obilan faktor proizvodnje $u$ zemlje gde je bio redak faktor.

Belke and Dreger (2013) su poredili efekte razlika per capita dohotka i konkurentnosti na tekući račun, koristeći panel kointegraciju za 11 članica evrozone u različitim potperiodima. Primenom ovog metoda, ovi autori su zaključili da su razlike $\mathrm{u}$ konkurentnosti bile glavni faktor eksternih neravnoteža evrozone. U odvojenoj regresiji za Grčku, Španiju i Portugaliju autori su ukazali na opadajuću ulogu per capita dohotka (ova varijabla je korišćena kao zamena za sustizanje) za ove zemlje tokom vremena. Da bi se reducirao deficit tekućeg računa ovih zemalja, u radu je preporučena depresijacija deviznog kursa.

Sanchez and Varoudakis (2013) su ispitivali uticaj odabranih makroekonomskih faktora na neravnotežu tekućeg računa u evrozoni. Ovi autori su primenili vektorski autoregresioni model na panel podacima za period 19752011. godine, pri čemu nisu posmatrali uticaj finansijske integracije. $\mathrm{Na}$ osnovu nalaza ovog modela, autori su zaključili da su šokovi tražnje više uticali na dinamiku tekućeg računa perifernih članica evrozone nego na članice jezgra, dok je konkurentnost imala slabiju ulogu kod perifernih članica, odnosno jaču ulogu kod zemalja jezgra.

Schmitz and von Hagen (2011) su istraživali uzroke neravnoteža tekućeg računa unutar evrozone i došli do zaključka da su razlike u per capita dohotku između periferije i jezgra bile ključni činilac koji je doveo do privlačenja stranog kapitala i do širenja deficita tekućeg računa. Takođe su ocenili da su razlike u dohotku pojačale uticaj na neravnotežu tekućeg računa unutar evrozone posle uvođenja evra. Na neravnoteže sa partnerima izvan EU uticala je, po mišljenju ovih autora, apresijacija evra u 
central bank borrowings from the European Central Bank (ECB) through a network known as the "Eurosystem Target2", these countries have compensated for the reduced inflow of private capital. In this way they avoided the balance of payments crisis, but they had to approach a gradual rebalancing of the current account. The increase of export competitiveness of these countries requires the lowering of their wages against the German's. The mitigating circumstance is that through the Target2 system they can adjust their current account gradually, in the context of the public debt crisis.

\section{Literature Review}

The literature examining the dynamics of the current account balance in peripheral eurozone members is abundant, and mainly refers to the period before the outbreak of the 2008 crisis. The research of the current account developments cites a number of reasons for the imbalance in the eurozone. One group of authors considers that the answer to this question lies in the field of financing and concludes that a large capital inflow into peripheral countries is the main cause of large current account imbalances. Others believe that the loss of external competitiveness is the leading cause of imbalance.

Chinn and Ito (2008) especially emphasized the role of financial development and institutions in the analysis of current account determinants. As an indicator of financial development, the coefficient of private loans/GDP on the sample of 70 developing countries and 19 developed countries was used in the period 1971-2004. They identified the negative impact of this indicator on the current account of both developed and developing countries.

Jaumotte and Sodsriwiboon (2010) applied a panel analysis on the sample of 49 developed countries (including $27 \mathrm{EU}$ members) and emerging markets for the period 1973-2008. These authors found that financial openness reduces the aggregate current account balance, but did not observe a separate impact of financial integration on the core and periphery countries.

Unlike the previous findings, Kentsch (2010) concluded that the current account imbalances within the euro area were mainly due to discrepancies in export performance between the periphery and the core. This is particularly relevant for the period after 2003, when imports were developing with a similar dynamics across the eurozone. The conclusion of this study is that the current account imbalances were created more due to the loss of export competitiveness than the excessive inflow of capital due to financial integration.

Ahearne et al. (2007) and Schmitz and von Hagen (2011) used the data on per capita income as an approximation of financial depth, and in the case of the EU 15, they concluded that the differences in income were followed by net flows, even before the introduction of the euro. Their econometric research has confirmed the existence of differences in the financial depth of the European capital markets, and that capital moved from a country in which it is an abundant factor of production to the countries in which it was a rare factor.

Belke and Dreger (2013) compared the effects of per capita income and competitiveness diferences on the current account, using panel cointegration for 11 eurozone members in different subperiods. By applying this method, these authors concluded that the differences in competitiveness were the main factor of the external imbalance of the euro area. In a separate regression for Greece, Spain and Portugal, the authors pointed to the declining role of per capita income (this variable was used as a substitute for catching up) for these countries over time. In order to reduce the current account deficit of these countries, depreciation of the exchange rate is recommended.

Sanchez and Varoudakis (2013) examined the impact of selected macroeconomic factors on the current account imbalance in the euro area. These authors applied a vector autoregressive model to the panel data for the period 19752011, and did not observe the impact of financial integration. Based on the findings of this model, the authors concluded that demand shocks had more influence on the current account dynamics of the peripheral eurozone members than on the core members, while competitiveness had a lesser role in peripheral members, and a more prominent role in the core countries.

Schmitz and von Hagen (2011) investigated the causes of the current account imbalance 
odnosu na valute glavnih trgovinskih partnera.

Holinski, Kool, and Muysken (2012) su utvrdili da je većina suficita severnih članica evrozone rezultat fiskalne konsolidacije, veće konkurentnosti, stabilnijeg odnosa privatne štednje i investicija i većeg priliva neto faktorskih dohodaka iz inostranstva. Nalazi ovih autora pokazuju da su periferne članice bile suočene sa opadanjem privatne štednje posle 1992, što je dovelo do porasta zaduženosti i pogoršanja trgovinskog bilansa. Periferne članice su bile suočene sa porastom neto odliva faktorskog dohotka do koga je došlo usled porasta spoljne zaduženosti. Međutim, autori smatraju da je širenju deficita tekućeg računa ovih zemalja pre izbijanja krize doprinela prociklična zajednička monetarna politika evrozone.

Alcidi and Gros (2011) su ispitivali razloge zbog kojih su se periferne članice evrozone suočile sa teškoćama prilagođavanja tekućeg računa. Zaključili su da relativno zatvorenije privrede sa niskim stopama štednje pojačavaju fiskalne multiplikatore, zbog čega fiskalna konsolidacija deluje negativno na privredni rast. Niže stope rasta, sa svoje strane, otežavaju prilagođavanje u privatnom sektoru.

Berger and Nitsch (2010) su istraživali bilateralne trgovinske bilanse $\mathrm{u}$ evropskim zemljama u periodu 1948-2008. i utvrdili da su neravnoteže tekućeg računa postale perzistentne posle uvođenja evra. Ovi autori su takođe došli do zaključka da zemlje sa relativno većim fiskalnim deficitom i manje fleksibilnim tržištem rada i proizvoda sistematski pokazuju manje trgovinske suficite nego druge zemlje.

Dominantnu ulogu razvoja finansijskog sektora, deregulacije i posebno masovne pozajmice tokom finansijske krize $u$ evrozoni na tekući račun članica posebno su istakli Pisani-Ferry (2013) and Gibson et al. (2014).

Nasuprot ovom gledištu, Schnabl and Wollmershäuser (2013) tvrde da efekti realnog deviznog kursa nisu posebno robustni, pri čemu glavnu ulogu u generisanju neravnoteža tekućeg računa dodeljuju fiskalnoj politici. Slično gledište u pogledu uloge fiskalne politike nalazimo kod Merler and Pisani-Ferry (2012).

Baxa and Olešňaník (2014) su ocenili da je uvođenje evra uticalo na širenje deficita tekućeg računa perifernih članica evrozone. Ovi autori su takođe utvrdili da se sa uvođenjem evra promenila i uloga fiskalne politike $\mathrm{u}$ dinamici deficita tekućeg računa, i da se u mnogim zemljama javio efekat dvostrukog deficita. Ovo istraživanje je dokumentovalo značajnu ulogu rasta kredita odobrenih privatnom sektoru $\mathrm{u}$ formiranju perzistentnog deficita tekućeg računa.

Comunale i Hessel (2014) su pokazali da su fluktuacije domaće tražnje glavni pokretač dinamike tekućeg računa, dok promene konkurentnosti imaju minornu ulogu. Stoga ovi autori predlažu da se veća pažnja obrati na rast kredita i makro prudencionu politiku, kao dodatak tekućem osvrtu na konkurentnost i strukturne reforme.

Unger (2016) se takođe fokusira na kreditni faktor. Na osnovu empirijskog ispitivanja relacije između kretanja domaćih kredita i bilansa tekućeg računa, ovaj autor je pokazao da bankarski zajmovi odobreni nefinansijskom privatnom sektoru predstavljaju značajnu determinantu tekućeg računa.

\section{Podaci i metodologija istraživanja}

Empirijska analiza dinamike tekućeg računa perifernih članica evrozone $u$ ovom radu zasniva se na godišnjim vremenskim serijama podataka za pet zemalja (zemlje navedene u uvodu). Glavni izvori podataka su Svetska banka, Indikatori svetskog razvoja (World Development Indicators) i MMF, Svetski ekonomski izgledi (World Economic Outlook Database (WEO)). Podaci su normalizovani u odnosu na BDP. Zavisna varijabla u modelu je racio tekućeg računa i BDP-a. Regresori su odabrani prema sugestijama iz literature.

\section{Opis podataka}

Objašnjavajuće varijable $\mathrm{u}$ regresionom modelu su:

Perzistentnost tekućeg računa (eng. current account - $(A)(-1)$. U literaturi postoje brojni dokazi o perzistentnosti CA. Zbog toga ćemo $\mathrm{u}$ analizu kao nezavisnu promenljivu uključiti tekući račun sa pomakom, oznaka (CA)(-1), kao procenat BDP-a (zavisna promenljiva sa docnjom). Zemlje koje u dužem vremenskom intervalu imaju CA deficit teže sprovode njegovo prilagođavanje.

Fiskalni bilans (eng. fiscal balance - FIS). 
within the eurozone and concluded that the per capita income differences between the periphery and the core were the key factor that led to attracting foreign capital and expanding the current account deficit. They also estimated that differences in income increased the impact on the current account imbalance within the eurozone following the introduction of the euro. According to the opinion of these authors, the imbalances with partners outside the EU were influenced by the appreciation of the euro relative to the currencies of the main trading partners.

Holinski, Kool, and Muysken (2012) found that most of the surpluses of the northern eurozone's members are the result of the fiscal consolidation, greater competitiveness, a more stable relationship between private savings and investments, and greater inflows of net factor incomes from abroad. The findings by these authors show that peripheral members were faced with a decline in private savings after 1992, which led to an increase in indebtedness and deterioration in the trade balance. Peripheral members were faced with an increase in the net outflow of factor income due to an increase in external indebtedness. However, the authors believe that the pro-cyclical common monetary policy of the eurozone before the outbreak of the crisis contributed to the widening of the current account deficit of these countries.

Alcidi and Gros (2011) examined the reasons why the peripheral eurozone members faced difficulties in adjusting the current account. They concluded that the relatively closed economies with low savings rates are boosting fiscal multipliers, which makes that fiscal consolidation negatively affect economic growth. Lower growth rates, on their part, make it difficult to adjust in the private sector.

Berger and Nitsch (2010) investigated bilateral trade balances in European countries over the period 1948-2008 and found that the current account imbalances became persistent after the introduction of the euro. These authors also came to the conclusion that countries with a relatively higher fiscal deficit and a less flexible labor and product market systematically show lower trade surpluses than other countries.

The dominant impact of the financial sector development, deregulation and particularly mass borrowings during the eurozone financial crisis on the current accounts of members was specifically highlighted by Pisani-Ferry (2013) and Gibson et al (2014).

In contrast to this view, Schnabl and Wollmershäuser (2013) argue that the effects of the real exchange rate are not particularly robust, the main role in generating the current account imbalance being attributed to fiscal policy. A similar view of the role of fiscal policy is found in Merler and Pisani-Ferry (2012).

Baxa and Olešňaník (2014) estimated that the introduction of the euro affected the expansion of the current account deficit in periphery eurozone members. These authors also found that the role of fiscal policy in the dynamics of the current account deficit was changed with the introduction of the euro, and that the effect of twin deficits occurred in many countries. This survey documented the significant role of credit growth granted to the private sector in the creation of a persistent current account deficit.

Comunale and Hessel (2014) showed that the fluctuations in domestic demand are the main driver of the current account dynamics, while the changes in the competitiveness play a minor role. Therefore, these authors propose that more attention should be paid to credit growth and macro prudential policy, in addition to the ongoing review of competitiveness and structural reforms.

Unger (2016) also focuses on the credit factor. Based on the empirical examination of the relationship between the domestic loans developments and the current account balance, this author showed that bank loans granted to the non-financial private sector are a significant determinant of the current account.

\section{Data and Research Methodology}

The empirical analysis of the current account dynamics of periphery eurozone members in this paper is based on the annual time data series for five countries (countries listed in the introduction). The main sources of data are the World Bank's World Development Indicators, and the IMF's World Economic Outlook Database (WEO). Data are normalized to the GDP. The current account to GDP ratio is the dependent variable in the model. The regressors are selected according to the reference literature suggestions. 
Ova varijabla predstavlja budžetski deficit/ suficit kao \% GDP-a. Fiskalni saldo utiče na agregatnu tražnju, a time i na tražnju za uvoznim proizvodima. Fiskalni deficit pojačava uvoznu tražnju, i time negativno utiče na saldo tekućeg računa. Budžetski deficit, preko viših kamatnih stopa, privlači dodatni strani kapital potreban za njegovo finansiranje, što dovodi do apresijacije domaće valute. Na drugoj strani, porast zaduženosti u tekućem periodu povećava teret servisiranja duga u budućnosti. Ovaj teret može dovesti do porasta stopa oporezivanja u budućnosti. Time više kamatne stope podstiču rast privatne štednje umesto da stimulišu rast investiranja.

Strane direktne investicije (eng. foreign direct investment - FDI). Ova varijabla obuhvata neto priliv stranih direktnih investicija kao procenat GDP-a. Ako se inostrana sredstva koriste za investiranje i podizanje produktivnosti u sektoru razmenljivih dobara, porast neto priliva može pozitivno da deluje na CA. Ako se povećanim prilivom finansira deficit $\mathrm{CA}$, to može dovesti do apresijacije nacionalne valute i smanjivanja izvozne motivisanosti, što negativno utiče na bilans tekućeg računa. Do pogoršanja CA bilansa može doći u slučaju green field investicija, jer one mogu podstaći uvoz. U analizi koristimo seriju FDI sa vremenskom docnjom.

Realni efektivni devizni kurs (eng. real effective exchange rate - REER). Podaci su za REER 2010 $=100$. Ako je indeks deviznog kursa iznad 100 , to znači da je valuta apresirala, što vodi pogoršanju izvozne konkurentnosti zemlje, a time i pogoršanju njenog tekućeg računa. $U$ našoj analizi REER je logaritmovana nezavisna varijabla sa docnjom, kako bi se izbegao problem endogenosti. Ispred regresionog koeficijenta uz ovu varijablu očekuje se negativan znak jer apresijacija destimuliše izvoz a povećava uvoz, što dovodi do pogoršanja CA.

Jaz štednje i investicija (eng. saving investment gap - SIG) dobija se kao razlika štednje i investicija kao \% BDP-a. Ako je štednja veća od investicija, to pozitivno utiče na CA. Ako je štednja manja od investicija, takvo stanje deluje na povećanje deficita $C A$. U našem uzorku perifernih zemalja evrozone, Irska je jedina zemlja kod koje je domaća štednja nadilazila investicije $u$ celom posmatranom periodu, dok je kod ostalih zemalja registrovan promenljiv saldo po godinama. Više stope domaće štednje smanjuju tekuću domaću potrošnju, što pozitivno deluje na CA, a vodi i manjem zaduživanju zemlje u inostranstvu.

Polazni nivo neto strane aktive (eng. net foreign assets - NFA). NFA se posmatra u odnosu na GDP (obe varijable su iskazane $\mathrm{u}$ domaćoj valuti). Veći iznos NFA daje mogućnost zemlji da više uvozi i time formira deficit tekućeg računa. Ako se u praksi to realizuje, veza između NFA i CA je negativna. Ovakav razvoj događaja uglavnom se dešava u polaznom stanju NFA. Vremenom raste dohodak po osnovu polaznih NFA, što ima za posledicu manji uvoz, usled čega NFA deluje pozitivno na tekući račun. U literaturi se smatra da poslednji efekat nadjačava polazni $\mathrm{u}$ otvorenoj privredi, što znači da se u takvom slučaju očekuje pozitivna veza između NFA i CA. U analizi se NFA uzima sa docnjom od jednog perioda, kako bi se izbegao problem endogenosti sa CA.

Razvoj finansijskog sistema. Kao aproksimacija ove pojave koriste se krediti odobreni privatnom sektoru (eng. domestic credit - DC). Za merenje finansijske dubine u ovom radu ćemo koristiti količnik kredita odobrenih privatnom sektoru i GDP (DC kao \% GDP). U literaturi se smatra da razvoj finansijskog sistema podstiče posredništvo, što može dovesti do pogoršanja tekućeg računa (Mendoza et al., 2009). Ispred ove varijable se očekuje negativan predznak.

Veštačka varijabla (eng. dummy - DUMMY). Krizne godine za sve posmatrane zemlje pokrivaju razdoblje od 2009. do 2017. Pošto su sve periferne članice evrozone morale da slede stazu prilagođavanja tekućeg računa, ova veštačka varijabla ima za cilj da pokaže da su zemlje bile zahvaćene finansijskom krizom. U pogledu povezanosti sa $\mathrm{CA}$, ispred ove varijable se očekuje pozitivan znak.

Privatne doznake (eng. private remittances REM). Ova objašnjavajuća varijabla obuhvata primljene doznake kao \% GDP-a. Primljene doznake igraju značajnu ulogu u platnom bilansu perifernih članica evrozone.

Regulatorni kvalitet (eng. regulatory quality REGULAT). Ova varijabla pokazuje sposobnost vlade da formuliše i primeni čvrste politike i regulativu koja treba da unapredi položaj privatnog sektora. U ovom radu se ova varijabla 


\section{Data Description}

The explanatory variables in the regression model are:

Current account persistence (CA)(-1). There are numerous evidence in the reference literature of the CA persistence. Therefore, we will include the current account with the lag, the mark (CA)(-1), as a percentage of GDP (dependent variable with a lag) as an independent variable in the analysis. If countries have a CA deficit for a long time, it will be more difficult for them to implement its adjustment.

Fiscal balance (FIS). This variable represents the budget deficit/surplus as a \% of GDP. The fiscal balance affects the aggregate demand, and therefore the demand for imported products. The fiscal deficit increases the import demand, thereby adversely affecting the current account balance. The budget deficit, through higher interest rates, attracts additional foreign capital needed for its financing, which leads to the appreciation of the domestic currency. On the other hand, the rise in indebtedness in the current period increases the burden of debt servicing in the future. This burden can lead to an increase in taxation rates in the future. This means that the interest rates thereby stimulate the growth of private savings instead of stimulating investment growth.

Foreign direct investment (FDI). This variable includes the net inflow of foreign direct investment as a percentage of GDP. If foreign funds are used for investing and raising productivity in the sector of tradable goods, the increase in net inflows can positively affect the CA. If CA deficit is financed by an increased capital inflow, this can lead to an appreciation of the national currency and a reduction in export motivation, which negatively affects the current account balance. The worsening of the CA balance can occur in the case of green field investments, as they can encourage imports. In the analysis we use the FDI series with a time lag.

The real effective exchange rate (REER). Data are for REER $2010=100$. If the index of foreign exchange rate is above 100, this means that the currency has appreciated, leading to a deterioration in the country's export competitiveness, and thus deterioration in its current account. In our analysis, the REER is an independent variable in the logarithmic form with a lag, for the purpose of avoiding the problem of endogeneity. In front of the regression coefficient with this variable, a negative sign is expected, because the appreciation destimulates exports and increases import, leading to a deterioration in the CA.

Saving investment gap (SIG) is obtained as a difference in savings and investments as a \% of GDP. If savings are greater than investments, this has a positive effect on CA. If savings are lower than investments, such a situation causes an increase in the CA deficit. In our sample of periphery eurozone countries, Ireland is the only country in which domestic savings exceeded investments throughout the observed period, while in other countries a variable balance is recorded. Higher domestic savings rates reduce the current domestic consumption, which positively affects CA, and leads to a country's lower external indebtedness.

Starting level of net foreign assets (NFA). NFA is observed in relation to GDP (both variables are denominated in domestic currency). A larger amount of NFA gives the country the opportunity to import more and thus create a current account deficit. If this is realized in practice, the ratio between NFA and CA is negative. This kind of development occurs mainly in the initial state of the NFA. In time, income grows on the basis of the NFAs, which causes lower imports, resulting in the NFA acting positively on the current account. According to reference literature, the last effect is considered to outweigh the initial one in an open economy, which means that in such a case a positive relationship between NFA and CA is expected. In the analysis, NFA is taken with a lag of one period, in order to avoid the problem of endogeneity with CA.

Development of the financial system. Domestic credit (DC) is used as a proxy for this phenomenon. To measure the financial depth in this paper we will use the ratio of loans granted to the private sector and GDP (DC as a \% GDP). The development of the financial system in reference literature is believed to encourage mediation, which can lead to a deterioration of the current account (Mendoza et al, 2009). A negative sign is expected in front of this variable. 
koristi za proveru robustnosti rezultata. $\mathrm{Ne}$ raspolaže se podacima za 2001. godinu, dok su podaci za ostale godine dostupni. Smatra se da ova varijabla u osnovi pozitivno utiče na tekući račun, jer predstavlja ocenu kvaliteta institucija. Ocene za ovu varijablu se kreću u intervalu od $-2,5$ (slabe performanse) do 2,5 (jake performanse upravljanja). Kvalitetnije institucije povećavaju prinose od investicija, a to vodi pogoršanju tekućeg računa. Zbog toga se ispred ove varijable očekuje pozitivan znak.

Konjunkturni ciklus. Kao aproksimacija konjunkturnog ciklusa, u ovom radu se koristi proizvodni jaz (eng. output gap - GAP). Pozitivan konjunkturni ciklus ima za posledicu veći dohodak, što omogućava veću potrošnju, a time i veći uvoz robe i usluga. Na taj način se ispoljava negativan uticaj na tekući račun. Ovaj pokazatelj je pod uticajem finansijske krize. Ova varijabla u našem radu je izračunata kao aktuelni GDP manje potencijalni GDP kao procenat potencijalnog GDP-a. Očekuje se da ispred ove varijable u regresiji bude negativan znak.

\section{Izvori podataka}

U ovom radu se analizira uzorak perifernih članica evrozone. U regresionoj analizi se koriste panel vremenske serije za pet zemalja. Posmatra se period od 2000 do 2017. godine. Serije poseduju 90 opservacija. U pojedinim serijama za neke godine nedostaju podaci. Podaci su iz sledećih izvora:

- Saldo tekućeg računa (CA) kao \% GDP-a: IMF, World Economic Outlook Database (October 2018). https://www.imf.org/external/ pubs/ft/weo/2018/02/weodata/index.aspx Pristupljeno 14.11.2018.

- Fiskalni bilans (FIS) kao \% GDP-a: IMF, World Economic Outlook Database (October 2018). https://www.imf.org/external/pubs/ft/ weo/2018/02/weodata/index.aspx Pristupljeno 14.11.2018.

- Strane direktne investicije (FDI) kao \% GDP-a: World Bank, World Development Indicators, https://www.imf.org/external/pubs/ft/ weo/2018/02/weodata/index.aspx Pristupljeno 14.11.2018.

- Realni efektivni devizni kurs (REER): World Bank, World Development Indicators (WDI). http://databank.worldbank.org/data/reports. aspx ? source $=$ world-development-indicators. Pristupljeno 14.11.2018.

- Jaz štednje i investicija (SIG) kao \% GDP-a: World Bank, World Development Indicators (WDI). http://databank.worldbank.org/data/ reports.aspx ? source $=$ world-developmentindicators. Pristupljeno 14.11.2018.

- Polazni nivo neto strane aktive (NFA) kao \% GDP-a (izračunato tako što je tekuća vrednost NFA u nacionalnoj valuti podeljena sa tekućim BDP-om u nacionalnoj valuti): World Bank, World Development Indicators (WDI). http://databank.worldbank.org/data/ reports.aspx ? source $=$ world-developmentindicators. Pristupljeno 14.11.2018.

- Razvoj finansijskog sistema (domaći krediti namenjeni privatnom sektoru) (DC) kao \% GDP-a: World Bank, World Development Indicators (WDI). http://databank.worldbank. org $/$ data/reports.aspx ? source $=$ worlddevelopment-indicators. Pristupljeno 14.11.2018.

- Privatne doznake (REM) (primeljene doznake kao \% GDP-a): World Bank, World Development Indicators (WDI). https://www. imf.org/external/pubs/ft/weo/2018/02/weodata/ index.aspx Pristupljeno 14.11.2018.

- Regulatorni kvalitet (REGULAT): World Bank, Worldwide Governance Indicators (WGI). http:// info.worldbank.org/governance/wgi/\#home Pristupljeno 14.11.2018.

- Konjunkturni ciklus (GAP) (izračunato kao aktuelni BDP manje potencijalni GDP kao procenat potencijalnig GDP-a): IMF, World Economic Outlook Database (October 2018). https://www.imf.org/external/pubs/ft/ weo/2018/02/weodata/index.aspx Pristupljeno 14.11.2018.

\section{Metodologija istraživanja}

U ovom radu se testira da li izabrane objašnjavajuće makroekonomske varijable utiču na saldo tekućeg računa perifernih članica EU. U istraživanju je primenjen regresioni panel model. Ocenjeni su koeficijenti sledeće regresione jednačine:

$$
\begin{gathered}
\text { CA }_{\mathrm{it}}=\beta_{\mathrm{i}}+\beta_{1} \cdot \mathrm{CA}_{\mathrm{it}-1}+\beta_{2} \cdot \text { LOGFDI }_{\mathrm{it}-1}+\beta_{3} \cdot \text { FIS }_{\mathrm{it}} \\
+\beta_{4} \cdot \mathrm{GAP}_{\mathrm{it}}+\beta_{5} \cdot \text { LOGREER }_{\mathrm{it}-1}+\beta_{6} \cdot \mathrm{REM}_{\mathrm{it}}+\beta_{7} \\
\cdot \mathrm{NFA}_{\mathrm{it}-1}+\beta_{8} \cdot \mathrm{SIG}_{\mathrm{it}}+\varepsilon_{\mathrm{it}}
\end{gathered}
$$


Dummy (DUMMY). The crisis years for all the countries surveyed cover the period from 2009 to 2017. Since all peripheral eurozone members had to follow the current account adjustment path, this artificial variable aims to show that countries were affected by the financial crisis. In terms of connection with $\mathrm{CA}$, a positive sign is expected in front of this variable.

Private remittances (REM). This explanatory variable includes the received remittances as a $\%$ of GDP. The received remittances play an important role in the balance of payments of the periphery eurozone members.

Regulatory quality (REGULAT). This variable shows the government's ability to formulate and implement sound policies and regulations that should improve the position of the private sector. This variable is in this paper used to check the robustness of the results. The data for 2001 are not available, while the data for other years are available. It is considered that these variables basically influence the current account positively, as they represent an assessment of the quality of institutions. The estimates for this variable range from -2.5 (low performance) to 2.5 (strong management performance). Higher quality institutions increase investment returns, which leads to a worsening of the current account. Therefore, a positive sign is expected in front of this variable.

Business cycle. As an approximation of the business cycle, the output gap (GAP) is used in this paper. A positive business cycle results in higher income, which allows higher consumption, and hence greater imports of goods and services. In this way, there is a negative impact on the current account. This indicator is under the influence of the financial crisis. This variable is in this paper calculated as the current GDP minus the potential GDP as a percentage of the potential GDP. It is expected that in this regression there will be a negative sign in front of this variable.

\section{Data Sources}

The analysis in this paper considers a sample of periphery eurozone members. The regression analysis uses a panel timing series for five countries. The period from 2000 to 2017 is considered. The series has 90 observations.
In some series, the data are missing for some years. The data are from the following sources:

- Current account balance (CA) as \% GDP: IMF, World Economic Outlook Database (October 2018). https://www.imf.org/external/ pubs/ft/weo/2018/02/weodata/index.aspx Accessed 14.11.2018

- Fiscal balance (FIS) as \% GDP: IMF, World Economic Outlook Database (October 2018). https://www.imf.org/external/pubs/ft/ weo/2018/02/weodata/index.aspx Accessed 14.11.2018

- Foreign direct investment (FDI) as \% GDP: World Bank, World Development Indicators, https://www.imf.org/external/pubs/ft/ weo/2018/02/weodata/index.aspx Accessed 14.11.2018

- Real effective exchange rate (REER): World Bank, World Development Indicators (WDI). http://databank.worldbank.org/data/ reports.aspx?source=world-developmentindicators. Accessed 14.11.2018

- Saving Investment Gap (SIG) as \% GDP: World Bank, World Development Indicators (WDI). http://databank.worldbank.org/data/ reports.aspx? source=world-developmentindicators. Accessed 14.11.2018

- Starting level of net foreign assets (NFA) as \% GDP (calculated by dividing the current value of NFA in national currency with current GDP in national currency): World Bank, World Development Indicators (WDI). http://databank.worldbank.org/data/ reports.aspx?source=world-developmentindicators. Accessed 14.11.2018

- Development of the financial system (domestic credit to private sector) (DC) as \% GDP:

- World Bank, World Development Indicators (WDI). http://databank.worldbank.org/data/ reports.aspx? source=world-developmentindicators. Accessed 14.11.2018

- Private remittances (REM) (received remittances as \% GDP): World Bank, World Development Indicators (WDI). https://www. imf.org/external/pubs/ft/weo/2018/02/ weodata/index.aspx Accessed 14.11.2018

- Regulatory quality (REGULAT): World Bank, Worldwide Governance Indicators (WGI). http://info.worldbank.org/governance/ wgi/\#home Accessed 14.11.2018

- Business cycle (GAP) (calculated as the 
gde su koeficijenti definisani u gornjem tekstu. Da bi se proverila robustnost dobijenih rezultata, ocenjena je proširena regresiona jednačina:

$\mathrm{CA}_{\mathrm{it}}=\beta_{\mathrm{i}}+\beta_{1} \cdot \mathrm{CA}_{\mathrm{it}-1}+\beta_{2} \cdot$ LOGFDI $_{\mathrm{it}-1}+\beta_{3} \cdot \mathrm{FIS}_{\mathrm{it}}$ $+\beta_{4} \cdot \operatorname{GAP}_{\mathrm{it}}+\beta_{5} \cdot$ LOGREER $_{\mathrm{it}-1}+\beta_{6} \cdot \mathrm{REM}_{\mathrm{it}}+\beta_{7}$ $\cdot \mathrm{NFA}_{\mathrm{it}-1}+\beta_{8} \cdot \mathrm{SIG}_{\mathrm{it}}+\beta_{9} \cdot \mathrm{DUMMY}_{\mathrm{it}}+\beta_{10} \cdot \mathrm{DC}_{\mathrm{it}}$ + REGULAT $_{\mathrm{it}}+\varepsilon_{\mathrm{it}}\left(\beta_{\mathrm{i}}\right.$ pokriva fiksne efekte zemlje)

Objašnjavajuće varijable su izabrane prema nalazima iz literature. Pre nego što pristupimo ocenjivanju regresione jednačine, testiraćemo panel vremenske serije na postojanje jediničnog korena.

\section{Testovi jediničnog korena u panelu}

U cilju provere stacionarnosti panel vremenskih serija, izvršićemo testiranje koje treba da pokaže da li u serijama postoji jedinični koren. Primenićemo sledeće testove: 1. LevinLin-Chu (2002) test (LLC), 2. Im-Pesaran-Shin (2003) test (IPS), 3. Breitung (2001) test, 4. Fisher-ADF and Fisher-PP test (videti Maddala and Wu, 1999 i Choi, 2001) i 5. Hadri (2000) test. Karakteristično je da LLC, Breitung and Hadri test polaze od pretpostavke da postoji zajednički proces jediničnog korena, a IPS and Fisher-ADF and Fisher-PP test pretpostavljaju da postoji individualni proces jediničnog korena.

\section{Levin-Lin-Chu (LLC) test}

Ovo je jedan od prvih testova jediničnog korena u panelu. Ovaj test su formulisali Levin, Lin and Chu (2002). LLC test se zasniva na oceni sledeće jednačine (osnovna ADF specifikacija) (ova i sledeće jednačine $\mathrm{u}$ ovom odeljku su navedene prema Eviews 8 User Guide II):

$$
\Delta y_{i t}=\alpha y_{i t-1}+\sum_{j=1}^{p_{i}} \beta_{i j} \Delta y_{i t-j}+X_{i t}^{\prime} \delta+\epsilon_{i t}
$$

gde postoji $i=1,2, \ldots, N$ jedinica podataka preseka, posmatranih $\mathrm{u} t=1,2, \ldots, T$, perioda, $X_{i t}^{\prime}$ je egzogena varijabla koja reprezentuje ili konstantu ili konstantu i trend.

U modelu se pretpostavlja da je $\alpha=\varrho-1$, pri čemu su $Q_{i}$ autoregresioni koeficijenti, i da je $\mathrm{Q}_{\mathrm{i}}$ identično za sve jedinice posmatranja. Nulta i alternativna hipoteza $u$ ovom testu mogu se prikazati kao $\mathrm{H}_{10}: \alpha=0$ (postoji jedinični koren kod svake individualne komponente), odnosno $\mathrm{H}_{1 \mathrm{~A}}: \alpha<0$ (ne postoji jedinični koren, odnosno svaka individualna komponenta je stacionarna). LLC metod zahteva specifikaciju broja docnji kod svake jedinice u proširenoj Dickey-Fuller (ADF) regresiji (Dickey and Fuller, 1979), kao i odgovarajući izbor metoda spektralne analize. Takođe se prilikom testiranja moraju specificirati egzogene varijable.

Breitung test se razlikuje od LLC testa jer ne zahteva izbor metoda spektralne analize, već samo specifikaciju broja docnji u svakoj jedinici ADF regresije. Pomoću ovog metoda se izračunava sledeća regresija:

$$
\Delta y_{i t}^{*}=\alpha y_{i t-1}^{*}+\gamma_{i t}(2)
$$

koja ima asimptotski $\mathrm{N}(0,1)$ raspodelu.

Hadri panel test jediničnog korena je sličan KPSS (Kwiatkowsky, et al., 1992) testu jediničnog korena. Nulta hipoteza glasi $\mathrm{H}_{0}: \mathrm{Ni}$ jedna serija u panelu nema jedinični koren. Kao i KPSS test, Hadri test se bazira na rezidualima iz individualnih prostih linearnih regresija (eng. ordinary least squares - OLS) $y_{\text {it }}$ na konstantu, ili na konstantu i trend. Ako se uključe i konstanta i trend, ocenjuje se sledeća relacija:

$$
y_{i t}=\delta_{i}+\mu_{i}^{t}+\epsilon_{i t}(3)
$$

Asimptotska raspodela Hadri testa je normalna, što nije slučaj kod KPSS testa. Hadri test pokazuje velika odstupanja u slučajevima autokorelacije kad ne postoji jedinični koren (posebno u slučajevima kad je T malo). U tim slučajevima Hadri test preterano odbacuje nultu hipotezu o stacionarnosti, i često daje suprotne rezultate $\mathrm{u}$ odnosu na rezultate alternativnih testova (detaljnije o tome diskutuju Hlouskova and Wagner, 2006).

\section{Im, Pesaran, and Shin (IPS) test}

Im, Pesaran, and Shin (2003) test prihvata da postoji individualni proces jediničnog korena. Isto važi i za Fisher-ADF i Fisher-PP test, tako da $\varrho_{i}$ može da varira između jedinica posmatranja. Ovaj test polazi od specifikacije odvojenih ADF regresija za svaku individualnu komponentu. 
current GDP minus the potential GDP as a percentage of the potential GDP): IMF, World Economic Outlook Database (October 2018). https://www.imf.org/external/ pubs/ft/weo/2018/02/weodata/index.aspx Accessed 14.11.2018

\section{Research Methodology}

This paper tests whether the selected explanatory macroeconomic variables affect the current account balance of the periphery member states. The study applied the panel regression model. The coefficients of the following regression equation are estimated:

$$
\begin{gathered}
\text { CA }_{\mathrm{it}}=\beta_{\mathrm{i}}+\beta_{1} \cdot \mathrm{CA}_{\mathrm{it}-1}+\beta_{2} \cdot \text { LOGFDI }_{\mathrm{it}-1}+\beta_{3} \cdot \text { FIS }_{\mathrm{it}} \\
+\beta_{4} \cdot \mathrm{GAP}_{\mathrm{it}}+\beta_{5} \cdot \mathrm{LOGRER}_{\mathrm{it}-1}+\beta_{6} \cdot \mathrm{REM}_{\mathrm{it}}+\beta_{7} \\
\cdot \mathrm{NFA}_{\mathrm{it}-1}+\beta_{8} \cdot \mathrm{SIG}_{\mathrm{it}}+\varepsilon_{\mathrm{it}}
\end{gathered}
$$

where the coefficients are defined in the above text. In order to check the robustness of the obtained results, an extended regression equation is estimated:

$$
\begin{gathered}
\text { CA }_{i t}=\beta_{i}+\beta_{1} \cdot \text { CA }_{i t-1}+\beta_{2} \cdot \text { LOGFDI }_{i t-1}+\beta_{3} \cdot \text { FIS }_{i t} \\
+\beta_{4} \cdot \text { GAP }_{\mathrm{it}}+\beta_{5} \cdot \text { LOGREER }_{\mathrm{it}-1}+\beta_{6} \cdot \mathrm{REM}_{\mathrm{it}}+ \\
\beta_{7} \cdot \mathrm{NFA}_{\mathrm{it}-1}+\beta_{8} \cdot \mathrm{SIG}_{\mathrm{it}}+\beta_{9} \cdot \text { DUMMY }_{\mathrm{it}}+\beta_{10} \cdot \\
\mathrm{DC}_{\mathrm{it}}+\mathrm{REGULAT}_{\mathrm{it}}+\varepsilon_{\mathrm{it}}\left(\beta_{\mathrm{i}}\right. \text { covers the country's } \\
\text { fixed effects }) .
\end{gathered}
$$

Explanatory variables are selected according to the literature findings. Before we approach the estimation of the regression equation, we will test the time series for the existence of a unit root.

\section{Panel Unit Root Tests}

In order to check the stationarity of the panel time series, we will perform tests to show if there is a single root in the series. We will apply the following tests: 1 . Levin-Lin-Chu (2002) test (LLC), 2. Im-Pesaran-Shin (2003) test (IPS), 3. Breitung (2001) test, 4. Fisher-ADF and FisherPP test (see Maddala and Wu, 1999 and Choi, 2001) and 5. Hadri (2000) test. It is charecteristic that LLC, Breitung and Hadri test are based on the assumption that there is a common process of a unit root, and the IPS and Fisher-ADF and Fisher-PP tests assume that there is an individual process of a unit root.

\section{Levin-Lin-Chu (LLC) Test}

This is one of the first panel unit root tests. This test was formulated by Levin, Lin and Chu (2002). The LLC test is based on an estimate of the following equation (the basic ADF specification) (this and the following equations in this section are listed according to EViews 8 User Guide II):

$$
\Delta y_{i t}=\alpha y_{i t-1}+\sum_{j=1}^{p_{i}} \beta_{i j} \Delta y_{i t-j}+X_{i t}^{i} \delta+\epsilon_{i t}
$$

where $i=1,2, \ldots, N$ cross-section units, observed in $t=1,2, \ldots, T$, periods, $X_{i t}^{i}$ is an exogenous variable that represents either a constant or a constant and trend.

The model assumes that $\alpha=\mathrm{Q}-1$, where $\varrho_{\mathrm{i}}$ are autoregressive coefficients, and $\varrho_{i}$ is identical for all observation units. Null and alternative hypotheses in this test can be shown as $\mathrm{H}_{10}$ : $\alpha=0$ (there is a unit root for each individual component), or $\mathrm{H}_{1 \mathrm{~A}}: \alpha<0$ (there is no unit root, or each individual component is stationary). The LLC method requires the specification of the number of lags in each cross-section in the extended Dickey-Fuller (ADF) regression (Dickey and Fuller, 1979), as well as the appropriate kernel choice. Exogenous variables must also be specified during testing.

The Breitung test differs from the LLC test because it does not require the choice of the kernel density, but only the specification of the number lags in each cross-section of the ADF regression. This method calculates the following regression:

$$
\Delta y_{i t}^{*}=\alpha y_{i t-1}^{*}+\gamma_{i t}(2)
$$

which is asymptotically $\mathrm{N}(0,1)$ distributed.

The Hadri panel unit root test is similar to the KPSS (Kwiatkowsky, et al, 1992) unit root test. The null hypothesis is $\mathrm{H}_{0}$ : no unit root in any of the series in the panel. Like the KPSS test, the Hadri test is based on residuals from individual OLS regressions of $\mathrm{y}_{i t}$ on a constant, or a constant and trend. If both the constant and trend are included, the following relationship is estimated:

$$
y_{i t}=\delta_{i}+\mu_{i}^{t}+\epsilon_{i t}(3)
$$


Polazna specifikacija je:

$$
\Delta y_{i t}=\alpha y_{i t-1}+\sum_{j=1}^{p_{i}} \beta_{i j} \Delta y_{i t-j}+X_{i t}^{\prime} \delta+\epsilon_{i t}(4)
$$

Nulta hipoteza je $\mathrm{H}_{20}: \alpha_{\mathrm{i}}=0$, za svako $i$, Dok alternativna hipoteza glasi:

$$
\mathrm{H}_{2 \mathrm{~A}}:\left\{\begin{aligned}
\alpha_{i}=0 \text { za } i & =1,2, \ldots, N_{1} \\
\alpha_{i}<0 \text { za } i & =N+1, N+2, \ldots, N
\end{aligned}\right\}
$$

IPS test $\mathrm{u}$ okviru nulte hipoteze pretpostavlja da su sve serije nestacionarne, odnosno da je deo serija stacionaran $u$ okviru alternativne hipoteze. Po tome se ovaj test razlikuje od LLC testa, gde se pod alternativnom hipotezom pretpostavlja da su sve serije stacionarne. IPS test statistika zahteva specifikaciju broja docnji i specifikaciju determinističke komponente ADF jednačine za svaku jedinicu panela. Može se uključiti individualna konstanta, ili individualna konstanta i trend.

\section{Fisher-ADF i Fisher-PP test}

Alternativni pristup testovima jediničnog korena u panelu formuliše test koji kombinuje p-vrednosti iz pojedinačnih testova jediničnog korena, da bi testirao jedinični koren panela. Ovaj Fisher test su nezavisno formulisali Maddala and Wu (1999) i Choi (2001).

Formula ovog testa je:

$$
-2 \sum_{i=1}^{N} \log \left(\pi_{i}\right) \rightarrow \chi_{2 N}^{2}
$$

Test je asimptotski distribuiran kao $\mathrm{Hi}$ kvadrat sa 2N stepeni slobode.

Choi je pokazao da:

$$
\mathrm{Z}=\frac{1}{\sqrt{N}} \sum_{i=1}^{N} \phi^{-1} \pi_{i} \rightarrow N(0,1)(6)
$$

gde je $\phi^{-1}$ inverzna funkcija standardne normalne kumulativne raspodele. Nulta i alternativna hipoteza su iste kao i za IPS test. Prednost ovog testa je $u$ tome što može da obuhvati nebalansirane panele.

$\mathrm{H}_{2} \mathrm{O}$ implicira da sve vremenske serije $\mathrm{u}$ panelu imaju jedinični koren, i da su nestacionarne, dok alternativna pretpostavlja da je najmanje jedna serija stacionarna. Zbog toga Fišerov test dozvoljava da su neke serije stacionarne a druge nisu.

\section{Testovi kointegracije}

U literaturi se izdvajaju dva tipa kointegracije u panelu - homogena i heterogena. Varijable $\mathrm{u}$ modelu su homogeno kointegrisane ako su vrednosti kointegracionih parametara iste za svaku individualnu jedinicu panela. Heterogena kointegracija podrazumeva da se vrednosti kointegracionih parametara različite za svaku individualnu jedinicu. Među testovima kointegracije $u$ kojima se polazi od pretpostavke nezavisnosti jedinica panela izdvajaju se Kao i Pedroni test, pomoću kojih se testira nulta hipoteza o nestacionarnosti reziduala ocenjene kointegracione jednačine. Daćemo kraći prikaz oba ova testa.

\section{Pedroni test kointegracije}

Pedroni (1999) je predložio nekoliko testova kointegracije $\mathrm{u}$ panelu pod pretpostavkom da su individualne jedinice heterogene (različiti koeficijenti uz konstantu i trend za različite jedinice posmatranja). Polazna kointegraciona regresija u ovom testu može se prikazati kao (Pedroni, 1999, p. 656):

$\mathrm{y}_{i, t}=\alpha_{i}+\delta_{i} t+\beta_{1 i} x_{1, t}+\beta_{2 i} x_{2 i, t}++\beta_{M i} x_{M i, t}+\mathrm{e}_{i, t}(7)$

za $t=1, \ldots, T ; i=1, \ldots, N ; m=1, \ldots, M$; gde je $T$ broj opservacija, $N$ se odnosi na broj individualnih članova panela, a $M$ je broj regresionih varijabli. Model dozvoljava da koeficijenti nagiba $\beta_{1 i^{\prime}} \beta_{2 i^{\prime}}$ ..., $\beta_{\mathrm{Mi}}$ variraju između individualnih jedinica panela. Parameter $\alpha_{\mathrm{i}}$ je parametar fiksnih efekata, koji takođe može da varira između individualnih jedinica. Parameter $\delta_{\mathrm{i}}$ je efekat trenda, koji je specifičan za individualne članove panela. Pretpostavlja se da su $x$ i $y$ integrisani reda 1, odnosno I(1). U okviru nulte hipoteze o odsustvu kointegracije, $e_{i t}$ reziduala će imati I(1). Ocenjivanjem modela (7) dobijaju se reziduali, a zatim se testira da li reziduali poseduju jedan jedinični koren I(1) primenom pomoćne regresije,

$$
\mathrm{e}_{i, t}=\rho_{i} e_{i t-1}+u_{i t}(8)
$$

za svaku jedinicu posmatranja. Pedroni je definisao nekoliko metoda za izračunavanje statistika za testiranje nulte hipoteze $\left(H_{30}: \rho_{i}=1\right)$ za svako $i$. Postoje dve alternativne hipoteze: 
The asymptotic distribution of the Hadri test is normal, which is not the case with the KPSS test. The Hadri test shows great deviations in autocorrelation cases when there is no unit root (especially in cases where $\mathrm{T}$ is low). In these cases, the Hadri test excessively rejects the null hypothesis of stationarity, and often gives opposite results in relation to the results of alternative tests (more details are discussed by Hlouskova and Wagner, 2006).

\section{Im, Pesaran, and Shin (IPS) Test}

The Im, Pesaran, and Shin (2003) test allows for an individual unit root process. The same applies to the Fisher-ADF and Fisher-PP test, so that $Q_{i}$ can vary across cross-sections. This test starts from the specification of separate ADF regressions for each cross section. The starting specification is:

$$
\Delta y_{i t}=\alpha y_{i t-1}+\sum_{j=1}^{p_{i}} \beta_{i j} \Delta y_{i t-j}+X_{i t}^{\prime} \delta+\epsilon_{i t}(4)
$$

Null hypothesis is $\mathrm{H}_{20}: \alpha_{\mathrm{i}}=0$, for each $i$, And the alternative hypothesis is:

$$
\mathrm{H}_{2 \mathrm{~A}}:\left\{\begin{aligned}
& \alpha_{i}=0 \text { za } i=1,2, \ldots, N_{1} \\
& \alpha_{i}<0 \text { za } i=N+1, N+2, \ldots, N
\end{aligned}\right\}
$$

The IPS test in the framework of the null hypothesis assumes that all series are nonstationary, that is, that part of the series is stationary within an alternative hypothesis. Accordingly, this test differs from the LLC test, where under the alternative hypothesis it is assumed that all series are stationary. The IPS test statistics requires a specification of the number of lags and a specification of the deterministic component for each cross section of the ADF equation. An individual constant, or an individual constant and trend can be included.

\section{Fisher-ADF and Fisher-PP Test}

An alternative approach to the panel unit root test formulates a test that combines $p$-values from single root tests to test the panel unit root. This Fisher test was formulated independently by Maddala and Wu (1999) and Choi (2001).

The formula for this test is:

$$
-2 \sum_{i=1}^{N} \log \left(\pi_{i}\right) \rightarrow \chi_{2 N}^{2}(5)
$$

The test is asymptotically distributed as chisquared with $2 \mathrm{~N}$ degrees of freedom.

Choi showed that:

$$
\mathrm{Z}=\frac{1}{\sqrt{N}} \sum_{i=1}^{N} \phi^{-1} \pi_{i} \rightarrow N(0,1)(6)
$$

where $\phi^{-1}$ is an inverse function of the standard normal cumulative distribution. The null and alternative hypotheses are the same as for the IPS test. The advantage of this test is that it can include unbalanced panels.

$\mathrm{H}_{2} \mathrm{O}$ implies that all panel time series have a unit root, and that they are non-stationary, while the alternative assumes that at least one series is stationary. That is why Fischer's test allows some series to be stationary while others are not.

\section{Cointegration Tests}

The two types of the panel cointegration are distinguished in the literature - homogeneous and heterogeneous. The variables in the model are homogeneously cointegrated if the values of the cointegration parameters are the same for each individual panel unit. Heterogeneous cointegration implies that the values of cointegration parameters are different for each individual unit. Among the cointegration tests with the assumption of independence of the panel units Kao and Pedroni test stand out, which are used to test the null hypothesis of the unstationarity of the residual of the estimated cointegration equation. We will provide a brief overview of both these tests.

\section{Pedroni Cointegration Tests}

Pedroni (1999) proposed several cointegration tests in the panel assuming that individual units are heterogeneous (different coefficients with a constant and trend for different observation units). The initial cointegration regression in this test can be shown as (Pedroni, 1999, p. 656):

$\mathrm{y}_{i, t}=\alpha_{i}+\delta_{i} t+\beta_{1 i} x_{1 i, t}+\beta_{2 i} x_{2 i, t}++\beta_{M i} x_{M i, t}+\mathrm{e}_{i, t}(7)$

for $t=1, \ldots, T ; i=1, \ldots, N ; m=1, \ldots, M$; where $\mathrm{T}$ is the number of observations, $\mathrm{N}$ refers to the number of individual panel members, and 
Homogena alternativa $\left(H_{3 A 1}: \rho_{i}=\rho<1\right)$ za svako $i$ (test unutar dimenzije), i heterogena alternativa $\left(H_{3 A 2}: \rho_{i}<1\right)$ za sve $i$ (test između dimenzije). Pedroni je pokazao da standardizovane test-statistike imaju asimptotski normalnu raspodelu sa parametrima $0 \mathrm{i} 1$. U programu EViews koji smo koristili u ovom radu postoji jedanaest statistika Pedroni testa.

\section{Kao test kointegracije}

Kao (1999) test sledi osnovni pristup kao i Pedroni test, ali uz pretpostavku da su individualne jedinice homogene. $U$ dvosmernom slučaju, Kao test se prikazuje kao (Eviews 8 Users Guide II, pp. 865-866),

$$
y_{i t}=\alpha+\beta x_{i t}+e_{i t}(9)
$$

za

$$
\begin{aligned}
& y_{i t}=y_{i t-1}+u_{i t}(10) \\
& x_{i t}=x_{i t-1}+\varepsilon_{i t}(11)
\end{aligned}
$$

za $t=1, \ldots, T ; i=1, \ldots, N$.

Kao je definisao pet varijanti Dickey-Fuller testa reziduala (DFR). Svih pet test-statistika $\mathrm{u}$ asimptotskim uslovima poseduje normalnu raspodelu sa parametrima 0 i 1.

Za ocenu kointegracione jednačine u panelu koristićemo FMOLS (Fully Modified OLS) i DOLS (Dynamic OLS) estimatore (videti Phillips and Hansen, 1990).

\section{Empirijski rezultati i diskusija}

U tabeli A u prilogu se daju ocene primenjenih testova jediničnog korena $\mathrm{u}$ panelu za izabrane makroekonomske varijable koje utiču na neravnotežu tekućeg računa u uzorku od pet perifernih članica evrozone. U cilju provere stepena integrisanosti izabranih varijabli, u radu je primenjeno nekoliko testova jediničnog korena prve generacije (LLC, IPS, ADF-Fisher Hi kvadrat, PP-Fisher Hi kvadrat, Hadri test). Veći broj testova je primenjen da bi se izbegle njihove slabosti koje se ispoljavaju u slučajevima kraćih vremenskih serija. Sve varijable se odnose na period 20002017. godine. U jednačinu za testiranje kod svih testova uključeni su individualni efekti ili opcija koja obuhvata individualne efekte zajedno sa individualnim trendom. Testovi su primenjeni na nivo pojave i prvu diferencu svih varijabli. Dobijeni rezultati se daju u tabeli A u prilogu. U ovom istraživanju nije proveravana stacionarnost varijabli kvalitativne prirode $\mathrm{i}$ veštačkih varijabli koje su korišćene u modelu.

Podaci u tabeli A u prilogu pokazuju da je kod većine testova jediničnog korena otkriveno prisustvo jediničnog korena u nivou serije, na nivou značajnosti od $5 \%$. Dodatna provera na nivou prve diference je pokazala da su sve serije stacionarne, odnosno da su integrisane reda 1 $((X t \sim I(1))$. Izuzetak je promenljiva koja predstavlja realni efektivni devizni kurs (REER) čiju stacionarnost prve diference nije potvrdio Hadri test, kao i varijable krediti odobreni privatnom sektoru (DC) i proizvodni jaz (GAP), gde nekoliko testova nije potvrdilo stacionarnost prve diference. $\mathrm{S}$ obzirom da su ispunjeni preduslovi, primenili smo Pedroni i Kao test za proveru postojanja kointegracije između varijable tekući račun (CA) i ostalih makroekonomskih varijabli. Kod oba testa se proverava nulta hipoteza koja tvrdi da su reziduali ocenjene kointegracione jednačine nestacionarni, odnosno da reziduali dobijeni iz regresione jednačine poseduju jedinični koren. Ako su varijable kointegrisane, onda su reziduali stacionarni $\mathrm{I}(0)$.

Pedroni kointegracioni test ima dve varijante. Prva varijanta ovog testa polazi od pretpostavke da postoji homogena kointegracija $u$ panelu (jedinstvena ravnotežna veza za sve zemlje), dok se druga varijanta zasniva na pretpostavci da $\mathrm{u}$ panelu postoji heterogena kointegracija (različite ravnotežne veze po zemljama). Svaka varijanta testa ima dve mogućnosti u pogledu uključivanja determinističkih komponenti u kointegracionu jednačinu: prva opcija podrazumeva da je uključena samo individualna komponenta, dok druga sadrži individualne efekte i trend. $U$ tabeli 1 su prikazani rezultati 11 Pedronijevih statistika, svrstanih u dve grupe. U prvoj grupi se nalaze i tri testa koji u okviru alternativne hipoteze pretpostavljaju heterogenu kointegraciju $\mathrm{u}$ panelu. Ostali testovi pretpostavljaju homogenu kointegraciju u panelu. Na osnovu 6 od 11 testova u opciji gde su zastupljeni individualni fiksni efekti i trend, odbacuje se nulta hipoteza o odsustvu kointegracije na nivou značajnosti od $1 \%$. Sledi zaključak da, prema ovom testu, postoji dugoročna usklađenost u kretanju posmatranih vremenskih serija panela za skup perifernih članica evrozone. 
$\mathrm{M}$ is the number of regression variables. The model allows the slope coefficients $\beta_{1 i^{\prime}} \beta_{2 i^{\prime}}$..., $\beta_{\mathrm{Mi}}$ to vary across individual members of the panel. The $\alpha_{\mathrm{i}}$ is a fixed effect parameter, which can also vary between individual units. The parameter $\delta_{i}$ is a trend effect, which is specific to individual panel members. It is assumed that $x$ and $y$ are an integrated order of $1, \mathrm{I}(1)$. In the framework of the null hypothesis about the absence of cointegration, the $e_{i t}$ residual will have I(1). By estimating the model (7) residuals are obtained, and then it is tested whether the residuals possess one unit root I (1) by applying auxiliary regression,

$$
\mathrm{e}_{i, t}=\rho_{i} e_{i t-1}+u_{i t}(8)
$$

for each cross-section. Pedroni has defined several methods for calculating statistics for testing the null hypothesis $\left(H_{30}: \rho_{i}=1\right)$ for all $i$. There are two alternative hypotheses: a homogeneous alternative $\left(H_{3 A 1}: \rho_{i}=\rho<1\right)$ for all $i$ (the within-dimension test), and heterogeneous alternative $\left(H_{3 A 2}: \rho_{i}<1\right)$ za all $i$ (betweendimension test). Pedroni has shown that the standardized test statistics have the asymptotic normal distribution with parameters 0 and 1 . In the EViews program we used in this work, there are eleven Pedroni test statistics.

\section{Kao Cointegration Tests}

Kao (1999) test follows the basic approach like the Pedroni test, but assuming that the individual units are homogeneous. In the bivariate case, the test is shown as (EViews 8 Users Guide II, pp. 865-866),

$$
y_{i t}=\alpha_{i}+\beta x_{i t}+e_{i t}(9)
$$

for

$$
\begin{aligned}
& y_{i t}=y_{i t-1}+u_{i t}(10) \\
& x_{i t}=x_{i t-1}+\varepsilon_{i t}(11)
\end{aligned}
$$

for $t=1, \ldots, T ; i=1, \ldots, N$.

Kao defined five variants of the DickeyFuller residual test (DFR). All five test-statistics in asymptotic conditions have a normal distribution with parameters 0 and 1 .

To estimate the panel cointegration equation we will use FMOLS (Fully Modified OLS) and
DOLS (Dynamic OLS) estimators (see Phillips and Hansen, 1990).

\section{Empirical Results and Discussion}

Table A in the Appendix provides estimates of the applied unit root tests in the panel for selected macroeconomic variables that affect the current account imbalance in a sample of five peripheral eurozone members. In order to check the degree of integration of the selected variables, several unit root tests (LLC, IPS, ADFFisher Hi squared, PP-Fisher Hi squared, Hadri test) were used. A large number of tests have been applied to avoid their weaknesses that are manifested in cases of shorter time series. All variables refer to the period 2000-2017. The test equation for all tests includes individual effects or an option that includes individual effects along with an individual trend. Tests were applied to the level of occurrence and the first difference of all variables. The obtained results are given in Table $\mathrm{A}$ in the annex. The stationarity for the qualitative variables and artificial variables used in the model were not checked in this study.

The data in Table A in the Appendix show presence of a unit root for most unit root tests at the level of the series, with significance of $5 \%$. An additional check at the first differential level showed that all series are stationary, that is, the integrated order $1((\mathrm{Xt} \sim \mathrm{I}(1))$. The exception is the variable that represents the real effective exchange rate (REER) whose stationarity of the first differential has not been confirmed by the Hadri test, as well as variable credits granted to the private sector (DC) and the output gap (GAP), where several tests did not confirm the first diference stability. Since the preconditions were met, we applied the Pedroni and Kao test to check the existence of cointegration between the current account (CA) variable and other macroeconomic variables. The null hypothesis according to which the residuals of the estimated cointegration equation are non-stationary, or the residuals obtained from the regression equation possess a unit root, is examined in both tests.

The Pedroni cointegration test has two variants. The first variant of this test is based on the assumption that there is a homogeneous 
Tabela 1. Pedronijev test kointegracije u panelu perifernih članica evrozone

\begin{tabular}{|c|c|c|c|c|}
\hline Test & \multicolumn{4}{|c|}{ Individualni fiksni efekti } \\
\hline \multirow{4}{*}{$\begin{array}{l}\text { Homogena kointegracija } \\
\text { Alternativna hipoteza: zajednički } \\
\text { autoregresioni koeficijent }\end{array}$} & Panel v-Stat. & Panel rho-Stat. & Panel PP-Stat. & Panel ADF-Stat. \\
\hline & $\begin{array}{l}-1,31 \\
(0,90)\end{array}$ & $\begin{array}{c}0,89 \\
(0,81)\end{array}$ & $\begin{array}{l}-9,11 \\
(0,00)\end{array}$ & $\begin{array}{l}-1,47 \\
(0,07)\end{array}$ \\
\hline & \multicolumn{4}{|c|}{ Ponderisana statistika } \\
\hline & $\begin{array}{l}-1,49 \\
(0,93)\end{array}$ & $\begin{array}{c}2.04 \\
(0,98)\end{array}$ & $\begin{array}{l}-5,03 \\
(0,00)\end{array}$ & $\begin{array}{l}-3,36 \\
(0,00)\end{array}$ \\
\hline \multirow{3}{*}{$\begin{array}{l}\text { Heterogena kointegracija } \\
\text { Alternativna hipoteza: } \\
\text { individualni autoregresioni } \\
\text { koeficijent } \\
\end{array}$} & Group rho & Group PP & Group ADF & \\
\hline & $\begin{array}{c}3,48 \\
(0,99)\end{array}$ & $\begin{array}{l}-9,99 \\
(0,00)\end{array}$ & $\begin{array}{l}-6,17 \\
(0,00)\end{array}$ & \\
\hline & \multicolumn{4}{|c|}{ Individualni fiksni efekti i trend } \\
\hline \multirow{4}{*}{$\begin{array}{l}\text { Homogena kointegracija } \\
\text { Alternativna hipoteza: zajednički } \\
\text { autoregresioni koeficijent }\end{array}$} & Panel v-Stat. & Panel rho-Stat. & Panel PP-Stat. & Panel ADF-Stat. \\
\hline & $\begin{array}{l}-2,08 \\
(0,98)\end{array}$ & $\begin{array}{c}1,60 \\
(0,95)\end{array}$ & $\begin{array}{r}-17,29 \\
(0,00)\end{array}$ & $\begin{array}{l}-5,22 \\
(0,00)\end{array}$ \\
\hline & \multicolumn{4}{|c|}{ Ponderisana statistika } \\
\hline & $\begin{array}{l}-2,19 \\
(0,99)\end{array}$ & $\begin{array}{c}2.85 \\
(0,99)\end{array}$ & $\begin{array}{l}-8,51 \\
(0,00)\end{array}$ & $\begin{array}{l}-4,31 \\
(0,00)\end{array}$ \\
\hline \multirow{3}{*}{$\begin{array}{l}\text { Heterogena kointegracija } \\
\text { Alternativna hipoteza: } \\
\text { individualni autoregresioni } \\
\text { koeficijent }\end{array}$} & Group rho & Group PP & Group ADF & \\
\hline & $\begin{array}{c}3,48 \\
(0,99)\end{array}$ & $\begin{array}{l}-9,99 \\
(0,00)\end{array}$ & $\begin{array}{l}-6,17 \\
(0,00)\end{array}$ & \\
\hline & \multicolumn{4}{|c|}{ Individualni efekti } \\
\hline \multirow[t]{2}{*}{ Kaoov test kointegracije } & ADF statistic & & & \\
\hline & $\begin{array}{l}-0,56 \\
(0,29)\end{array}$ & & & \\
\hline
\end{tabular}

Napomene: Podaci u zagradi ispod t vrednosti statistike testa $(t)$ su p-vrednosti. Nulta hipoteza Pedroni i Kao testa glasi: nema kointegracije. U kointegracionu jednačinu su uključeni individualni fiksni efekti i trend kao determinističke komponente. Docnja je automatski određena pomoću Schwarz informacionog kriterijuma (eng. Schwarz information criterion - SIC) sa maksimalno dve docnje.

Izvor: Proračun autora.

Za proveru robustnosti zaključaka izvedenih na osnovu Perdoni testa, koristili smo Kao i Fisher test. Kao test statistika nije pružila mogućnost da se odbaci nulta hipoteza o odsustvu kointegracije. Pošto vrednosti test statistike zavise od veličine uzorka, naš panel sa godišnjim podacima ima kraću vremensku dimenziju, što smanjuje pouzdanost zaključivanja o stacionarnosti serije. Sem toga, kriza iz 2008. godine je izazvala poremećaje u trendovima posmatranih varijabli. Za razliku od Kao testa, rezultati Johansen-Fisher (Johansen, 1991) testa kointegracije podržavaju postojanje kointegracione veze između posmatranih varijabli, kako prema test statistici traga, tako i prema testu maksimalne verodostojnosti. Ako se varira broj endogenih promenljivih kao i broj docnji prve diference ovih varijabli, varira i broj kointegracionih vektora od 1 do 2 , koje ovaj test preporučuje na osnovu statistike traga.

Pošto je na osnovu većine testova ustanovljeno postojanje kointegracije, potrebno je da ocenimo koeficijente kointegracione jednačine, odnosno da ocenimo dugoročnu vezu između analiziranih makroekonomskih varijabli pomoću FMOLS and DOLS modela. Ocenjeni koeficijenti daju se u tabeli 2. 
cointegration in the panel (a unique equilibrium for all countries), while the second variant is based on the assumption that there is heterogeneous cointegration in the panel (different equilibrium across countries). Each variant of the test has two options regarding the inclusion of deterministic components in the cointegration equation: the first option implies that only an individual component is involved, while the other one includes individual effects and a trend. Table 1 shows the results of 11 Pedronian statistics, divided into two groups. The first group includes three tests, which assume heterogeneous cointegration in the panel within the alternative hypothesis. Other tests assume homogeneous cointegration in the panel. Based on 6 out of 11 tests in the option involving individual fixed effects and trends, the null hypothesis of no cointegration is rejected at a significance level of $1 \%$. The conclusion is that, according to this test, there is a long-term compliance in the developments of the observed panel time series for a set of peripheral eurozone members.

To check the robustness of the conclusions derived from the Perdoni test, we used Kao and Fisher tests. The Kao test did not provide an opportunity to reject the null hypothesis of no cointegration. Since the test statistic values depend on the size of the sample, our annual panel data have a shorter time dimension, which reduces the reliability of conclusions about the time series stationarity. In addition, the 2008 crisis caused disruptions in the trends of the observed variables. In contrast to the Kao test, Johansen-Fisher (Johansen, 1991) results of the cointegration test support the existence of a co-integration relationship between the observed variables, both according to the trace test, and the maximum eigenvalue test. If the number of endogenous variables varies as well as the number lags of the first differential of these variables, the number of cointegration vectors also varies from 1 to 2 , which this test recommends based on the trace statistics.

Since the existence of cointegration has been established by the most tests, it is necessary to estimate the coefficients of the cointegration equation, or to estimate the long-term relationship between the analyzed

Tabele 1. Pedroni cointegration test for a panel of periphery eurozone countries

\begin{tabular}{|c|c|c|c|c|}
\hline Test & \multicolumn{4}{|c|}{ Individual fixed effects } \\
\hline \multirow{4}{*}{$\begin{array}{l}\text { Homogeneous cointegration } \\
\text { Alternative hypothesis: common } \\
\text { autoregressive coefficient }\end{array}$} & Panel v-Stat. & Panel rho-Stat. & Panel PP-Stat. & Panel ADF-Stat. \\
\hline & $\begin{array}{l}-1.31 \\
(0.90)\end{array}$ & $\begin{array}{c}0.89 \\
(0.81)\end{array}$ & $\begin{array}{l}-9.11 \\
(0.00)\end{array}$ & $\begin{array}{l}-1.47 \\
(0.07)\end{array}$ \\
\hline & \multicolumn{4}{|c|}{ Weighted statistics } \\
\hline & $\begin{array}{l}-1.49 \\
(0.93)\end{array}$ & $\begin{array}{c}2.04 \\
(0.98)\end{array}$ & $\begin{array}{l}-5.03 \\
(0.00)\end{array}$ & $\begin{array}{l}-3.36 \\
(0.00)\end{array}$ \\
\hline \multirow{3}{*}{$\begin{array}{l}\text { Heterogeneous cointegration } \\
\text { Alternative hypothesis: individual } \\
\text { autoregression coefficient }\end{array}$} & Group rho & Group PP & Group ADF & \\
\hline & $\begin{array}{c}3.48 \\
(0.99)\end{array}$ & $\begin{array}{l}-9.99 \\
(0.00)\end{array}$ & $\begin{array}{l}-6.17 \\
(0.00)\end{array}$ & \\
\hline & \multicolumn{4}{|c|}{ Individual fixed effects and trend } \\
\hline \multirow{4}{*}{$\begin{array}{l}\text { Homogeneous cointegration } \\
\text { Alternative hypothesis: common } \\
\text { autoregressive coefficient }\end{array}$} & Panel v-Stat. & Panel rho-Stat. & Panel PP-Stat. & Panel ADF-Stat. \\
\hline & $\begin{array}{l}-2.08 \\
(0.98)\end{array}$ & $\begin{array}{c}1.60 \\
(0.95)\end{array}$ & $\begin{array}{l}-17.29 \\
(0.00)\end{array}$ & $\begin{array}{l}-5.22 \\
(0.00)\end{array}$ \\
\hline & \multicolumn{4}{|c|}{ Weighted statistics } \\
\hline & $\begin{array}{l}-2.19 \\
(0.99)\end{array}$ & $\begin{array}{c}2.85 \\
(0.99) \\
\end{array}$ & $\begin{array}{l}-8.51 \\
(0.00)\end{array}$ & $\begin{array}{l}-4.31 \\
(0.00)\end{array}$ \\
\hline \multirow{3}{*}{$\begin{array}{l}\text { Heterogeneous cointegration } \\
\text { Alternative hypothesis: individual } \\
\text { autoregression coefficient }\end{array}$} & Group rho & Group PP & Group ADF & \\
\hline & $\begin{array}{c}3.48 \\
(0.99) \\
\end{array}$ & $\begin{array}{l}-9.99 \\
(0.00)\end{array}$ & $\begin{array}{l}-6.17 \\
(0.00)\end{array}$ & \\
\hline & \multicolumn{4}{|c|}{ Individual effects } \\
\hline \multirow[t]{2}{*}{ Kao cointegration test } & ADF statistic & & & \\
\hline & $\begin{array}{l}-0.56 \\
(0.29)\end{array}$ & & & \\
\hline
\end{tabular}

Notes: Data in brackets below the $t$ values of test statistics $(t)$ are p-values. The Null hypothesis of the Pedroni and Kao test is: no cointegration. The cointegration equation includes individual fixed effects and trend as deterministic components. The lag length is determined automatically by the Schwarz information criterion (SIC) with a maximum lag of two.

Source: Author's calculations. 
Tabela 2. Determinante tekućeg računa perifernih članica evrozone - rezultati FMOLS and DOLS modela, ceo period 20002017. i potperiod 2008-2017. godine

\begin{tabular}{|l|c|c|c|c|}
\hline & \multicolumn{2}{|c|}{$2000-2017$} & \multicolumn{2}{c|}{$2008-2017$} \\
\cline { 2 - 5 } & FMOLS & DOLS & FMOLS & DOLS \\
\hline \multirow{2}{*}{ Tekući račun - CA(-1) } & 0,27 & 0,26 & 0,09 & 0,13 \\
& $(0,00)$ & $(0,00)$ & $(0,02)$ & $(0,03)$ \\
\hline Strane direktne investicije - & $-8,86$ & $-8,41$ & 0,30 & 2,42 \\
LOGFDI(-1) & $(0,00)$ & $(0,04)$ & $(0,91)$ & $(0,65)$ \\
\hline \multirow{2}{*}{ Fiskalni bilans - FIS } & $-0,07$ & $-0,03$ & 0,07 & 0,06 \\
& $(0,02)$ & $(0,53)$ & $(0,05)$ & $(0,24)$ \\
\hline \multirow{2}{*}{ Proizvodni jaz - GAP } & $-0,10$ & $-0,15$ & $-0,09$ & $-0,05$ \\
& $(0,00)$ & $(0,02)$ & $(0,02)$ & $(0,49)$ \\
\hline Realni efektivni devizni kurs - & $-9,92$ & $-9,02$ & $-0,07$ & 1,50 \\
LOGREER(-1) & $(0,00)$ & $(0,00)$ & $(0,99)$ & $(0,84)$ \\
\hline \multirow{2}{*}{ Doznake - REM } & $-0,54$ & 0,44 & 1,01 & 0,93 \\
& $(0,32)$ & $(0,65)$ & $(0,10)$ & $(0,43)$ \\
\hline \multirow{2}{*}{ Neto inostrana aktiva - NFA(-1) } & $-0,01$ & 0,00 & $-0,00$ & $-0,01$ \\
& $(0,06)$ & $(0,99)$ & $(0,63)$ & $(0,71)$ \\
\hline \multirow{2}{*}{ Jaz štednje i investicija - SIG } & 0,73 & 0,72 & 1,04 & 1,07 \\
& $(0,00)$ & $(0,00)$ & $(0,00)$ & $(0,00)$ \\
\hline
\end{tabular}

Napomene: Model za ocenu kointegracione jednačine: Panel FMOLS (eng. Fully Modified Ordinary Least Squares); Panel metod: model sa konstantnim parametrima - (pooled model); Kointegraciona konstanta $(\mathrm{C})$; Prvi nivo reziduala uz primenu heterogenih dugoročnih koeficijenta; Ocena dugoročne kovarijacione matrice dobijena je pomoću Newey-West ocene Bartlett spektra; U zagradama su date p-vrednosti. Metod za ocenu kointegracione jednačine: Panel DOLS (eng. Dynamic Ordinary Least Squares): Kointegraciona konstanta (C); Ocena dugoročne kovarijacione matrice dobijena je pomoću Newey-West ocene Bartlett spektra; U zagradama su date p-vrednosti. Panel metod: model sa konstantnim parametrima - (pooled model). Većina regresora nije u logaritamskom izrazu zbog postojanja negativnih vrednosti u panel vremenskim serijama, usled čega serije nisu mogle da se transformišu u logaritamske. Izvor: Proračuni autora.

Specifikacija kointegracione jednačine je sa fiksnim efektima. U panel vremenskim serijama korišćeni su godišnji podaci. Kointegracioni model je ocenjen za ceo uzorački period (20002017), kao i za potperiod (2008-2017). Ocenjen je FMOLS model sa konstantnim parametrima, pri čemu se koristi samo konstanta kao specifični trend regresor u podacima preseka. Prilikom ocene kointegracione jednačine pomoću dinamičnog modela najmanjih kvadrata (DOLS) koristi se konstanta kao deterministička komponenta. Rezultati u tabeli 2 pokazuju da posmatrane determinante dugoročno utiču na tekući račun perifernih članica evrozone (varijabla GAP reprezentuje uticaj konjunkture). Ocenjeni koeficijenti pomoću FMOLS estimatora u celom vremenskom periodu 20002017. su statistički značajni na nivou od $1 \%$ za sve regresore, izuzev koeficijenta uz doznake (ukoliko se kao objašnjavajuća varijabla koriste logaritmovane vrednosti stranih direktnih investicija bez docnje, onda ocenjeni koeficijent uz doznake postaje statistički značajan na nivou od $10 \%$ ). Znaci ispred ocenjenih regresionih koeficijenata su u skladu sa teorijskim očekivanjima. Varijabla realnog efektionog deviznog kursa (logaritmovane vrednosti) uključena je u regresionu jednačinu sa vremenskom docnjom i pokazuje negativan uticaj na tekuće račun zbog apresijacije realnog kursa. Negativan znak uz promenljivu fiskalni bilans pokazuje da je fiskalni deficit u razdoblju do 2008. godine doprinosio pogoršanju bilansa tekućeg računa posmatranih zemalja. Pozitivan znak uz promenljivu neto strana aktiva sa vremenskim pomakom potvrđuje teorijski stav po kome se $\mathrm{u}$ otvorenim privredama vremenom povećava dohodak od inostranih sredstava, što smanjuje uvoz. Ocenjena vrednost koeficijenta uz proizvodni jaz ima negativan predznak, što pokazuje da rast privredne aktivnosti $u$ perifernim članicama evrozone podrazumeva rast uvoza, a to deluje negativno na saldo tekućeg računa. Pozitivan predznak uz promenljivu jaz štednja-investicije govori u prilog tezi da rast štednje pozitivno utiče na saldo tekućeg računa u posmatranom skupu zemalja. Rastu štednje doprinose doznake, a pozitivan znak uz ovu promenljivu potvrđuje njihov doprinos. Ocenjeni koeficijent uz varijablu tekući račun sa docnjom od jednog perioda $(C A(-1))$ potvrđuje perzistentnost deficita tekućeg računa perifernih članica evrozone. Slične ocene se mogu doneti na osnovu kvantitativnih vrednosti koeficijenata iz ocenjene kointegracione jednačine pomoću DOLS estimatora. Međutim, koeficijent uz fiskalni saldo nije statistički signifikantan, dok je većina ostalih koeficijenata signifikantna na nivou od $1 \%$ (koeficijenti uz neto stranu aktivu sa docnjom od jednog perioda i logaritmovanu vrednost stranih direktnih investicija, takođe sa docnjom od jednog perioda, su statistički značajni na nivou od $5 \%$ ). U razdoblju posle izbijanja svetske finansijske krize (2008-2017) svi 
macroeconomic variables using the FMOLS and DOLS models. The estimated coefficients are given in Table 2.

The specification of the cointegration coefficient (if the logarithmic values of foreign direct investment are used as explanatory variable without lag, the estimated remittances coefficient becomes statistically significant at
Tabele 2. The current account determinants of periphery eurozone members - results of the FMOLS and DOLS model, the entire period 2000-2017 and subperiod 2008-2017

\begin{tabular}{|l|c|c|c|c|}
\hline & \multicolumn{2}{|c|}{$2000-2017$} & \multicolumn{2}{c|}{$2008-2017$} \\
\cline { 2 - 5 } & FMOLS & DOLS & FMOLS & DOLS \\
\hline \multirow{2}{*}{ Current Account - CA(-1) } & 0.27 & 0.26 & 0.09 & 0.13 \\
& $(0.00)$ & $(0.00)$ & $(0.02)$ & $(0.03)$ \\
\hline Foreign Direct Investment - & -8.86 & -8.41 & 0.30 & 2.42 \\
LOGFDI(-1) & $(0.00)$ & $(0.04)$ & $(0.91)$ & $(0.65)$ \\
\hline \multirow{2}{*}{ Fiscal balance - FIS } & -0.07 & -0.03 & 0.07 & 0.06 \\
& $(0.02)$ & $(0.53)$ & $(0.05)$ & $(0.24)$ \\
\hline \multirow{2}{*}{ Output gap - GAP } & -0.10 & -0.15 & -0.09 & -0.05 \\
& $(0.00)$ & $(0.02)$ & $(0.02)$ & $(0.49)$ \\
\hline Real Effective Exchange Rate - & -9.92 & -9.02 & -0.07 & 1.50 \\
LOGREER(-1) & $(0.00)$ & $(0.00)$ & $(0.99)$ & $(0.84)$ \\
\hline \multirow{2}{*}{ Remittances - REM } & -0.54 & 0.44 & 1.01 & 0.93 \\
& $(0.32)$ & $(0.65)$ & $(0.10)$ & $(0.43)$ \\
\hline \multirow{2}{*}{ Net foreign assets - NFA(-1) } & -0.01 & 0.00 & -0.00 & -0.01 \\
& $(0.06)$ & $(0.99)$ & $(0.63)$ & $(0.71)$ \\
\hline \multirow{2}{*}{ Saving-Investment Gap - SIG } & 0.73 & 0.72 & 1.04 & 1.07 \\
& $(0.00)$ & $(0.00)$ & $(0.00)$ & $(0.00)$ \\
\hline
\end{tabular}

Notes: Model for estimating the cointegration equation: Panel FMOLS (Fully Modified Ordinary Least Squares); Panel method: model with constant parameters - (pooled model); Cointegration constant (C); First level of residuals using heterogeneous long-term coefficients; The estimation of the long-run covariance matrix was obtained using the Newey-West estimation of the Bartlett kernel; p-values are given in brackets. Method for estimating the cointegration equation: Dynamic Ordinary Least Squares (DOLS): Cointegration Constant (C); The estimation of the long-run covariance matrix was obtained using the Newey-West estimation of the Bartlett kernel; p-values are given in brackets. Panel method: a model with constant parameters - (pooled model). Most regressors are not in logarithmic terms because of the existence of negative values in the panel time series, due to which the series could not be transformed into logarithmic ones.

Source: Author's calculations. equation is with fixed effects. The panel time series used the annual data. The cointegration model was estimated for the entire sample period (2000-2017), as well as for the subperiod (2008-2017). The FMOLS model with constant parameters is estimated, using only the constant as a specific trend regresor in the cross section data. For estimating the cointegration equation by means of a dynamic model of the ordinary last squares (DOLS), a constant is used as a deterministic component. The results in Table 2 show that the observed determinants have a long-term impact on the current account of peripheral eurozone members (the GAP variable represents the impact of the business cycle). The estimated coefficients with FMOLS estimators over the entire period 2000-2017 are statistically significant at the level of $1 \%$ for all regressors, except for the remittances the level of $10 \%$ ). The signs of the estimated regression coefficients are in line with theoretical expectations. The real effective exchange rate variable (logarithmic value) is included in the regression equation with a time lag and shows a negative impact on the current account due to the appreciation of the real exchange rate. The negative sign with the variable fiscal balance shows that the fiscal deficit in the period up to 2008 contributed to the worsening in the current account balance of the observed countries. A positive sign with a lagged variable of net foreign assets confirmed the theoretical attitude that income from foreign funds in open economies increases during time, which in turn reduces imports. The estimated value of the output gap coefficient has a negative sign, which shows that the growth of economic activity in the peripheral euro area members implies an increase in imports, which is negative for the current account balance. The positive sign with the saving-investment gap variable is in favor of the thesis that the growth of savings result in a positive impact on the current account balance in the observed set of countries. The growth of savings is a result of remittances, and a positive sign with this variable confirms their contribution. The estimated coefficient for the lagged variable of current account (CA (-1)) confirms the persistence of the current account deficit of the peripheral eurozone members. Similar estimates can be made based on the quantitative values of the coefficients from the estimated cointegration equation using the DOLS estimator. However, the coefficient with the fiscal balance is not statistically significant, while the majority of other coefficients are 
koeficijenti ocenjeni pomoću FMOLS estimatora su statistički signifikantni na nivou od 1\%, a u pojedinim slučajevima predznaci se razlikuju u odnosu na ceo posmatrani period (predznaci uz strane direktne investicije i fiskalni bilans su pozitivni i pokazuju da su ove promenljive delovale na smanjivanje deficita tekućeg računa). Ocenjeni koeficijent uz varijablu štednjainvesticije je pozitivan i statistički signifikantan na nivou od $1 \%$, kako u celom razdoblju tako i u posmatranom potperiodu. Rast štednje i usporenije investiranje u perifernim članicama evrozone su doprineli smanjivanju deficita tekućeg računa.

Posle ocene kointegracione jednačine testirali smo dobijene reziduale. Korišćeni su isti testovi kao i prilikom provere postojanja jediničnog korena u vremenskim serijama panela. Svi testovi su potvrdili stacionarnost reziduala. Testovi koji poseduju opciju isključivanja konstante (LLC, ADF Fisher i PP Fisher) su pokazali stacionarnost reziduala na nivou značajnosti od 1\%, kad se isključi konstanta (metodološki je pravilno isključiti konstantu prilikom utvrđivanja stacionarnosti reziduala). Na osnovu dobijenih rezultata ovih testova nameće se zaključak da su makroekonomske varijable obuhvaćene ovom analizom kointegrisane. Iz toga sledi da izabrane objašnjavajuće promenljive dobro objašnjavaju prosečno stanje tekućeg računa perifernih članica evrozone.

Ocenjeni vremenski interval 2008-2017. godine može se iskoristiti za proveru robustnosti dobijenih ocena za celo razdoblje 2000-2017. godine. Mada postoje neznatne razlike $u$ pogledu statističke signifikantnosti ocenjenih koeficijenta uz primenu DOLS estimatora, dobijeni predznaci su slični za obe panel serije. Karakteristično je da su ocenjeni koeficijenti ispred svih varijabli uz pomoć FMOLS estimatora bili statistički značajni na nivou od $1 \%$, i da su svi imali očekivane predznake. Koeficijent uz strane direktne investicije za celo razdoblje nije bio statistički signifikantan uz korišćenje FMOLS estimatora, ali je uz primenu DOLS estimatora ovaj koeficijent bio statistički značajan, sa negativnim predznakom. U potperiodu 2008-2017. ovaj pokazatelj je bio statistički signifikantan za ocenjene vrednosti pomoću FMOLS estimatora, dok je izostala signifikantnost po oceni DOLS estimatora. Ocenjeni koeficijenti za realni efektivni devizni kurs su bili statistički značajni za celo razdoblje i u posmatranom potperiodu, uz primenu estimatora FMOLS. Negativan predznak ovog koeficijenta pokazuje da je apresijacija realnog efektivnog deviznog kursa u perifernim članicama evrozone smanjivala njihovu konkurentnost, sa negativnim efektom na tekući bilans.

Tabela 3. pokazuje rezultate primene različitih estimatora obične $\mathrm{AR}(2)$ regresije CA bilansa (eng. autoregression model - AR). Na osnovu njih se može zaključiti da postoji persistentnost $C A$ računa $u$ perifernim članicama evrozone.

Tabela 3. Perzistentnost bilansa tekućeg računa - rezultati za AR(2) proces, 20002017. godina

\begin{tabular}{|l|c|c|c|c|}
\hline & PLS $^{1}$ & FMOLS $^{2}$ & DOLS $^{3}$ & RLS $^{4}$ \\
\hline \multirow{2}{*}{ CA(-1) } & 0,79 & 0,84 & 0,79 & 0,25 \\
& $(0,00)$ & $(0,00)$ & $(0,00)$ & $(0,00)$ \\
\hline \multirow{2}{*}{ CA(-2) } & 0,10 & 0,07 & 0,10 & $-0,32$ \\
& $(0,52)$ & $(0,54)$ & $(0,55)$ & $(0,00)$ \\
\hline
\end{tabular}

(1) Panel metod najmanjih kvadrata (Panel Least Squares PLS), fiksni efekti, (2) Modifikovan metod najmanjih kvadrata (Panel Fully Modified Ordinary Least Squares - FMOLS), deteretminisana kointegraciona jednačina: C), (3) Dinamički panel najmanjih kvadrata (Panel Dynamic Least Squares DOLS), deteretminisana kointegraciona jednačina: C), (4) Robustni metod najmanjih kvadrata (Robust Least Squares RLS; M-estimation).

Izvor: Proračuni autora.

Podaci u tabeli 3. su PLS, FMOLS, DOLS i RLS ocene kointegracione jednačine za tekući račun sa docnjom. Koeficijenti sa docnjom prvog reda su statistički signifikantni na nivou od $1 \%$, dok koeficijenti sa docnjom drugog reda nisu statistički signifikantni za estimatore PLS, FMOLS i DOLS. Dakle, podaci na nivou prve docnje potvrđuju perzistentnost deficita tekućeg računa.

$\mathrm{U}$ cilju dodatne provere robustnosti dobijenih koeficijenata, ocenjena je kointegraciona jednačina uključivanjem novih varijabli (DUMMY, DC i REGULAT). U tabeli 4. se daje uporedni prikaz ocenjenih koeficijenta proširene kointegracione jednačine, pri čemu se FMOLS i DOLS koriste kao estimatori. 
significant at the level of $1 \%$ (coefficients for net foreign assets and lag of one period, and the logarithmic value of foreign direct investment, also with a lag of one period, are statistically significant at the level of $5 \%$ ). In the period after the outbreak of the global financial crisis (2008-2017), all the coefficients estimated with the FMOLS estimator are statistically significant at the level of $1 \%$, and in some cases, the signs are different in relation to the entire observed period (the signs with foreign direct investment and the fiscal balance are positive and show that these variables have contributed to reducing the current account deficit). The estimated coefficient in respect of the savings-investment variable is positive and statistically significant at the level of $1 \%$, both throughout the sample period and in the observed subperiod. The growth of savings and slower investments in the periphery members of the euro area contributed to a reduction in the current account deficit.

After the estimation of the cointegration equation, the obtained residues were tested. The same tests were used as when checking the existence of a unit root in the panel time series. All tests confirmed the stationarity of residuals. Tests that have the option to exclude the constants (LLC, ADF Fisher and PP Fisher) have shown stationarity of residuals at the significance level of $1 \%$, when the constant is turned off (it is methodologically corect to exclude the constant when determining residual stationarity). Based on the obtained results of these tests, it is concluded that the macroeconomic variables covered by this analysis are co-integrated. It follows that the selected explanatory variables clearly explain the average balance of the current account of the peripheral eurozone members.

The estimated time interval 2008-2017 can be used to check the robustness of the obtained estimates for the sample period 2000-2017. Although there are slight differences in terms of the statistical significance of the estimated coefficient with the application of the DOLS estimator, the obtained signs are similar for both panel series. It is characteristic that the estimated coefficients with all variables with the FMOLS estimator were statistically significant at the level of $1 \%$, and that all of them had the expected sign. The coefficient in respect of foreign direct investment for the sample period was not statistically significant with the use of the FMOLS estimator, but with the application of the DOLS estimator this coefficient was statistically significant, with a negative sign.

In the subperiod 2008-2017, this indicator was statistically significant for the estimated values with the FMOLS estimator, while the significance according to the DOLS estimator was missing. Estimated coefficients for the real effective exchange rate were statistically significant for the whole period and in the observed subperiod, with the application of the FMOLS estimator. The negative sign of this coefficient shows that the real effective exchange rate appreciation in the periphery eurozone members diminished their competitiveness, with a negative effect on the current balance.

Table 3 shows the results of applying different estimators of regular $\mathrm{AR}(2)$ regression of the CA balance (autoregression model - AR). Based on them, it can be concluded that there are persistent $\mathrm{CA}$ accounts in the peripheral eurozone members.

Table 3. Persistence of the current account balance - results for AR (2) process, 20002017

\begin{tabular}{|l|c|c|c|c|}
\hline & PLS $^{1}$ & FMOLS $^{2}$ & DOLS $^{3}$ & RLS $^{4}$ \\
\hline \multirow{2}{*}{ CA(-1) } & 0.79 & 0.84 & 0.79 & 0.25 \\
& $(0.00)$ & $(0.00)$ & $(0.00)$ & $(0.00)$ \\
\hline \multirow{2}{*}{ CA(-2) } & 0.10 & 0.07 & 0.10 & -0.32 \\
& $(0.52)$ & $(0.54)$ & $(0.55)$ & $(0.00)$ \\
\hline
\end{tabular}

(1) Panel Least Squares (PLS), fixed effects, (2) Panel Fully Modified Ordinary Least Squares (FMOLS), Determined Cointegration Equation: C), (3) Dynamic panel of the least squares (Panel Dynamic Least Squares - DOLS), Determined Cointegration Equation: C), (4) Robust Least Squares (RLS; M-estimation).

Source: Author's calculations.

The data in Table 3 are PLS, FMOLS, DOLS and RLS estimates of the cointegration equation for a current account with a lag. The coefficients with one lag are statistically significant at the level of $1 \%$, while coefficients with two lags are not statistically significant for PLS, FMOLS and DOLS estimators. Therefore, the data at the level of one lag confirm the persistence of the current account deficit.

In order to further check the robustness of the obtained coefficients, a cointegration equation is estimated by including new 
Tabela 4. Provera robustnosti ocenjenih koeficijenata za period 2000-2017. godine (ocene pomoću FMOLS i DOLS estimatora)

\begin{tabular}{|c|c|c|c|c|c|}
\hline Varijable & & 1 & 2 & 3 & 4 \\
\hline \multirow{2}{*}{ Tekući račun - CA(-1) } & FMOLS & $0,27^{* * *}$ & $0,21^{* * *}$ & $0,16^{* * *}$ & $0,16^{* * *}$ \\
\hline & DOLS & $0,26^{* * *}$ & $0,21^{* * *}$ & $0,16^{*}$ & $0,17^{* *}$ \\
\hline \multirow{2}{*}{$\begin{array}{l}\text { Strane direktne } \\
\text { investicije - LOGFDI(-1) }\end{array}$} & FMOLS & $-8,86^{* * *}$ & $-8,94^{* * *}$ & $-10,80^{* * *}$ & $-15,23^{* * *}$ \\
\hline & DOLS & $-8,41^{* *}$ & $-7,24^{* *}$ & $-8,50^{* * *}$ & $-8,78^{* * *}$ \\
\hline \multirow{2}{*}{ Fiskalni bilans - FIS } & FMOLS & $-0,07^{* *}$ & $-0,07^{* * *}$ & $-0,04^{* * *}$ & $-0,01$ \\
\hline & DOLS & $-0,03$ & $-0,03$ & $-0,02$ & 0,01 \\
\hline \multirow{2}{*}{ Proizvodni jaz - GAP } & FMOLS & $-0,10^{* * *}$ & $-0,15^{* * *}$ & $-0,15^{* * *}$ & $-0,15^{* * *}$ \\
\hline & DOLS & $-0,15^{* *}$ & $-0,17^{* * *}$ & $-0,19^{* * *}$ & $-0,19^{* * *}$ \\
\hline \multirow{2}{*}{$\begin{array}{l}\text { Realni efektivni devizni } \\
\text { kurs - LOGREER(-1) }\end{array}$} & FMOLS & $-9,92^{* * *}$ & $-6,89 * * *$ & $-3,97^{* * *}$ & $-0,12$ \\
\hline & DOLS & $-9,02^{* * *}$ & $-5,75^{*}$ & $-2,58$ & $-2,25$ \\
\hline \multirow{2}{*}{ Doznake - REM } & FMOLS & $-0,54$ & 0,60 & $-0,53^{*}$ & $-0,71^{*}$ \\
\hline & DOLS & 0,44 & 1,67 & 1,37 & 1,35 \\
\hline \multirow{2}{*}{$\begin{array}{l}\text { Neto inostrana aktiva - } \\
\text { NFA }(-1)\end{array}$} & FMOLS & $-0,01^{*}$ & $-0,00$ & $-0,01$ & $-0,01^{* *}$ \\
\hline & DOLS & 0,00 & 0,01 & 0,02 & 0,01 \\
\hline \multirow{2}{*}{ Jaz štednje i investicija } & FMOLS & $0,73^{* * *}$ & $0,81^{* * *}$ & $0,84^{* * *}$ & $0,86^{* * *}$ \\
\hline & DOLS & $0,72^{* * *}$ & $0,83^{* * *}$ & $0,83^{* * *}$ & $0,86^{* * *}$ \\
\hline \multirow{2}{*}{ DUMMY } & FMOLS & & $-0,83^{* * *}$ & $-0,50 * * *$ & $-0,10$ \\
\hline & DOLS & & $-0,92^{* *}$ & $-0,68^{*}$ & $-0,49$ \\
\hline \multirow{2}{*}{ DC } & FMOLS & & & $-0,02^{* * *}$ & $-0,01^{* * *}$ \\
\hline & DOLS & & & $-0,02$ & $-0,01$ \\
\hline \multirow{2}{*}{ REGULAT } & FMOLS & & & & $1,99 * * *$ \\
\hline & DOLS & & & & 1,07 \\
\hline
\end{tabular}

Napomene: *** signifikantnost na nivou od 1\%, ** signifikantnost na nivou od 5\%, ${ }^{*}$ signifikantnost na nivou od $10 \%$. Panel metod: Pooled ocena.

Izvor: Proračun autora.
U koloni 1 tabele 4 . su date ocene kointegracionog vektora dobijene pomoći FMOLS i DOLS estimatora. Nekoliko dodatnih varijabli (veštačka promenljiva DUMMY, domaći krediti privatnom sektoru - DC, i veštačka varijabla REGULAT) uključeno je u kointegracionujednačinu, anjihoveocenesu date u kolonama 2, 3 i 4 . Ove varijable su uključene da bi se proverila prilagođenost izabranog modela. Koeficijenti u koloni 2, ocenjeni pomoću FMOLS estimatora, su statistički signifikantni u rasponu od 1 do $10 \%$ (izuzetak je koeficijent uz doznake koji nije statistički signifikantan). Međutim, nekoliko koeficijenata (uz fiskalni bilans, doznake i neto inostranu aktivu) nije bilo signifikantno uz primenu DOLS estimatora. Posle uvođenja varijable domaći krediti odobreni privatnom sektoru - DC, svi koeficijenti ocenjeni pomoću FMOLS estimatora su statistički signifikantni, osim koeficijenta uz varijablu neto inostrana aktiva. Uvođenje veštačke varijable REGULAT (promenljiva koja ima zadatak da oceni kvalitet institucija u jednoj zemlji) nije doprinelo povećanju robustnosti modela. Ocenjeni koeficijenti uz varijablu fiskalni bilans su bili statistički signifikantni sve do uvođenja dodatne promen $1 \mathrm{j}$ ive R E G U L A T . Zanimljivo je da koeficijent uz fiskalni deficit ima negativan predznak, što indicira da sm a n jivan je fiskalnog deficita $\mathrm{u}$ perifernim č 1 a $\mathrm{n} \mathrm{i} \mathrm{c} \mathrm{a} \mathrm{m} \mathrm{a}$ evrozone $u$ periodu posle 2008. nije uticalo na smanjivanje deficita tekućeg računa. Ocenjeni koeficijenti uz varijablu koja reprezentuje kredite odobrene privatnom sektoru (promenljiva DC) su statistički signifikantni uz primenu FMOLS estimatora. Provera robustnosti primenjenog modela je potvrdila njegovu adekvatnost.

\section{Zaključak}

U ovom radu je ocenjen uticaj izabranih faktora na kreiranje deficita tekućeg računa perifernih članica evrozone. U uzorku se nalazi pet zemalja (Italija, Španija, Portugalija, Irska i Grčka). Posmatran je vremenski period 2000-2017. godina. Cilj istraživanja je da pruži robustne ocene dugoročne veze između salda tekućeg računa i objašnjavajućih varijabli. Primenjena je panel analiza. Pošto panel vremenske serije izabranih makroekonomskih varijabli nisu bile stacionarne, primenjeno je nekoliko testova (Kao, 1999; Pedroni, 1999) koji su imali zadatak da utvrde da li postoji kointegracija polaznih panel vremenskih serija. Testovi su potvrdili postojanje kointegracije. Zatim je ocenjena kointegraciona jednačina pomoću FMOLS i DOLS estimatora. Na osnovu dobijenih rezultata moguće je zaključiti 
variables (DUMMY, DC and REGULAT). Table 4 gives a comparative overview of the estimated coefficient of the extended cointegration equation, with FMOLS and DOLS estimators.

Column 1 of Table 4 features the estimates of

all the coefficients estimated with the FMOLS estimator are statistically significant, apart from the coefficient in respect of the net foreign assets variable.

The introduction of a dummy variable REGULAT (a

Table 4. Checking the robustness of the estimated coefficients for the period 2000-2017 (estimates with FMOLS and DOLS estimators)

\begin{tabular}{|c|c|c|c|c|c|}
\hline Variable & & 1 & 2 & 3 & 4 \\
\hline \multirow{2}{*}{$\begin{array}{l}\text { Current Account - CA } \\
(-1)\end{array}$} & FMOLS & $0.27^{* * *}$ & $0.21^{* * *}$ & $0.16^{* * *}$ & $0.16^{* * *}$ \\
\hline & DOLS & $0.26^{* * *}$ & $0.21^{* * *}$ & $0.16^{*}$ & $0.17^{* *}$ \\
\hline \multirow{2}{*}{$\begin{array}{l}\text { Foreign Direct } \\
\text { Investment - } \\
\text { LOGFDI(-1) } \\
\end{array}$} & FMOLS & $-8.86^{* * *}$ & $-8.94^{* * *}$ & $-10.80^{* * *}$ & $-15.23^{* * *}$ \\
\hline & DOLS & $-8.41^{* *}$ & $-7.24^{* *}$ & $-8.50^{* * *}$ & $-8.78^{* * *}$ \\
\hline \multirow{2}{*}{ Fiscal balance - FIS } & FMOLS & $-0.07^{* *}$ & $-0.07^{* * *}$ & $-0.04^{* * *}$ & -0.01 \\
\hline & DOLS & -0.03 & -0.03 & -0.02 & 0.01 \\
\hline \multirow{2}{*}{ Output gap - GAP } & FMOLS & $-0.10^{* * *}$ & $-0.15^{* * *}$ & $-0.15^{* * *}$ & $-0.15^{* * *}$ \\
\hline & DOLS & $-0.15^{* *}$ & $-0.17^{* * *}$ & $-0.19^{* * *}$ & $-0.19^{* * *}$ \\
\hline \multirow{2}{*}{$\begin{array}{l}\text { Real Effective Exchange } \\
\text { Rate - LOGREER (-1) }\end{array}$} & FMOLS & $-9.92^{* * *}$ & $-6.89^{* * *}$ & $-3.97^{* * *}$ & -0.12 \\
\hline & DOLS & $-9.02^{* * *}$ & $-5.75^{*}$ & -2.58 & -2.25 \\
\hline \multirow{2}{*}{ Remittances - REM } & FMOLS & -0.54 & 0.60 & $-0.53^{*}$ & $-0.71^{*}$ \\
\hline & DOLS & 0.44 & 1.67 & 1.37 & 1.35 \\
\hline \multirow{2}{*}{$\begin{array}{l}\text { Net foreign assets - } \\
\text { NFA }(-1)\end{array}$} & FMOLS & $-0.01^{*}$ & -0.00 & -0.01 & $-0.01^{* *}$ \\
\hline & DOLS & 0.00 & 0.01 & 0.02 & 0.01 \\
\hline \multirow{2}{*}{ Saving-Investment Gap } & FMOLS & $0.73^{* * *}$ & $0.81^{* * *}$ & $0.84^{* * *}$ & $0.86^{* * *}$ \\
\hline & DOLS & $0.72^{* * *}$ & $0.83^{* * *}$ & $0.83^{* * *}$ & $0.86^{* * *}$ \\
\hline \multirow{2}{*}{ DUMMY } & FMOLS & & $-0.83^{* * *}$ & $-0.50^{* * *}$ & -0.10 \\
\hline & DOLS & & $-0.92^{* *}$ & $-0.68^{*}$ & -0.49 \\
\hline \multirow{2}{*}{ DC } & FMOLS & & & $-0.02^{* * *}$ & $-0.01^{* * *}$ \\
\hline & DOLS & & & -0.02 & -0.01 \\
\hline \multirow{2}{*}{ REGULAT } & FMOLS & & & & $1.99^{* * *}$ \\
\hline & DOLS & & & & 1.07 \\
\hline
\end{tabular}

Notes: ${ }^{* * *}$ significance at the level of $1 \%,{ }^{* *}$ significance at the level of $5 \%,{ }^{*}$ significance at the level of $10 \%$. Panel Method: Pooled Score.

Source: Authors' calculation.

the cointegration vector obtained by the FMOLS and DOLS estimators. Several additional variables (artificial variable DUMMY, domestic credits to the private sector - DC, and artificial variable REGULAT) are included in the cointegration equation, and their estimates are given in columns 2,3 , and 4 . These variables are included to check the suitability of the selected model.

The coefficients in column 2, which are estimated with the FMOLS estimator, are statistically significant in the range of $1 \%$ to $10 \%$ (the exception is the coefficient in respect of remittances which is not statistically significant). However, several coefficients (fiscal balance, remittances and net foreign assets) were not significant with the application of DOLS estimators. After the introduction of the variable domestic credits approved to the private sector - DC, variable that has the task to assess the quality of institutions in one country) did not contribute to increasing the robustness of the model. The estimated coefficients in respect of the fiscal balance variable were statistically significant until the introduction of the additional variable REGULAT. It is interesting that the fiscal deficit coefficient has a negative sign, which indicates that the reduction of the fiscal deficit in the peripheral members of the eurozone in the period after 2008 did not affect the reduction of the current account deficit. The estimated coefficients for a variable that represents loans to the private sector (the DC variable) are statistically significant with the application of the FMOLS estimator. Checking the robustness of the applied model has confirmed its adequacy.

\section{Conclusion}

The paper estimates the influence of the selected factors on the creation of the current account deficit in the peripheral eurozone members. There are five countries in the sample (Italy, Spain, Portugal, Ireland and Greece). The observed time period is 2000-2017. The aim of the research is to provide the robust estimates of the long-term relationship between the current 
da periferne članice evrozone karakteriše perzistentnost tekućeg računa. Strane direktne investicije igraju značajnu ulogu u pokriću ovog deficita. Zahvaljujući njihovom prilivu, posmatrane zemlje održavaju zadovoljavajuću izvoznu dinamiku. Porast stopa stranih direktnih investicija vremenom dovodi do rastućeg deficita u računu primarnog dohotka platnog bilansa, i vrši dodatni pritisak na tekući račun. Negativan predznak ispred koeficijenta uz neto inostranu aktivu pokazuje da iznenadni preokreti u tokovima kapitala mogu ugroziti održivost deficita tekućeg računa ovih zemalja. Nagli prekid neto priliva kapitala može dovesti do porasta javnog duga koji treba da supstituiše manjak priliva privatnog kapitala. Ocenjeni koeficijenti uz varijablu deviznog kursa potvrđuju da apresijacija realnog efektivnog deviznog kursa doprinosi povećanju deficita tekućeg računa kod zemalja $\mathrm{u}$ analiziranom uzorku. Gubitak konkurentnosti po ovom osnovu dugoročno nepovoljno deluje na tekući račun i zahteva strukturne zahvate u privredi. Unutrašnja devalvacija, kroz smanjivanje nadnica, mogla bi da omogući realokaciju resursa iz sektora koji ne izvoze $\mathrm{u}$ pravcu izvoznih sektora i ojača izvoznu konkurentnost ovih zemalja. To se posebno odnosi na periferne članice čiji su jedinični troškovi rada iznad istovetnih troškova glavnih trgovinskih partnera. Ovi troškovi su ujedno značajan uvozni faktor. Ograničenje naše analize je kratak vremenski horizont posmatranja, što umanjuje kvalitet ekonometrijskih ocena. 
account balance and the explanatory variables. Panel analysis was applied. Since the panel time series of the selected macroeconomic variables were not stationary, several tests (Kao, 1999; Pedroni, 1999) were applied with the task to determine whether there is a cointegration of the starting panel time series. The tests confirmed the existence of cointegration. The cointegration equation was then estimated using the FMOLS and DOLS estimators. On the basis of the results obtained, it can be concluded that the peripheral eurozone members are characterized by the current account persistence. Foreign direct investment plays an important role in covering this deficit. Thanks to the FDI inflow, the countries under review maintain a satisfactory export dynamics. The increase in the rate of foreign direct investment leads to a rising deficit in the primary income of balance of payments account, causing additional pressure on the current account. The negative sign in front of the coefficient on the foreign assets shows that sudden turnarounds in capital flows can endanger the sustainability of the current account deficit of these countries. A sudden breakdown of net capital inflows can lead to an increase in public debt that should compensate for a shortfall in private capital inflows. The estimated coefficients on the exchange rate variable confirm that a real effective exchange rate appreciation contributes to an increase in the current account deficit of the periphery countries sample. The loss of competitiveness on this basis in the long-term adversely affects the current account and requires structural interventions in the economy. The internal devaluation, through a reduction in wages, could enable a reallocation of resources from non-tradable to tradable sectors, thus strengthening the export competitiveness of these countries. This particularly applies to peripheral members whose unit labor costs are above the identical costs of its main trading partners. At the same time, these costs are a significant factor in imports. The limitation of this paper's analysis are the short time horizons, which diminish the quality of econometric estimates. 


\section{Prilog}

Tabela A: Rezultati testova jediničnog korena u panelu perifernih članica evrozone za period 20002017. godine

\begin{tabular}{|c|c|c|c|c|c|c|c|}
\hline Varijable & Metod & & $\begin{array}{l}\text { Deterministička } \\
\text { komponenta }\end{array}$ & Statistika & Verovatnoća* & $\begin{array}{l}\text { Broj } \\
\text { posm. }\end{array}$ & $\begin{array}{l}\text { Nestacionarnost } \\
\text { (NS) ili } \\
\text { stacionarnost (S) }\end{array}$ \\
\hline \multirow[t]{24}{*}{ CA } & \multirow[t]{4}{*}{ LLC } & \multirow[t]{2}{*}{ Nivo } & Konstanta & 1,27 & 0,90 & 82 & NS \\
\hline & & & Konstanta i trend & $-0,53$ & 0,27 & 80 & NS \\
\hline & & \multirow{2}{*}{$\begin{array}{l}\text { Prva } \\
\text { diferenca }\end{array}$} & Konstanta & $-4,68$ & 0,00 & 80 & $S$ \\
\hline & & & Konstanta i trend & $-2,26$ & 0,01 & 78 & $S$ \\
\hline & \multirow[t]{4}{*}{ IPS W-stat. } & \multirow[t]{2}{*}{ Nivo } & Konstanta & 1,43 & 0,92 & 82 & NS \\
\hline & & & Konstanta i trend & 0,82 & 0,80 & 80 & NS \\
\hline & & \multirow{2}{*}{$\begin{array}{l}\text { Prva } \\
\text { diferenca }\end{array}$} & Konstanta & $-5,96$ & 0,00 & 80 & $S$ \\
\hline & & & Konstanta i trend & $-2,20$ & 0,01 & 78 & $S$ \\
\hline & \multirow{4}{*}{\begin{tabular}{|l} 
ADF- \\
Fisher \\
Chi- \\
squared
\end{tabular}} & \multirow[t]{2}{*}{ Nivo } & Konstanta & 3,72 & 0,96 & 82 & NS \\
\hline & & & Konstanta i trend & 4,77 & 0,91 & 80 & NS \\
\hline & & \multirow{2}{*}{$\begin{array}{l}\text { Prva } \\
\text { diferenca }\end{array}$} & Konstanta & 39,28 & 0,00 & 80 & $S$ \\
\hline & & & Konstanta i trend & 19,63 & 0,03 & 78 & $S$ \\
\hline & \multirow{4}{*}{$\begin{array}{l}\text { PP-Fisher } \\
\text { Chi- } \\
\text { squared }\end{array}$} & \multirow[t]{2}{*}{ Nivo } & Konstanta & 4,52 & 0,92 & 85 & NS \\
\hline & & & Konstanta i trend & 2,78 & 0,99 & 85 & NS \\
\hline & & \multirow{2}{*}{$\begin{array}{l}\text { Prva } \\
\text { diferenca }\end{array}$} & Konstanta & 38,69 & 0,00 & 80 & $S$ \\
\hline & & & Konstanta i trend & 31,13 & 0,00 & 80 & $S$ \\
\hline & \multirow{4}{*}{$\begin{array}{l}\text { Breitung } \\
\text { t-stat. }\end{array}$} & \multirow[t]{2}{*}{ Nivo } & Konstanta & & & & \\
\hline & & & Konstanta i trend & $-0,18$ & 0,43 & 75 & NS \\
\hline & & \multirow{2}{*}{\begin{tabular}{|l} 
Prva \\
diferenca
\end{tabular}} & Konstanta & & & & \\
\hline & & & Konstanta i trend & $-4,37$ & 0,00 & 73 & $S$ \\
\hline & \multirow{4}{*}{$\begin{array}{l}\text { Hadri } \\
\text { Z-stat. }\end{array}$} & \multirow[t]{2}{*}{ Nivo } & Konstanta & 2,39 & 0,01 & 90 & NS \\
\hline & & & Konstanta i trend & 4,24 & 0,00 & 90 & NS \\
\hline & & \multirow{2}{*}{\begin{tabular}{|l|} 
Prva \\
diferenca
\end{tabular}} & Konstanta & 1,14 & 0,13 & 85 & $S$ \\
\hline & & & Konstanta i trend & 2,44 & 0,01 & 85 & NS \\
\hline \multirow[t]{24}{*}{ FIS } & \multirow[t]{4}{*}{ LLC } & Nivo & Konstanta & $-1,54$ & 0,06 & 82 & NS \\
\hline & & & Konstanta i trend & $-1,21$ & 0,11 & 82 & NS \\
\hline & & Prva & Konstanta & $-6,89$ & 0,00 & 78 & $S$ \\
\hline & & diferenca & Konstanta i trend & $-6,42$ & 0,00 & 78 & $S$ \\
\hline & IPS W - & Nivo & Konstanta & $-1,52$ & 0,06 & 82 & NS \\
\hline & stat. & & Konstanta i trend & $-0,12$ & 0,45 & 82 & NS \\
\hline & & Prva & Konstanta & $-5,01$ & 0,00 & 78 & $S$ \\
\hline & & diferenca & Konstanta i trend & $-3,86$ & 0,00 & 78 & $S$ \\
\hline & ADF- & Nivo & Konstanta & 17,93 & 0,06 & 82 & NS \\
\hline & Fisher & & Konstanta i trend & 10,27 & 0,41 & 82 & NS \\
\hline & Chi- & Prva & Konstanta & 41,52 & 0,00 & 78 & $S$ \\
\hline & squared & diferenca & Konstanta i trend & 31,33 & 0,00 & 78 & $S$ \\
\hline & PP-Fisher & Nivo & Konstanta & 11,31 & 0,33 & 85 & NS \\
\hline & Chi- & & Konstanta i trend & 5,76 & 0,84 & 85 & NS \\
\hline & squared & Prva & Konstanta & 49,54 & 0,00 & 80 & $S$ \\
\hline & & diferenca & Konstanta i trend & 37,57 & 0,00 & 80 & $S$ \\
\hline & Breitung & Nivo & Konstanta & & & & \\
\hline & & & Konstanta i trend & $-0,74$ & 0,23 & 77 & NS \\
\hline & & Prva & Konstanta & & & & \\
\hline & & diferenca & Konstanta i trend & $-5,31$ & 0,00 & 73 & $S$ \\
\hline & Hadri & Nivo & Konstanta & 0,95 & 0,17 & 90 & $S$ \\
\hline & Z-stat. & & Konstanta i trend & 3,10 & 0,00 & 90 & NS \\
\hline & & Prva & Konstanta & 0,02 & 0,49 & 85 & $S$ \\
\hline & & diferenca & Konstanta i trend & 0,95 & 0,17 & 85 & $S$ \\
\hline
\end{tabular}




\section{Annex}

Table A: Results of the unit root tests in the panel of peripheral eurozone members for the period 2000-2017

\begin{tabular}{|c|c|c|c|c|c|c|c|}
\hline Variable & Method & & $\begin{array}{l}\text { Deterministic } \\
\text { terms }\end{array}$ & Statistics & Prob.* & Obs. & $\begin{array}{c}\text { Non Stationary } \\
\text { (NS) Stationary } \\
\text { (S) }\end{array}$ \\
\hline \multirow[t]{24}{*}{$\mathrm{CA}$} & \multirow[t]{4}{*}{ LLC } & \multirow[t]{2}{*}{ Level } & Constant & 1.27 & 0.90 & 82 & NS \\
\hline & & & Constant and trend & -0.53 & 0.27 & 80 & NS \\
\hline & & \multirow{2}{*}{\begin{tabular}{|l|} 
First \\
Difference
\end{tabular}} & Constant & -4.68 & 0.00 & 80 & $S$ \\
\hline & & & Constant and trend & -2.26 & 0.01 & 78 & $S$ \\
\hline & \multirow{4}{*}{\begin{tabular}{|l} 
IPS \\
W-stat.
\end{tabular}} & \multirow[t]{2}{*}{ Level } & Constant & 1.43 & 0.92 & 82 & NS \\
\hline & & & Constant and trend & 0.82 & 0.80 & 80 & NS \\
\hline & & \multirow{2}{*}{\begin{tabular}{|l} 
First \\
Difference
\end{tabular}} & Constant & -5.96 & 0.00 & 80 & $S$ \\
\hline & & & Constant and trend & -2.20 & 0.01 & 78 & $S$ \\
\hline & \multirow{4}{*}{\begin{tabular}{|l} 
ADF- \\
Fisher \\
Chi- \\
squared
\end{tabular}} & \multirow[t]{2}{*}{ Level } & Constant & 3.72 & 0.96 & 82 & NS \\
\hline & & & Constant and trend & 4.77 & 0.91 & 80 & NS \\
\hline & & \multirow{2}{*}{$\begin{array}{l}\text { First } \\
\text { Difference }\end{array}$} & Constant & 39.28 & 0.00 & 80 & $S$ \\
\hline & & & Constant and trend & 19.63 & 0.03 & 78 & $S$ \\
\hline & \multirow{4}{*}{$\begin{array}{l}\text { PP-Fisher } \\
\text { Chi- } \\
\text { squared }\end{array}$} & \multirow[t]{2}{*}{ Level } & Constant & 4.52 & 0.92 & 85 & NS \\
\hline & & & Constant and trend & 2.78 & 0.99 & 85 & NS \\
\hline & & \multirow{2}{*}{$\begin{array}{l}\text { First } \\
\text { Difference }\end{array}$} & Constant & 38.69 & 0.00 & 80 & $S$ \\
\hline & & & Constant and trend & 31.13 & 0.00 & 80 & $S$ \\
\hline & \multirow{4}{*}{$\begin{array}{l}\text { Breitung } \\
\text { t-stat. }\end{array}$} & \multirow[t]{2}{*}{ Level } & Constant & & & & \\
\hline & & & Constant and trend & -0.18 & 0.43 & 75 & NS \\
\hline & & \multirow{2}{*}{\begin{tabular}{|l} 
First \\
Difference
\end{tabular}} & Constant & & & & \\
\hline & & & Constant and trend & -4.37 & 0.00 & 73 & $S$ \\
\hline & \multirow{4}{*}{$\begin{array}{l}\text { Hadri } \\
\text { Z-stat. }\end{array}$} & \multirow[t]{2}{*}{ Level } & Constant & 2.39 & 0.01 & 90 & NS \\
\hline & & & Constant and trend & 4.24 & 0.00 & 90 & NS \\
\hline & & \multirow{2}{*}{\begin{tabular}{|l} 
First \\
Difference
\end{tabular}} & Constant & 1.14 & 0.13 & 85 & $S$ \\
\hline & & & Constant and trend & 2.44 & 0.01 & 85 & NS \\
\hline \multirow[t]{24}{*}{ FIS } & \multirow[t]{4}{*}{ LLC } & Level & Constant & -1.54 & 0.06 & 82 & NS \\
\hline & & & Constant and trend & -1.21 & 0.11 & 82 & NS \\
\hline & & First & Constant & -6.89 & 0.00 & 78 & $S$ \\
\hline & & Difference & Constant and trend & -6.42 & 0.00 & 78 & $S$ \\
\hline & IPS W - & Level & Constant & -1.52 & 0.06 & 82 & NS \\
\hline & stat. & & Constant and trend & -0.12 & 0.45 & 82 & NS \\
\hline & & First & Constant & -5.01 & 0.00 & 78 & $S$ \\
\hline & & Difference & Constant and trend & -3.86 & 0.00 & 78 & $S$ \\
\hline & ADF- & Level & Constant & 17.93 & 0.06 & 82 & NS \\
\hline & Fisher & & Constant and trend & 10.27 & 0.41 & 82 & NS \\
\hline & Chi- & First & Constant & 41.52 & 0.00 & 78 & $S$ \\
\hline & squared & Difference & Constant and trend & 31.33 & 0.00 & 78 & $S$ \\
\hline & PP-Fisher & Level & Constant & 11.31 & 0.33 & 85 & NS \\
\hline & Chi- & & Constant and trend & 5.76 & 0.84 & 85 & NS \\
\hline & squared & First & Constant & 49.54 & 0.00 & 80 & $S$ \\
\hline & & Difference & Constant and trend & 37.57 & 0.00 & 80 & $S$ \\
\hline & Breitung & Level & Constant & & & & \\
\hline & & & Constant and trend & -0.74 & 0.23 & 77 & NS \\
\hline & & First & Constant & & & & \\
\hline & & Difference & Constant and trend & -5.31 & 0.00 & 73 & $S$ \\
\hline & Hadri & Level & Constant & 0.95 & 0.17 & 90 & $S$ \\
\hline & Z-stat. & & Constant and trend & 3.10 & 0.00 & 90 & NS \\
\hline & & First & Constant & 0.02 & 0.49 & 85 & $S$ \\
\hline & & Difference & Constant and trend & 0.95 & 0.17 & 85 & $S$ \\
\hline
\end{tabular}




\begin{tabular}{|c|c|c|c|c|c|c|c|}
\hline Varijable & Metod & & $\begin{array}{l}\text { Deterministička } \\
\text { komponenta }\end{array}$ & Statistika & Verovatnoća* & $\begin{array}{c}\text { Broj } \\
\text { posm. }\end{array}$ & $\begin{array}{l}\text { Nestacionarnost } \\
\text { (NS) ili } \\
\text { stacionarnost (S) }\end{array}$ \\
\hline \multirow[t]{24}{*}{ FDI } & \multirow[t]{4}{*}{ LLC } & \multirow[t]{2}{*}{ Nivo } & Konstanta & $-4,92$ & 0,00 & 85 & $S$ \\
\hline & & & Konstanta i trend & $-3,86$ & 0,00 & 81 & $S$ \\
\hline & & \multirow{2}{*}{\begin{tabular}{|l|} 
Prva \\
diferenca
\end{tabular}} & Konstanta & $-9,40$ & 0,00 & 76 & $S$ \\
\hline & & & Konstanta i trend & $-9,10$ & 0,00 & 79 & $S$ \\
\hline & \multirow{4}{*}{$\begin{array}{l}\text { IPS W - } \\
\text { stat. }\end{array}$} & \multirow[t]{2}{*}{ Nivo } & Konstanta & $-4,21$ & 0,00 & 85 & $S$ \\
\hline & & & Konstanta i trend & $-3,94$ & 0,00 & 81 & $S$ \\
\hline & & \multirow{2}{*}{$\begin{array}{l}\text { Prva } \\
\text { diferenca }\end{array}$} & Konstanta & $-8,59$ & 0,00 & 76 & $S$ \\
\hline & & & Konstanta i trend & $-7,91$ & 0,00 & 79 & $S$ \\
\hline & \multirow{4}{*}{\begin{tabular}{|l|} 
ADF- \\
Fisher \\
Chi- \\
squared
\end{tabular}} & \multirow{2}{*}{ Nivo } & Konstanta & 34,86 & 0,00 & 85 & $S$ \\
\hline & & & Konstanta i trend & 32,41 & 0,00 & 81 & $S$ \\
\hline & & \multirow{2}{*}{$\begin{array}{l}\text { Prva } \\
\text { diferenca }\end{array}$} & Konstanta & 72,89 & 0,00 & 76 & $\mathrm{~S}$ \\
\hline & & & Konstanta i trend & 59,44 & 0,00 & 79 & $S$ \\
\hline & \multirow{4}{*}{$\begin{array}{l}\text { PP-Fisher } \\
\text { Chi- } \\
\text { squared }\end{array}$} & \multirow[t]{2}{*}{ Nivo } & Konstanta & 34,70 & 0,00 & 85 & $S$ \\
\hline & & & Konstanta i trend & 33,23 & 0,00 & 85 & $\mathrm{~S}$ \\
\hline & & \multirow{2}{*}{\begin{tabular}{|l|} 
Prva \\
diferenca
\end{tabular}} & Konstanta & 153,21 & 0,00 & 80 & $S$ \\
\hline & & & Konstanta i trend & 89,66 & 0,00 & 80 & $S$ \\
\hline & \multirow[t]{4}{*}{ Breitung } & \multirow[t]{2}{*}{ Nivo } & Konstanta & & & & \\
\hline & & & Konstanta i trend & $-3,05$ & 0,00 & 76 & $S$ \\
\hline & & \multirow{2}{*}{$\begin{array}{l}\text { Prva } \\
\text { diferenca }\end{array}$} & Konstanta & & & & \\
\hline & & & Konstanta i trend & $-2,48$ & 0,01 & 74 & $S$ \\
\hline & \multirow{4}{*}{$\begin{array}{l}\text { Hadri } \\
\text { Z-stat. }\end{array}$} & \multirow[t]{2}{*}{ Nivo } & Konstanta & 1,45 & 0,07 & 90 & $S$ \\
\hline & & & Konstanta i trend & 4,19 & 0,00 & 90 & NS \\
\hline & & \multirow{2}{*}{$\begin{array}{l}\text { Prva } \\
\text { diferenca }\end{array}$} & Konstanta & 0,97 & 0,16 & 85 & $\mathrm{~S}$ \\
\hline & & & Konstanta i trend & 6,49 & 0,00 & 85 & NS \\
\hline \multirow[t]{24}{*}{ REER } & \multirow[t]{4}{*}{ LLC } & Nivo & Konstanta & $-3,72$ & 0,00 & 84 & $S$ \\
\hline & & & Konstanta i trend & $-2,39$ & 0,01 & 85 & $\mathrm{~S}$ \\
\hline & & Prva & Konstanta & $-4,75$ & 0,00 & 80 & $\mathrm{~S}$ \\
\hline & & diferenca & Konstanta i trend & $-5,13$ & 0,00 & 77 & $S$ \\
\hline & IPS W - & Nivo & Konstanta & $-2,60$ & 0,00 & 83 & $\mathrm{~S}$ \\
\hline & stat. & & Konstanta i trend & 1,22 & 0,89 & 85 & NS \\
\hline & & Prva & Konstanta & $-2,65$ & 0,00 & 80 & $\mathrm{~S}$ \\
\hline & & diferenca & Konstanta i trend & $-3,39$ & 0,00 & 77 & $\mathrm{~S}$ \\
\hline & ADF- & Nivo & Konstanta & 22,73 & 0,01 & 83 & $\mathrm{~S}$ \\
\hline & Fisher & & Konstanta i trend & 4,39 & 0,93 & 85 & NS \\
\hline & Chi- & Prva & Konstanta & 22,75 & 0,01 & 80 & $S$ \\
\hline & squared & diferenca & Konstanta i trend & 28,01 & 0,00 & 77 & $S$ \\
\hline & PP-Fisher & Nivo & Konstanta & 19,74 & 0,03 & 85 & $S$ \\
\hline & Chi- & & Konstanta i trend & 18,73 & 0,04 & 85 & $\mathrm{~S}$ \\
\hline & squared & Prva & Konstanta & 21,70 & 0,02 & 80 & $S$ \\
\hline & & diferenca & Konstanta i trend & 28,47 & 0,00 & 80 & $S$ \\
\hline & Breitung & Nivo & Konstanta & & & & \\
\hline & & & Konstanta i trend & 2,38 & 0,99 & 80 & NS \\
\hline & & Prva & Konstanta & & & & \\
\hline & & diferenca & Konstanta i trend & $-2,48$ & 0,01 & 72 & $\mathrm{~S}$ \\
\hline & Hadri & Nivo & Konstanta & 0,95 & 0,17 & 90 & $\mathrm{~S}$ \\
\hline & Z-stat. & & Konstanta i trend & 5,93 & 0,00 & 80 & NS \\
\hline & & Prva & Konstanta & 4,23 & 0,00 & 85 & NS \\
\hline & & diferenca & Konstanta i trend & 9,30 & 0,00 & 85 & NS \\
\hline
\end{tabular}




\begin{tabular}{|c|c|c|c|c|c|c|c|}
\hline Variable & Method & & $\begin{array}{l}\text { Deterministic } \\
\text { terms }\end{array}$ & Statistics & Prob.* & Obs. & $\begin{array}{c}\text { Non Stationary } \\
\text { (NS) Stationary } \\
\text { (S) }\end{array}$ \\
\hline \multirow[t]{24}{*}{ FDI } & \multirow[t]{4}{*}{ LLC } & \multirow[t]{2}{*}{ Level } & Constant & -4.92 & 0.00 & 85 & $S$ \\
\hline & & & Constant and trend & -3.86 & 0.00 & 81 & $\mathrm{~S}$ \\
\hline & & \multirow{2}{*}{$\begin{array}{l}\text { First } \\
\text { Difference }\end{array}$} & Constant & -9.40 & 0.00 & 76 & $\mathrm{~S}$ \\
\hline & & & Constant and trend & -9.10 & 0.00 & 79 & $\mathrm{~S}$ \\
\hline & \multirow{4}{*}{$\begin{array}{l}\text { IPS W - } \\
\text { stat. }\end{array}$} & \multirow[t]{2}{*}{ Level } & Constant & -4.21 & 0.00 & 85 & $\mathrm{~S}$ \\
\hline & & & Constant and trend & -3.94 & 0.00 & 81 & $\mathrm{~S}$ \\
\hline & & \multirow{2}{*}{$\begin{array}{l}\text { First } \\
\text { Difference }\end{array}$} & Constant & -8.59 & 0.00 & 76 & $\mathrm{~S}$ \\
\hline & & & Constant and trend & -7.91 & 0.00 & 79 & $\mathrm{~S}$ \\
\hline & \multirow{4}{*}{$\begin{array}{l}\text { ADF- } \\
\text { Fisher } \\
\text { Chi- } \\
\text { squared }\end{array}$} & \multirow[t]{2}{*}{ Level } & Constant & 34.86 & 0.00 & 85 & $\mathrm{~S}$ \\
\hline & & & Constant and trend & 32.41 & 0.00 & 81 & $\mathrm{~S}$ \\
\hline & & \multirow{2}{*}{$\begin{array}{l}\text { First } \\
\text { Difference }\end{array}$} & Constant & 72.89 & 0.00 & 76 & $\mathrm{~S}$ \\
\hline & & & Constant and trend & 59.44 & 0.00 & 79 & $\mathrm{~S}$ \\
\hline & \multirow{4}{*}{$\begin{array}{l}\text { PP-Fisher } \\
\text { Chi- } \\
\text { squared }\end{array}$} & \multirow[t]{2}{*}{ Level } & Constant & 34.70 & 0.00 & 85 & $\mathrm{~S}$ \\
\hline & & & Constant and trend & 33.23 & 0.00 & 85 & $\mathrm{~S}$ \\
\hline & & \multirow{2}{*}{$\begin{array}{l}\text { First } \\
\text { Difference }\end{array}$} & Constant & 153.21 & 0.00 & 80 & $\mathrm{~S}$ \\
\hline & & & Constant and trend & 89.66 & 0.00 & 80 & $\mathrm{~S}$ \\
\hline & \multirow[t]{4}{*}{ Breitung } & \multirow[t]{2}{*}{ Level } & Constant & & & & \\
\hline & & & Constant and trend & -3.05 & 0.00 & 76 & $\mathrm{~S}$ \\
\hline & & \multirow{2}{*}{$\begin{array}{l}\text { First } \\
\text { Difference }\end{array}$} & Constant & & & & \\
\hline & & & Constant and trend & -2.48 & 0.01 & 74 & $\mathrm{~S}$ \\
\hline & \multirow{4}{*}{$\begin{array}{l}\text { Hadri } \\
\text { Z-stat. }\end{array}$} & \multirow[t]{2}{*}{ Level } & Constant & 1.45 & 0.07 & 90 & $\mathrm{~S}$ \\
\hline & & & Constant and trend & 4.19 & 0.00 & 90 & NS \\
\hline & & \multirow{2}{*}{$\begin{array}{l}\text { First } \\
\text { Difference }\end{array}$} & Constant & 0.97 & 0.16 & 85 & $\mathrm{~S}$ \\
\hline & & & Constant and trend & 6.49 & 0.00 & 85 & NS \\
\hline \multirow[t]{24}{*}{ REER } & \multirow[t]{4}{*}{ LLC } & Level & Constant & -3.72 & 0.00 & 84 & $\mathrm{~S}$ \\
\hline & & & Constant and trend & -2.39 & 0.01 & 85 & $\mathrm{~S}$ \\
\hline & & & Constant & -4.75 & 0.00 & 80 & $\mathrm{~S}$ \\
\hline & & Difference & Constant and trend & -5.13 & 0.00 & 77 & $\mathrm{~S}$ \\
\hline & IPS W - & Level & Constant & -2.60 & 0.00 & 83 & $\mathrm{~S}$ \\
\hline & & & Constant and trend & 1.22 & 0.89 & 85 & NS \\
\hline & & First & Constant & -2.65 & 0.00 & 80 & $\mathrm{~S}$ \\
\hline & & Difference & Constant and trend & -3.39 & 0.00 & 77 & $\mathrm{~S}$ \\
\hline & ADF- & Level & Constant & 22.73 & 0.01 & 83 & $\mathrm{~S}$ \\
\hline & Fisher & & Constant and trend & 4.39 & 0.93 & 85 & NS \\
\hline & Chi- & First & Constant & 22.75 & 0.01 & 80 & S \\
\hline & & Difference & Constant and trend & 28.01 & 0.00 & 77 & $\mathrm{~S}$ \\
\hline & PP-Fisher & Level & Constant & 19.74 & 0.03 & 85 & $\mathrm{~S}$ \\
\hline & Chi- & & Constant and trend & 18.73 & 0.04 & 85 & $\mathrm{~S}$ \\
\hline & & First & Constant & 21.70 & 0.02 & 80 & $\mathrm{~S}$ \\
\hline & & Difference & Constant and trend & 28.47 & 0.00 & 80 & $\mathrm{~S}$ \\
\hline & Breitung & Level & Constant & & & & \\
\hline & & & Constant and trend & 2.38 & 0.99 & 80 & NS \\
\hline & & First & Constant & & & & \\
\hline & & Difference & Constant and trend & -2.48 & 0.01 & 72 & $\mathrm{~S}$ \\
\hline & Hadri & Level & Constant & 0.95 & 0.17 & 90 & $\mathrm{~S}$ \\
\hline & Z-stat. & & Constant and trend & 5.93 & 0.00 & 80 & NS \\
\hline & & & Constant & 4.23 & 0.00 & 85 & NS \\
\hline & & Differ & $\operatorname{stan}$ & 30 & 0 & 85 & NS \\
\hline
\end{tabular}




\begin{tabular}{|c|c|c|c|c|c|c|c|}
\hline Varijable & Metod & & $\begin{array}{l}\text { Deterministička } \\
\text { komponenta }\end{array}$ & Statistika & Verovatnoća* & $\begin{array}{l}\text { Broj } \\
\text { posm. }\end{array}$ & $\begin{array}{l}\text { Nestacionarnost } \\
\text { (NS) ili } \\
\text { stacionarnost (S) }\end{array}$ \\
\hline \multirow[t]{24}{*}{ SIG } & \multirow[t]{4}{*}{ LLC } & \multirow[t]{2}{*}{ Nivo } & Konstanta & 1,26 & 0,90 & 83 & NS \\
\hline & & & Konstanta i trend & 0,81 & 0,79 & 84 & NS \\
\hline & & \multirow{2}{*}{$\begin{array}{l}\text { Prva } \\
\text { diferenca }\end{array}$} & Konstanta & $-6,92$ & 0,00 & 80 & $S$ \\
\hline & & & Konstanta i trend & $-6,55$ & 0,00 & 80 & $S$ \\
\hline & \multirow{4}{*}{$\begin{array}{l}\text { IPS W - } \\
\text { stat. }\end{array}$} & \multirow[t]{2}{*}{ Nivo } & Konstanta & 2,47 & 0,99 & 83 & NS \\
\hline & & & Konstanta i trend & 1,86 & 0,97 & 84 & NS \\
\hline & & \multirow{2}{*}{$\begin{array}{l}\text { Prva } \\
\text { diferenca }\end{array}$} & Konstanta & $-5,57$ & 0,00 & 80 & $S$ \\
\hline & & & Konstanta i trend & $-4,61$ & 0,00 & 80 & $S$ \\
\hline & \multirow{4}{*}{\begin{tabular}{|l|} 
ADF- \\
Fisher \\
Chi- \\
squared
\end{tabular}} & \multirow{2}{*}{ Nivo } & Konstanta & 1,84 & 0,99 & 83 & NS \\
\hline & & & Konstanta i trend & 2,09 & 0,99 & 84 & NS \\
\hline & & \multirow{2}{*}{$\begin{array}{l}\text { Prva } \\
\text { diferenca }\end{array}$} & Konstanta & 45,54 & 0,00 & 80 & $S$ \\
\hline & & & Konstanta i trend & 35,21 & 0,00 & 80 & $S$ \\
\hline & \multirow{4}{*}{$\begin{array}{l}\text { PP-Fisher } \\
\text { Chi- } \\
\text { squared }\end{array}$} & \multirow[t]{2}{*}{ Nivo } & Konstanta & 1,66 & 0,99 & 85 & NS \\
\hline & & & Konstanta i trend & 3,16 & 0,98 & 85 & NS \\
\hline & & \multirow{2}{*}{\begin{tabular}{|l|} 
Prva \\
diferenca
\end{tabular}} & Konstanta & 43,76 & 0,00 & 80 & $S$ \\
\hline & & & Konstanta i trend & 36,98 & 0,00 & 80 & $S$ \\
\hline & \multirow[t]{4}{*}{ Breitung } & \multirow[t]{2}{*}{ Nivo } & Konstanta & & & & \\
\hline & & & Konstanta i trend & 0,10 & 0,54 & 79 & NS \\
\hline & & \multirow{2}{*}{$\begin{array}{l}\text { Prva } \\
\text { diferenca }\end{array}$} & Konstanta & & & & \\
\hline & & & Konstanta i trend & $-4,28$ & 0,00 & 75 & $S$ \\
\hline & \multirow{4}{*}{$\begin{array}{l}\text { Hadri } \\
\text { Z-stat. }\end{array}$} & \multirow[t]{2}{*}{ Nivo } & Konstanta & 3,92 & 0,00 & 90 & NS \\
\hline & & & Konstanta i trend & 4,25 & 0,00 & 90 & NS \\
\hline & & \multirow{2}{*}{$\begin{array}{l}\text { Prva } \\
\text { diferenca }\end{array}$} & Konstanta & 1,27 & 0,10 & 85 & $S$ \\
\hline & & & Konstanta i trend & 0,70 & 0,24 & 85 & $S$ \\
\hline \multirow[t]{24}{*}{ NFA } & \multirow[t]{4}{*}{ LLC } & Nivo & Konstanta & $-0,13$ & 0,41 & 78 & NS \\
\hline & & & Konstanta i trend & $-1,64$ & 0,05 & 78 & $S$ \\
\hline & & Prva & Konstanta & $-6,52$ & 0,00 & 74 & $S$ \\
\hline & & diferenca & Konstanta i trend & $-5,64$ & 0,00 & 72 & $S$ \\
\hline & IPS W - & Nivo & Konstanta & 0,16 & 0,56 & 78 & NS \\
\hline & stat. & & Konstanta i trend & 0,09 & 0,54 & 78 & NS \\
\hline & & Prva & Konstanta & $-4,03$ & 0,00 & 74 & $\mathrm{~S}$ \\
\hline & & diferenca & Konstanta i trend & $-3,11$ & 0,00 & 72 & $S$ \\
\hline & ADF- & Nivo & Konstanta & $-8,10$ & 0,62 & 78 & NS \\
\hline & Fisher & & Konstanta i trend & 7,59 & 0,67 & 78 & NS \\
\hline & Chi- & Prva & Konstanta & 33,52 & 0,00 & 74 & $S$ \\
\hline & squared & diferenca & Konstanta i trend & 25,97 & 0,00 & 72 & $S$ \\
\hline & PP-Fisher & Nivo & Konstanta & 6,93 & 0,73 & 80 & NS \\
\hline & Chi- & & Konstanta i trend & 5,01 & 0,89 & 80 & NS \\
\hline & squared & Prva & Konstanta & 33,48 & 0,00 & 75 & S \\
\hline & & diferenca & Konstanta i trend & 28,50 & 0,00 & 75 & $S$ \\
\hline & Breitung & Nivo & Konstanta & & & & \\
\hline & & & Konstanta i trend & $-0,99$ & 0,16 & 73 & NS \\
\hline & & Prva & Konstanta & & & & \\
\hline & & diferenca & Konstanta i trend & $-5,15$ & 0,00 & 67 & $S$ \\
\hline & Hadri & Nivo & Konstanta & 2,41 & 0,01 & 85 & NS \\
\hline & Z-stat. & & Konstanta i trend & 2,53 & 0,01 & 85 & NS \\
\hline & & Prva & Konstanta & 0,26 & 0,40 & 80 & $S$ \\
\hline & & diferenca & Konstanta i trend & 3,61 & 0,00 & 80 & NS \\
\hline
\end{tabular}




\begin{tabular}{|c|c|c|c|c|c|c|c|}
\hline Variable & Method & & $\begin{array}{l}\text { Deterministic } \\
\text { terms }\end{array}$ & Statistics & Prob.* & Obs. & $\begin{array}{c}\text { Non Stationary } \\
\text { (NS) Stationary } \\
\text { (S) }\end{array}$ \\
\hline \multirow[t]{24}{*}{ SIG } & \multirow[t]{4}{*}{ LLC } & \multirow[t]{2}{*}{ Level } & Constant & 1.26 & 0.90 & 83 & NS \\
\hline & & & Constant and trend & 0.81 & 0.79 & 84 & NS \\
\hline & & \multirow{2}{*}{$\begin{array}{l}\text { First } \\
\text { Difference }\end{array}$} & Constant & -6.92 & 0.00 & 80 & $S$ \\
\hline & & & Constant and trend & -6.55 & 0.00 & 80 & $\mathrm{~S}$ \\
\hline & \multirow{4}{*}{$\begin{array}{l}\text { IPS W - } \\
\text { stat. }\end{array}$} & \multirow[t]{2}{*}{ Level } & Constant & 2.47 & 0.99 & 83 & NS \\
\hline & & & Constant and trend & 1.86 & 0.97 & 84 & NS \\
\hline & & \multirow{2}{*}{$\begin{array}{l}\text { First } \\
\text { Difference }\end{array}$} & Constant & -5.57 & 0.00 & 80 & $\mathrm{~S}$ \\
\hline & & & Constant and trend & -4.61 & 0.00 & 80 & $\mathrm{~S}$ \\
\hline & \multirow{4}{*}{$\begin{array}{l}\text { ADF- } \\
\text { Fisher } \\
\text { Chi- } \\
\text { squared }\end{array}$} & \multirow[t]{2}{*}{ Level } & Constant & 1.84 & 0.99 & 83 & NS \\
\hline & & & Constant and trend & 2.09 & 0.99 & 84 & NS \\
\hline & & \multirow{2}{*}{$\begin{array}{l}\text { First } \\
\text { Difference }\end{array}$} & Constant & 45.54 & 0.00 & 80 & $\mathrm{~S}$ \\
\hline & & & Constant and trend & 35.21 & 0.00 & 80 & $\mathrm{~S}$ \\
\hline & \multirow{4}{*}{$\begin{array}{l}\text { PP-Fisher } \\
\text { Chi- } \\
\text { squared }\end{array}$} & \multirow[t]{2}{*}{ Level } & Constant & 1.66 & 0.99 & 85 & NS \\
\hline & & & Constant and trend & 3.16 & 0.98 & 85 & NS \\
\hline & & \multirow{2}{*}{$\begin{array}{l}\text { First } \\
\text { Difference }\end{array}$} & Constant & 43.76 & 0.00 & 80 & $\mathrm{~S}$ \\
\hline & & & Constant and trend & 36.98 & 0.00 & 80 & $\mathrm{~S}$ \\
\hline & \multirow[t]{4}{*}{ Breitung } & \multirow[t]{2}{*}{ Level } & Constant & & & & \\
\hline & & & Constant and trend & 0.10 & 0.54 & 79 & NS \\
\hline & & \multirow{2}{*}{$\begin{array}{l}\text { First } \\
\text { Difference }\end{array}$} & Constant & & & & \\
\hline & & & Constant and trend & -4.28 & 0.00 & 75 & $\mathrm{~S}$ \\
\hline & \multirow{4}{*}{$\begin{array}{l}\text { Hadri } \\
\text { Z-stat. }\end{array}$} & \multirow[t]{2}{*}{ Level } & Constant & 3.92 & 0.00 & 90 & NS \\
\hline & & & Constant and trend & 4.25 & 0.00 & 90 & NS \\
\hline & & \multirow{2}{*}{$\begin{array}{l}\text { First } \\
\text { Difference }\end{array}$} & Constant & 1.27 & 0.10 & 85 & $\mathrm{~S}$ \\
\hline & & & Constant and trend & 0.70 & 0.24 & 85 & $\mathrm{~S}$ \\
\hline \multirow[t]{24}{*}{ NFA } & \multirow[t]{4}{*}{ LLC } & Level & Constant & -0.13 & 0.41 & 78 & NS \\
\hline & & & Constant and trend & -1.64 & 0.05 & 78 & $\mathrm{~S}$ \\
\hline & & & Constant & -6.52 & 0.00 & 74 & $\mathrm{~S}$ \\
\hline & & Difference & Constant and trend & -5.64 & 0.00 & 72 & $\mathrm{~S}$ \\
\hline & IPS W - & Level & Constant & 0.16 & 0.56 & 78 & NS \\
\hline & & & Constant and trend & 0.09 & 0.54 & 78 & NS \\
\hline & & First & Constant & -4.03 & 0.00 & 74 & $\mathrm{~S}$ \\
\hline & & Difference & Constant and trend & -3.11 & 0.00 & 72 & $\mathrm{~S}$ \\
\hline & ADF- & Level & Constant & -8.10 & 0.62 & 78 & NS \\
\hline & Fisher & & Constant and trend & 7.59 & 0.67 & 78 & NS \\
\hline & Chi- & First & Constant & 33.52 & 0.00 & 74 & S \\
\hline & & Difference & Constant and trend & 25.97 & 0.00 & 72 & $\mathrm{~S}$ \\
\hline & PP-Fisher & Level & Constant & 6.93 & 0.73 & 80 & NS \\
\hline & Chi- & & Constant and trend & 5.01 & 0.89 & 80 & NS \\
\hline & squared & First & Constant & 33.48 & 0.00 & 75 & $\mathrm{~S}$ \\
\hline & & Difference & Constant and trend & 28.50 & 0.00 & 75 & $\mathrm{~S}$ \\
\hline & Breitung & Level & Constant & & & & \\
\hline & & & Constant and trend & -0.99 & 0.16 & 73 & NS \\
\hline & & First & Constant & & & & \\
\hline & & Difference & Constant and trend & -5.15 & 0.00 & 67 & $\mathrm{~S}$ \\
\hline & Hadri & Level & Constant & 2.41 & 0.01 & 85 & NS \\
\hline & Z-stat. & & Constant and trend & 2.53 & 0.01 & 85 & NS \\
\hline & & & Constant & 0.26 & 0.40 & 80 & $\mathrm{~S}$ \\
\hline & & Differ & $\operatorname{stan}$ & 1 & 0 & 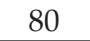 & NS \\
\hline
\end{tabular}




\begin{tabular}{|c|c|c|c|c|c|c|c|}
\hline Varijable & Metod & & $\begin{array}{l}\text { Deterministička } \\
\text { komponenta }\end{array}$ & Statistika & Verovatnoća* & $\begin{array}{l}\text { Broj } \\
\text { posm. }\end{array}$ & $\begin{array}{l}\text { Nestacionarnost } \\
\text { (NS) ili } \\
\text { stacionarnost (S) }\end{array}$ \\
\hline \multirow[t]{24}{*}{ DC } & \multirow[t]{4}{*}{ LLC } & \multirow[t]{2}{*}{ Nivo } & Konstanta & $-3,33$ & 0,00 & 76 & $S$ \\
\hline & & & Konstanta i trend & $-1,17$ & 0,12 & 77 & NS \\
\hline & & \multirow{2}{*}{$\begin{array}{l}\text { Prva } \\
\text { diferenca }\end{array}$} & Konstanta & $-0,94$ & 0,17 & 74 & NS \\
\hline & & & Konstanta i trend & $-2,22$ & 0,01 & 74 & $S$ \\
\hline & \multirow{4}{*}{$\begin{array}{l}\text { IPS W - } \\
\text { stat. }\end{array}$} & \multirow[t]{2}{*}{ Nivo } & Konstanta & $-1,63$ & 0,05 & 76 & $S$ \\
\hline & & & Konstanta i trend & 2,84 & 0,99 & 77 & NS \\
\hline & & \multirow{2}{*}{$\begin{array}{l}\text { Prva } \\
\text { diferenca }\end{array}$} & Konstanta & 0,10 & 0,54 & 74 & NS \\
\hline & & & Konstanta i trend & $-0,74$ & 0,23 & 74 & NS \\
\hline & \multirow{4}{*}{$\begin{array}{l}\text { ADF- } \\
\text { Fisher } \\
\text { Chi- } \\
\text { squared }\end{array}$} & \multirow{2}{*}{ Nivo } & Konstanta & 17,00 & 0,07 & 76 & NS \\
\hline & & & Konstanta i trend & 5,61 & 0,85 & 77 & NS \\
\hline & & \multirow{2}{*}{$\begin{array}{l}\text { Prva } \\
\text { diferenca }\end{array}$} & Konstanta & 8,00 & 0,63 & 74 & NS \\
\hline & & & Konstanta i trend & 11,76 & 0,30 & 74 & NS \\
\hline & \multirow{4}{*}{$\begin{array}{l}\text { PP-Fisher } \\
\text { Chi- } \\
\text { squared }\end{array}$} & \multirow[t]{2}{*}{ Nivo } & Konstanta & 6,72 & 0,75 & 80 & NS \\
\hline & & & Konstanta i trend & 0,29 & 1,00 & 80 & NS \\
\hline & & \multirow{2}{*}{$\begin{array}{l}\text { Prva } \\
\text { diferenca }\end{array}$} & Konstanta & 7,38 & 0,68 & 75 & NS \\
\hline & & & Konstanta i trend & 10,33 & 0,41 & 75 & NS \\
\hline & \multirow[t]{4}{*}{ Breitung } & \multirow[t]{2}{*}{ Nivo } & Konstanta & & & & \\
\hline & & & Konstanta i trend & 1,64 & 0,95 & 72 & NS \\
\hline & & \multirow{2}{*}{$\begin{array}{l}\text { Prva } \\
\text { diferenca }\end{array}$} & Konstanta & & & & \\
\hline & & & Konstanta i trend & $-17,36$ & 0,04 & 69 & $S$ \\
\hline & \multirow{4}{*}{$\begin{array}{l}\text { Hadri } \\
\text { Z-stat. }\end{array}$} & \multirow[t]{2}{*}{ Nivo } & Konstanta & 1,62 & 0,05 & 85 & NS \\
\hline & & & Konstanta i trend & 5,64 & 0,00 & 85 & NS \\
\hline & & \multirow{2}{*}{\begin{tabular}{|l|} 
Prva \\
diferenca
\end{tabular}} & Konstanta & 3,57 & 0,00 & 80 & NS \\
\hline & & & Konstanta i trend & 1,86 & 0,03 & 80 & NS \\
\hline \multirow[t]{24}{*}{ REM } & \multirow[t]{4}{*}{ LLC } & Nivo & Konstanta & $-0,47$ & 0,32 & 84 & NS \\
\hline & & & Konstanta i trend & $-0,57$ & 0,29 & 78 & NS \\
\hline & & Prva & Konstanta & $-4,94$ & 0,00 & 80 & $S$ \\
\hline & & diferenca & Konstanta i trend & $-4,31$ & 0,00 & 80 & $S$ \\
\hline & IPS W - & Nivo & Konstanta & 0,47 & 0,68 & 84 & NS \\
\hline & stat. & & Konstanta i trend & $-1,98$ & 0,02 & 78 & $\mathrm{~S}$ \\
\hline & & Prva & Konstanta & $-5,21$ & 0,00 & 80 & $S$ \\
\hline & & diferenca & Konstanta i trend & $-3,90$ & 0,00 & 80 & $\mathrm{~S}$ \\
\hline & ADF- & Nivo & Konstanta & 10,58 & 0,39 & 84 & NS \\
\hline & Fisher & & Konstanta i trend & 18,51 & 0,05 & 78 & $S$ \\
\hline & Chi- & Prva & Konstanta & 43,33 & 0,00 & 80 & $S$ \\
\hline & squared & diferenca & Konstanta i trend & 32,21 & 0,00 & 80 & $S$ \\
\hline & PP-Fisher & Nivo & Konstanta & 11,08 & 0,35 & 85 & NS \\
\hline & Chi- & & Konstanta i trend & 9,83 & 0,46 & 85 & NS \\
\hline & squared & Prva & Konstanta & 41,75 & 0,00 & 80 & $\mathrm{~S}$ \\
\hline & & diferenca & Konstanta i trend & 30,84 & 0,00 & 80 & $S$ \\
\hline & Breitung & Nivo & Konstanta & & & & \\
\hline & & & Konstanta i trend & $-1,46$ & 0,07 & 73 & NS \\
\hline & & Prva & Konstanta & & & & \\
\hline & & diferenca & Konstanta i trend & $-3,61$ & 0,02 & 75 & $\mathrm{~S}$ \\
\hline & Hadri & Nivo & Konstanta & 6,18 & 0,00 & 90 & NS \\
\hline & Z-stat. & & Konstanta i trend & 2,05 & 0,02 & 90 & NS \\
\hline & & Prva & Konstanta & 0,97 & 0,17 & 85 & $\mathrm{~S}$ \\
\hline & & diferenca & Konstanta i trend & 1,72 & 0,04 & 85 & $S$ \\
\hline
\end{tabular}




\begin{tabular}{|c|c|c|c|c|c|c|c|}
\hline Variable & Method & & $\begin{array}{l}\text { Deterministic } \\
\text { terms }\end{array}$ & Statistics & Prob.* & Obs. & $\begin{array}{l}\text { Non Stationary } \\
\text { (NS) Stationary } \\
\text { (S) }\end{array}$ \\
\hline \multirow[t]{24}{*}{ DC } & \multirow[t]{4}{*}{ LLC } & \multirow[t]{2}{*}{ Level } & Constant & -3.33 & 0.00 & 76 & $\mathrm{~S}$ \\
\hline & & & Constant and trend & -1.17 & 0.12 & 77 & NS \\
\hline & & \multirow{2}{*}{$\begin{array}{l}\text { First } \\
\text { Difference }\end{array}$} & Constant & -0.94 & 0.17 & 74 & NS \\
\hline & & & Constant and trend & -2.22 & 0.01 & 74 & $\mathrm{~S}$ \\
\hline & \multirow{4}{*}{$\begin{array}{l}\text { IPS W - } \\
\text { stat. }\end{array}$} & \multirow[t]{2}{*}{ Level } & Constant & -1.63 & 0.05 & 76 & $\mathrm{~S}$ \\
\hline & & & Constant and trend & 2.84 & 0.99 & 77 & NS \\
\hline & & \multirow{2}{*}{$\begin{array}{l}\text { First } \\
\text { Difference }\end{array}$} & Constant & 0.10 & 0.54 & 74 & NS \\
\hline & & & Constant and trend & -0.74 & 0.23 & 74 & NS \\
\hline & \multirow{4}{*}{$\begin{array}{l}\text { ADF- } \\
\text { Fisher } \\
\text { Chi- } \\
\text { squared }\end{array}$} & \multirow[t]{2}{*}{ Level } & Constant & 17.00 & 0.07 & 76 & NS \\
\hline & & & Constant and trend & 5.61 & 0.85 & 77 & NS \\
\hline & & \multirow{2}{*}{$\begin{array}{l}\text { First } \\
\text { Difference }\end{array}$} & Constant & 8.00 & 0.63 & 74 & NS \\
\hline & & & Constant and trend & 11.76 & 0.30 & 74 & NS \\
\hline & \multirow{4}{*}{$\begin{array}{l}\text { PP-Fisher } \\
\text { Chi- } \\
\text { squared }\end{array}$} & \multirow[t]{2}{*}{ Level } & Constant & 6.72 & 0.75 & 80 & NS \\
\hline & & & Constant and trend & 0.29 & 1.00 & 80 & NS \\
\hline & & \multirow{2}{*}{\begin{tabular}{l|} 
First \\
Difference
\end{tabular}} & Constant & 7.38 & 0.68 & 75 & NS \\
\hline & & & Constant and trend & 10.33 & 0.41 & 75 & NS \\
\hline & \multirow[t]{4}{*}{ Breitung } & \multirow[t]{2}{*}{ Level } & Constant & & & & \\
\hline & & & Constant and trend & 1.64 & 0.95 & 72 & NS \\
\hline & & \multirow{2}{*}{$\begin{array}{l}\text { First } \\
\text { Difference }\end{array}$} & Constant & & & & \\
\hline & & & Constant and trend & -17.36 & 0.04 & 69 & $\mathrm{~S}$ \\
\hline & \multirow{4}{*}{$\begin{array}{l}\text { Hadri } \\
\text { Z-stat. }\end{array}$} & \multirow[t]{2}{*}{ Level } & Constant & 1.62 & 0.05 & 85 & NS \\
\hline & & & Constant and trend & 5.64 & 0.00 & 85 & NS \\
\hline & & \multirow{2}{*}{$\begin{array}{l}\text { First } \\
\text { Difference }\end{array}$} & Constant & 3.57 & 0.00 & 80 & NS \\
\hline & & & Constant and trend & 1.86 & 0.03 & 80 & NS \\
\hline \multirow[t]{24}{*}{ REM } & \multirow[t]{4}{*}{ LLC } & Level & Constant & -0.47 & 0.32 & 84 & NS \\
\hline & & & Constant and trend & -0.57 & 0.29 & 78 & NS \\
\hline & & & Constant & -4.94 & 0.00 & 80 & $\mathrm{~S}$ \\
\hline & & Difference & Constant and trend & -4.31 & 0.00 & 80 & $\mathrm{~S}$ \\
\hline & IPS W - & Level & Constant & 0.47 & 0.68 & 84 & NS \\
\hline & & & Constant and trend & -1.98 & 0.02 & 78 & $S$ \\
\hline & & First & Constant & -5.21 & 0.00 & 80 & $\mathrm{~S}$ \\
\hline & & Difference & Constant and trend & -3.90 & 0.00 & 80 & $\mathrm{~S}$ \\
\hline & ADF- & Level & Constant & 10.58 & 0.39 & 84 & NS \\
\hline & Fisher & & Constant and trend & 18.51 & 0.05 & 78 & $\mathrm{~S}$ \\
\hline & Chi- & First & Constant & 43.33 & 0.00 & 80 & $\mathrm{~S}$ \\
\hline & squared & Difference & Constant and trend & 32.21 & 0.00 & 80 & $\mathrm{~S}$ \\
\hline & PP-Fisher & Level & Constant & 11.08 & 0.35 & 85 & NS \\
\hline & Chi- & & Constant and trend & 9.83 & 0.46 & 85 & NS \\
\hline & squared & First & Constant & 41.75 & 0.00 & 80 & $\mathrm{~S}$ \\
\hline & & Difference & Constant and trend & 30.84 & 0.00 & 80 & $\mathrm{~S}$ \\
\hline & Breitung & Level & Constant & & & & \\
\hline & & & Constant and trend & -1.46 & 0.07 & 73 & NS \\
\hline & & First & Constant & & & & \\
\hline & & Difference & Constant and trend & -3.61 & 0.02 & 75 & $S$ \\
\hline & Hadri & Level & Constant & 6.18 & 0.00 & 90 & NS \\
\hline & Z-stat. & & Constant and trend & 2.05 & 0.02 & 90 & NS \\
\hline & & First & Constant & 0.97 & 0.17 & 85 & $\mathrm{~S}$ \\
\hline & & Difference & Constant and trend & 1.72 & 0.04 & 85 & $\mathrm{~S}$ \\
\hline
\end{tabular}




\begin{tabular}{|c|c|c|c|c|c|c|c|}
\hline Varijable & Metod & & $\begin{array}{l}\text { Deterministička } \\
\text { komponenta }\end{array}$ & Statistika & Verovatnoća* & $\begin{array}{l}\text { Broj } \\
\text { posm. }\end{array}$ & $\begin{array}{l}\text { Nestacionarnost } \\
\text { (NS) ili } \\
\text { stacionarnost (S) }\end{array}$ \\
\hline \multirow{24}{*}{ REGULAT } & \multirow[t]{4}{*}{ LLC } & \multirow[t]{2}{*}{ Nivo } & Konstanta & $-0,53$ & 0,30 & 72 & NS \\
\hline & & & Konstanta i trend & $-3,29$ & 0,00 & 72 & $S$ \\
\hline & & \multirow{2}{*}{$\begin{array}{l}\text { Prva } \\
\text { diferenca }\end{array}$} & Konstanta & $-8,48$ & 0,00 & 68 & $S$ \\
\hline & & & Konstanta i trend & $-5,56$ & 0,00 & 67 & $S$ \\
\hline & \multirow{4}{*}{$\begin{array}{l}\text { IPS W - } \\
\text { stat. }\end{array}$} & \multirow[t]{2}{*}{ Nivo } & Konstanta & $-0,10$ & 0,46 & 72 & NS \\
\hline & & & Konstanta i trend & $-2,36$ & 0,01 & 72 & $S$ \\
\hline & & \multirow{2}{*}{$\begin{array}{l}\text { Prva } \\
\text { diferenca }\end{array}$} & Konstanta & $-6,70$ & 0,00 & 68 & $S$ \\
\hline & & & Konstanta i trend & $-4,86$ & 0,00 & 67 & $S$ \\
\hline & \multirow{4}{*}{\begin{tabular}{|l|} 
ADF- \\
Fisher \\
Chi- \\
squared
\end{tabular}} & \multirow[t]{2}{*}{ Nivo } & Konstanta & 13,16 & 0,21 & 72 & NS \\
\hline & & & Konstanta i trend & 23,04 & 0,01 & 72 & $S$ \\
\hline & & \multirow{2}{*}{\begin{tabular}{|l} 
Prva \\
diferenca
\end{tabular}} & Konstanta & 56,39 & 0,00 & 68 & $S$ \\
\hline & & & Konstanta i trend & 38,56 & 0,00 & 67 & $\mathrm{~S}$ \\
\hline & \multirow{4}{*}{$\begin{array}{l}\text { PP-Fisher } \\
\text { Chi- } \\
\text { squared }\end{array}$} & \multirow[t]{2}{*}{ Nivo } & Konstanta & 6,53 & 0,77 & 75 & NS \\
\hline & & & Konstanta i trend & 15,18 & 0,13 & 75 & NS \\
\hline & & \multirow{2}{*}{\begin{tabular}{|l|} 
Prva \\
diferenca
\end{tabular}} & Konstanta & 73,09 & 0,00 & 70 & $S$ \\
\hline & & & Konstanta i trend & 63,91 & 0,00 & 80 & $\mathrm{~S}$ \\
\hline & \multirow[t]{4}{*}{ Breitung } & \multirow[t]{2}{*}{ Nivo } & Konstanta & & & & \\
\hline & & & Konstanta i trend & $-2,26$ & 0,01 & 67 & $S$ \\
\hline & & \multirow{2}{*}{$\begin{array}{l}\text { Prva } \\
\text { diferenca }\end{array}$} & Konstanta & & & & \\
\hline & & & Konstanta i trend & $-2,77$ & 0,00 & 62 & $S$ \\
\hline & \multirow{4}{*}{$\begin{array}{l}\text { Hadri } \\
\text { Z-stat. }\end{array}$} & \multirow[t]{2}{*}{ Nivo } & Konstanta & 4,43 & 0,00 & 85 & NS \\
\hline & & & Konstanta i trend & 2,24 & 0,01 & 85 & NS \\
\hline & & \multirow{2}{*}{$\begin{array}{l}\text { Prva } \\
\text { diferenca }\end{array}$} & Konstanta & $-0,71$ & 0,76 & 75 & $S$ \\
\hline & & & Konstanta i trend & 2,93 & 0,00 & 75 & NS \\
\hline \multirow[t]{24}{*}{ GAP } & \multirow[t]{4}{*}{ LLC } & Nivo & Konstanta & $-1,79$ & 0,04 & 82 & $S$ \\
\hline & & & Konstanta i trend & $-0,30$ & 0,38 & 82 & NS \\
\hline & & & Konstanta & $-3,30$ & 0,00 & 79 & $\mathrm{~S}$ \\
\hline & & diferenca & Konstanta i trend & $-2,82$ & 0,00 & 79 & $S$ \\
\hline & IPS W - & Nivo & Konstanta & $-0,84$ & 0,20 & 82 & NS \\
\hline & stat. & & Konstanta i trend & $-0,06$ & 0,48 & 82 & NS \\
\hline & & Prva & Konstanta & $-2,64$ & 0,00 & 79 & $S$ \\
\hline & & diferenca & Konstanta i trend & $-1,02$ & 0,15 & 79 & NS \\
\hline & ADF- & Nivo & Konstanta & 11,10 & 0,35 & 82 & NS \\
\hline & Fisher & & Konstanta i trend & 8,14 & 0,62 & 82 & NS \\
\hline & Chi- & Prva & Konstanta & 23,78 & 0,01 & 79 & $S$ \\
\hline & squared & diferenca & Konstanta i trend & 14,22 & 0,16 & 79 & NS \\
\hline & PP-Fisher & Nivo & Konstanta & 6,98 & 0,73 & 85 & NS \\
\hline & Chi- & & Konstanta i trend & 3,94 & 0,95 & 85 & NS \\
\hline & squared & Prva & Konstanta & 28,17 & 0,00 & 80 & $\mathrm{~S}$ \\
\hline & & diferenca & Konstanta i trend & 16,84 & 0,08 & 80 & NS \\
\hline & Breitung & Nivo & Konstanta & & & & \\
\hline & & & Konstanta i trend & $-0,94$ & 0,17 & 77 & NS \\
\hline & & Prva & Konstanta & & & & \\
\hline & & diferenca & Konstanta i trend & $-2,69$ & 0,00 & 74 & $S$ \\
\hline & Hadri & Nivo & Konstanta & 3,27 & 0,00 & 90 & NS \\
\hline & Z-stat. & & Konstanta i trend & 1,62 & 0,05 & 90 & NS \\
\hline & & Prva & Konstanta & $-0,52$ & 0,69 & 85 & $S$ \\
\hline & & diferenca & Konstanta i trend & 2,79 & 0,00 & 85 & NS \\
\hline
\end{tabular}

Napomena: Oznake u tabeli su: LLC- Levin-Lin-Chu test; IPS za Im-Pesaran-Shin test. S - Stacionarnost, NS - nestacionarnost. *Verovatnoća za Fisher testove dobijena je kao asimptotska Hi kvadrat raspodela. Svi ostali testovi imaju asimptotski normalnu raspodelu. Nulta hipoteza za sve testove (izuzetak je Hadri test) je da postoji jedinični koren, astenativna hipoteza je da je promenljiva stacionarna. Nulta hipoteza za Hadri test je da ne postoji jedinični koren, alternativna je da postoji. Nivo značajnosti je $5 \%$. Svuda gde je to bilo potrebno, docnja je automatski određena pomoću Schwarz informacionog kriterijuma sa maksimalno dve docnje, spektralna analiza se zasniva na Bartlett. Kao determinističke komponente koriste se individualni efekti, kao i individualni efekti i individualni trend. U pitanju je nebalansirani panel. Za ocene testova korišćen je softver EViews 10.

Izvor: Proračun autora. 


\begin{tabular}{|c|c|c|c|c|c|c|c|}
\hline Variable & Method & & $\begin{array}{l}\text { Deterministic } \\
\text { terms }\end{array}$ & Statistics & Prob.* & Obs. & $\begin{array}{c}\text { Non Stationary } \\
\text { (NS) Stationary } \\
\text { (S) }\end{array}$ \\
\hline \multirow[t]{24}{*}{ REGULAT } & \multirow[t]{4}{*}{ LLC } & \multirow[t]{2}{*}{ Level } & Constant & -0.53 & 0.30 & 72 & NS \\
\hline & & & Constant and trend & -3.29 & 0.00 & 72 & $\mathrm{~S}$ \\
\hline & & \multirow{2}{*}{$\begin{array}{l}\text { First } \\
\text { Difference }\end{array}$} & Constant & -8.48 & 0.00 & 68 & $\mathrm{~S}$ \\
\hline & & & Constant and trend & -5.56 & 0.00 & 67 & $\mathrm{~S}$ \\
\hline & \multirow{4}{*}{$\begin{array}{l}\text { IPS W - } \\
\text { stat. }\end{array}$} & \multirow[t]{2}{*}{ Level } & Constant & -0.10 & 0.46 & 72 & NS \\
\hline & & & Constant and trend & -2.36 & 0.01 & 72 & $\mathrm{~S}$ \\
\hline & & \multirow{2}{*}{$\begin{array}{l}\text { First } \\
\text { Difference }\end{array}$} & Constant & -6.70 & 0.00 & 68 & $\mathrm{~S}$ \\
\hline & & & Constant and trend & -4.86 & 0.00 & 67 & $\mathrm{~S}$ \\
\hline & \multirow{4}{*}{$\begin{array}{l}\text { ADF- } \\
\text { Fisher } \\
\text { Chi- } \\
\text { squared }\end{array}$} & \multirow[t]{2}{*}{ Level } & Constant & 13.16 & 0.21 & 72 & NS \\
\hline & & & Constant and trend & 23.04 & 0.01 & 72 & $\mathrm{~S}$ \\
\hline & & \multirow{2}{*}{$\begin{array}{l}\text { First } \\
\text { Difference }\end{array}$} & Constant & 56.39 & 0.00 & 68 & $\mathrm{~S}$ \\
\hline & & & Constant and trend & 38.56 & 0.00 & 67 & $\mathrm{~S}$ \\
\hline & \multirow{4}{*}{$\begin{array}{l}\text { PP-Fisher } \\
\text { Chi- } \\
\text { squared }\end{array}$} & \multirow[t]{2}{*}{ Level } & Constant & 6.53 & 0.77 & 75 & NS \\
\hline & & & Constant and trend & 15.18 & 0.13 & 75 & NS \\
\hline & & \multirow{2}{*}{\begin{tabular}{|l|} 
First \\
Difference
\end{tabular}} & Constant & 73.09 & 0.00 & 70 & $\mathrm{~S}$ \\
\hline & & & Constant and trend & 63.91 & 0.00 & 80 & $\mathrm{~S}$ \\
\hline & \multirow{4}{*}{ Breitung } & \multirow[t]{2}{*}{ Level } & Constant & & & & \\
\hline & & & Constant and trend & -2.26 & 0.01 & 67 & $\mathrm{~S}$ \\
\hline & & \multirow{2}{*}{$\begin{array}{l}\text { First } \\
\text { Difference } \\
\end{array}$} & Constant & & & & \\
\hline & & & Constant and trend & -2.77 & 0.00 & 62 & $\mathrm{~S}$ \\
\hline & \multirow{4}{*}{$\begin{array}{l}\text { Hadri } \\
\text { Z-stat. }\end{array}$} & \multirow[t]{2}{*}{ Level } & Constant & 4.43 & 0.00 & 85 & NS \\
\hline & & & Constant and trend & 2.24 & 0.01 & 85 & NS \\
\hline & & \multirow{2}{*}{$\begin{array}{l}\text { First } \\
\text { Difference }\end{array}$} & Constant & -0.71 & 0.76 & 75 & $\mathrm{~S}$ \\
\hline & & & Constant and trend & 2.93 & 0.00 & 75 & NS \\
\hline \multirow[t]{24}{*}{ GAP } & \multirow[t]{4}{*}{ LLC } & Level & Constant & -1.79 & 0.04 & 82 & $\mathrm{~S}$ \\
\hline & & & Constant and trend & -0.30 & 0.38 & 82 & NS \\
\hline & & & Constant & -3.30 & 0.00 & 79 & $\mathrm{~S}$ \\
\hline & & Difference & Constant and trend & -2.82 & 0.00 & 79 & $\mathrm{~S}$ \\
\hline & IPS W - & Level & Constant & -0.84 & 0.20 & 82 & NS \\
\hline & & & Constant and trend & -0.06 & 0.48 & 82 & NS \\
\hline & & First & Constant & -2.64 & 0.00 & 79 & $\mathrm{~S}$ \\
\hline & & Difference & Constant and trend & -1.02 & 0.15 & 79 & NS \\
\hline & ADF- & Level & Constant & 11.10 & 0.35 & 82 & NS \\
\hline & Fisher & & Constant and trend & 8.14 & 0.62 & 82 & NS \\
\hline & Chi- & First & Constant & 23.78 & 0.01 & 79 & $\mathrm{~S}$ \\
\hline & squared & Difference & Constant and trend & 14.22 & 0.16 & 79 & NS \\
\hline & PP-Fisher & Level & Constant & 6.98 & 0.73 & 85 & NS \\
\hline & Chi- & & Constant and trend & 3.94 & 0.95 & 85 & NS \\
\hline & squared & First & Constant & 28.17 & 0.00 & 80 & $\mathrm{~S}$ \\
\hline & & Difference & Constant and trend & 16.84 & 0.08 & 80 & NS \\
\hline & Breitung & Level & Constant & & & & \\
\hline & & & Constant and trend & -0.94 & 0.17 & 77 & NS \\
\hline & & First & Constant & & & & \\
\hline & & Difference & Constant and trend & -2.69 & 0.00 & 74 & $\mathrm{~S}$ \\
\hline & Hadri & Level & Constant & 3.27 & 0.00 & 90 & NS \\
\hline & Z-stat. & & Constant and trend & 1.62 & 0.05 & 90 & NS \\
\hline & & First & Constant & -0.52 & 0.69 & 85 & $\mathrm{~S}$ \\
\hline & & Difference & Constant and trend & 2.79 & 0.00 & 85 & NS \\
\hline
\end{tabular}

Note: The labels in the table are: LLC-Levin-Lin-Chu test; IPS for the Im-Pesaran-Shin test. S - Stationary, NS - Non-stationary.

*The probability for Fisher tests was obtained as an asymptotic Chi-squared distribution. All other tests have an asymptotic normal distribution. The null hypothesis for all tests (except Hadri test) is that there is a unit root, while the alternative hypothesis is that the variable is stationary. The null hypothesis for the Hadri test is that there is no unit root, the alternative is that it exists. Significance level is $5 \%$. Wherever it was needed, the lag length was automatically determined using the Schwarz Information Criterion with a maximum of two lags, the kernel is based on Bartlett. Individual effects, as well as individual effects and individual trends, are used as deterministic components. It is an unbalanced panel. EViews 10 software was used for the test estimates.

Source: Authors' calculation. 


\section{Literatura / References}

1. Ahearne A. et al.(2007). Internal and External Current Account Balance in the Euro Area, Joint Bruegel, Korea Institute for International Economic Policy, and Peterson Institute for International Economics Workshop on "Policy to Reduce Global Imbalances".

2. Alcidi C. and D. Gros (2011). Adjustment Difficulties and Debt Overhangs in the Eurozone Periphery, CEPS Working Document 347, Centre for European Policy Studies.

3. Atoyan et al.(2013). Rebalancing: Evidence from Current Account Adjustment in Europe, Working Paper 13/74, International Monetary Fund.

4. Baxa, J. and T. Olešňaník (2014). Current accounts in the eurozone countries: The role of euro, fiscal policies and financial developments, IES Working Paper, No. 27/2014. http://hdl. handle.net/10419/120425

5. Belke, A. and C. Dreger (2013). "Current Account Imbalances in the Euro Area: Does Catching up Explain the Development?", Review of International Economics, 21(1) 6-17.

6. Berger, H., and V. Nitsch (2010). The Euro's Effect on Trade Imbalances, IMF Working Paper 10/226, International Monetary Fund.

7. Blanchard, O., and F. Giavazzi (2002). "Current Account Deficits in the Euro Area: The End of the Feldstein-Horioka Puzzle?", Brookings Papers on Economic Activity, 33(2), pp. 147-186.

8. Breitung, J. (2000). "The Local Power of Some Unit Root Tests for Panel Data", in B. Baltagi (ed.), Advances in Econometrics, Vol. 15: Nonstationary Panels, Panel Cointegration, and Dynamic Panels, Amsterdam: JAI Press, pp. 161-178.

9. Cesaroni, T. and R. De Santis (2015). Current account 'Core-periphery dualism' in the EMU, LEQS Paper No. 90/2015.

10. Chinn, M. and H. Ito (2008)." A New Measure of Financial Openness", Journal of Comparative Policy Analysis, 10(3) (September), pp. 309 - 322

11. Choi, I. (2001). "Unit Root Tests for Panel Data", Journal of International Money and Finance 22, pp. 249-272.
12. Comunale, M. and J. Hessel (2014). Current account imbalances in the Euro area: competitiveness or financial cycle?, DNB Working Paper, No. 443/ October, pp.1-46. http://www.dnb.nl/binaries/Working\%20 Paper\%20443_tcm46-313481.pdf

13. Dickey, D.A. and W.A. Fuller (1979). "Distribution of the Estimators for Autoregressive Time Series with a Unit Root", Journal of the American Statistical Association, 74(366), pp. 427-431.

14. Gibson, H. D. et all (2014). "The Crisis in the Euro Area: An Analytic Overview", Journal of Macroeconomics 39, pp. 233-239. DOI: 10.1016/j.jmacro.2013.09.014

15. Hadri, K. (2000). "Testing for Stationarity in Heterogeneous Panel Data", Econometric Journal, 3(2), pp. 148-161.

16. Hlouskova, J. and M. Wagner (2006). "The Performance of Panel Unit Root and Stationarity Tests: Results from a Large Scale Simulation Study", Econometric Review 25(1), pp. 85-116.

17. Holinski, K. et al. (2012). "Persistent Macroeconomic Imbalances in the Euro Area: Causes and Consequences", Federal Reserve Bank of St. Louis Review, 94(1), pp. 1-20.

18. Im, K.S. et al. (2003). "Testing for unit roots in heterogeneous panels", Journal of Econometrics 115 (1), pp. 53-74.

19. Jaromír, B. and T. Olešňaník (2014). Current Accounts in the Eurozone Countries: The Role of Euro, Fiscal Policies and Financial Developments, Institute of Economic Studies, Faculty of Social Sciences Charles University in Prague, IES Working Paper: 27/2014.

20. Jaumotte, F. and P. Sodsriwiboon (2010). "Current Account Imbalances in the Southern Euro Area", IMF WP/10/139.

21. Johansen, S (1991). "Estimation and Hypothesis Testing of Cointegration Vectors in Gaussian Vector Autoregressive Models", Econometrica, 59(6), pp. 1551-1580.

22. Kao, C. (1999). "Spurious Regression and Residual-Based Tests for Cointegration in Panel Data", Journal of Econometrics 90 (1), pp. 1-44. 
23. Kentsch, S. (2010). The Current Account Imbalance between the North and the South of the EU, Maastricht University.

24. Kwiatkowski, D. et al (1992). “Testing the null hypothesis of stationarity against the alternative of a unit root: How sure are we that economic time series have a unit root?", Journal of Econometrics, 54(1-3) (October-December), pp. 159-178.

25. Levin, A. et al. (2002). "Unit root tests in panel data: asymptotic and finite sample properties", Journal of Econometrics 108(1), pp. $1-24$

26. Maddala, G.S. and S. Wu (1999). "A Comparative Study of Panel Data Unit Root Tests and a New Simple Test", Oxford Bulletin of Economics and Statistics, Special Issue, 0305-9049.

27. Mendoza, E.G. et al. (2009), "Financial Integration, Financial Development, and Global Imbalances", Journal of Political Economy, 117(3), pp. 371-416, doi: https:// doi.org/10.1086/599706.

28. Merler, S. and J. Pisani-Ferry (2012). The simple Macroeconomics of North and South in EMU. Bruegel Working Paper 2012/12.

29. Pedroni, P. (1999). “Critical Values for Cointegration Tests in Heterogeneous Panels with Multiple Regressors", Oxford Bulletin of Economics and Statistics 61(0), pp. 653-670.
30. Phillips, P.C.B. and B.E. Hansen (1990). "Statistical Inference in Instrumental Variables Regression with I(1) Processes", Review of Economics Studies, 57, pp. 99-125.

31. Pisani-Ferry, J. (2013). "The known unknowns and unknown unknowns of the European Monetary Union", Journal of International Money and Finance 34, pp. 6-14.

32. Sanchez J.L.D. and A. Varoudakis (2013). Growth and Competitiveness as Factors of Eurozone External Imbalances: Evidence and Policy Implications, World Bank Policy Research Working Paper Series no.6732.

33. Schmitz, B., and J. von Hagen (2011). "Current Account Imbalances and Financial Integration in the Euro Area", Journal of International Money and Finance, 30 (8), pp. 1676-1695. DOI: 10.1016/j. jimonfin.2011.08.003

34. Schnabl, G. and T. Wollmershäuser (2013). Fiscal Divergence and Current Account Imbalances in Europe, Working Paper 4108, CESifo - Center for Economic Studies Ifo Institute.

35. Unger, R. (2016). Asymmetric Credit Growth and Current Account Imbalances in the Euro Area, FIW Working Paper $N^{\circ} 166$, February. 